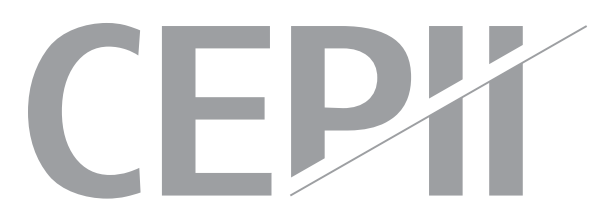

\title{
Making (Small) Firms Happy. The Heterogeneous Effect of Trade Facilitation Measures
}

\author{
Lionel Fontagné, Gianluca Orefice \& Roberta Piermartini
}

\section{Highlights}

- The Trade Facilitation Agreement will have asymmetric effect on heterogeneous exporters.

- We merge French customs data with a new database of Trade Facilitation Indicators released recently by the OECD.

- Better information availability, advance ruling and appeal procedures mainly benefit small firms.

- The simplification of documents and automation tend to favor large firms.

- One explanation is that trade facilitation reduces the scope for corruption at borders, to the benefit of large firms. 


\section{Abstract}

This paper considers the asymmetric effect of Trade Facilitation Agreement (TFA) policies on heterogeneous exporters, based on matching a detailed panel of French firm exports to a new database of Trade Facilitation Indicators (TFIs) released recently by the Organisation for Economic Cooperation and Development (OECD). We analyze the effect of these TFls on three trade-related outcomes: (i) exported value (firm intensive margin), (ii) number of products exported (product extensive margin) and (iii) average export value per product exported (product intensive margin). We find strong evidence of a heterogeneous effect of trade facilitation across firm size. While better information availability, advance ruling and appeal procedures mainly benefit small firms, the simplification of documents and automation tend to favor large firms' trade. This is coherent with the idea that while some elements of the TFA simply reduce the fixed cost of exporting (favoring small firms in particular), other chapters in the TFA reduce the scope for corruption at borders, making large firms less reluctant to serve corrupt countries.

\section{Keywords}

Trade Facilitation, Heterogeneous Firms, Extensive Margin, Intensive Margin.

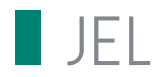

F13, F14.

\section{Working Paper}

\section{CEPI}

CEPII (Centre d'Etudes Prospectives et d'Informations Internationales) is a French institute dedicated to producing independent, policyoriented economic research helpful to understand the international economic environment and challenges in the areas of trade policy, competitiveness, macroeconomics, international finance and growth
CEPII Working Paper

Contributing to research in international economics

C C CEPII, PARIS, 2016

All rights reserved. Opinions expressed in this publication are those of the author(s) alone.

$\begin{array}{ll}\text { Editorial Director: } & \text { CEPII } \\ \text { Sébastien Jean } & \begin{array}{l}113, \text { rue de Grenelle } \\ 75007 \text { Paris }\end{array} \\ \text { Production: } & +33153685500 \\ \text { Laure Boivin } & \text { www.cepii.fr } \\ \text { No ISSN: } 1293-2574 & \text { Press contact: presse@ }\end{array}$




\section{Making (Small) Firms Happy.}

\section{The Heterogeneous Effect of Trade Facilitation Measures ${ }^{1}$}

Lionel Fontagné*

and

Gianluca Orefice ${ }^{\dagger}$

and

Roberta Piermartini $\ddagger$

\section{Introduction}

Exporting is a difficult business, and even more so for small firms. Successful exporting firstly implies a good knowledge and understanding of the destination country's rules and regulations. Lack of knowledge about regulations can result in the product not complying with the importing country's regulations, and can result in the firm facing the costs of rejection at the border of the targeted country. The exporter is required to supply the correct documentation, comply with customs procedures, and be subject to clearance and inspections. Hence, in addition to the cost of acquiring information about the rules and regulations in the destination market, which is product-destination specific, there are the costs in terms of time and uncertainty of delivery linked to the import/export procedure.

\footnotetext{
${ }^{1}$ We are grateful to Houssein Guimbard for providing tariff data at the country-product level, to Evdokia Möisé for providing the OECD Trade Facilitation Indicators and to Sophie Hatte for NGO data. Without implicating them, we thank Sébastien Jean, Lorenzo Rotunno, Farid Toubal and participants in the ETSG Conference 2015, and seminars held at University College Dublin, University of Paris 1 Panthéon-Sorbonne, GTDW in Geneva, CEPII in Paris, and SS St'Anna in Pise for comments and suggestions. The views expressed in this article are those of the authors and do not reflect those of the World Trade Organization. They are not meant to represent the positions or opinions of the WTO or its members, and are without prejudice to members' rights and obligations in the WTO

*PSE - Université Paris I and CEPII, (lionel.fontagne@univ-paris1.fr)

${ }^{\dagger}$ CEPII, (gianluca.orefice@cepii.fr)

‡ERSD, WTO, (roberta. piermartini@wto.org)
} 
Lengthy shipping times (including long delays at the border) can imply depreciation costs such as literal spoilage and technological obsolescence, for example in the case of consumer electronics (see Hummels and Schaur (2013)). ${ }^{2}$ These costs are sizable and are frequently complained about in surveys of exporters: cumbersome and lengthy administrative procedures at home and abroad cumulate. Small exporters that lack specialized teams and international operations departments, and ship infrequently or in small batches are particularly exposed to such costs. Also, we know from the empirical literature that small exporters are generally less efficient.

Given the fairly widespread phasing out of tariffs worldwide, these administrative costs are becoming a major hurdle. Delays in getting goods from origin to destination hinder exports more than do foreign tariffs. The average tariff applied to imports by Sub-Saharan Africa is $11.2 \%$, whereas the tariff equivalent for delay cost is $25.6 \% .^{3}$ Of these costs, the highest portion is due to administration. ${ }^{4}$ Hornok and Koren (2015) using Spanish shipment-level export data, show that a 50\% reduction in per-shipment administrative costs corresponds to a 9 percentage points reduction in the tariff. If there are fixed costs for accessing a new market, or indivisibility in terms of the administrative details to be completed, small and large exporters will be affected differently by these obstacles.

Reducing these costs falls under the agenda of "facilitating trade" as opposed to "liberalizing trade" (tariff cuts). The Trade Facilitation Agreement (TFA) concluded in Bali in December 2013 was aimed at reducing these costs by simplifying import/export procedures, sharing information, and promoting cooperation. Improved trade facilitation is likely to reduce both the variable and fixed trade costs of exporting but specific measures may have a greater effect on fixed costs than variable costs. Formalities, requirements, and customs procedures have to be met each time a shipment crosses a border, while information on border procedures is a one-time cost. Requiring countries to publish and make available information on border procedures, and to harmonize and simplify documentation requirements should reduce both

\footnotetext{
${ }^{2}$ Hummels and Schaur (2013) find that each day in transit is worth $0.6 \%$ to $2.1 \%$ of the value of the good.

${ }^{3}$ See Hummels (2007).

${ }^{4}$ Djankov et al. (2010) claim that $75 \%$ of delays to shipping containers between the origin and destination countries are is due to bureaucracy: customs procedures, tax procedures, clearance, and inspections.
} 
fixed and variable costs but perhaps through different provisions. Since trade facilitation provisions affect fixed and/or variable trade costs differently, it is important to disentangle the effect of different provisions on trade margins.

Economic theory suggests that the impact of various trade facilitation provisions may be bigger for small firms compared to large firms. In a standard heterogeneous firm model of trade with constant elasticity of substitution (CES) preferences, when the fixed costs of export decrease, this allows less productive firms to enter the export market since the lower fixed costs of exporting will be covered by their revenue (Melitz (2003) and Chaney (2008)). Thus, trade facilitation measures are expected to have a heterogeneous effect on the extensive margins of exporters depending on their initial productivity. However, this class of models predicts no differential effect on the intensive margin of individual exporters when the variable costs of trade fall. Departing from the classical CES preferences framework and allowing for firm-specific entry cost, Arkolakis (2010) predicts that when trade costs increase, trade shares are reallocated away from small firms because sales' elasticity with respect to variable trade costs is decreasing in firm size. Similarly, trade cost reductions will have an heterogeneous impact on the intensive margin of individual exporters, if one assumes that large firms are better able to bear the costs or face lower elasticity of substitution than small firms (Spearot, 2013). If this reasoning is correct, trade facilitation should make firms happy, and small firms even more so.

However, the analysis of the effect of trade facilitation on firms needs to take account of an additional element: the positive effect of trade facilitation on corruption. ${ }^{5}$ These indirect effects can change the balance among the gains from trade facilitation obtained by small and large firms, for two reasons. First, when entry costs are affected by corruption, big firms might benefit more than small firms from trade facilitation. Entry costs in secure and efficient destinations differ from those in highly corrupt countries since corruption represents

\footnotetext{
${ }^{5}$ Trade related corruption is correlated with time spent at customs Shepherd (2010a) shows that a $10 \%$ increase in trade time leads to a $14.5 \%$ fall in bilateral trade in less corrupt countries, and to a $15.3 \%$ fall in highly-corrupt countries. Trade-related corruption depends also on customs procedures; e.g. there is evidence that following establishment of the post-clearance audit (PCA) process, in the year 2010-11 Chinese Taipei customs were able to recover more than US\$26 million from evaded duties and fines (WTO, 2015).
} 
an additional entry cost. In an open economy, firms - but especially big players - will be more reluctant to enter corrupt foreign markets (Karpaty and Tingvall, 2015). ${ }^{6}$ Big firms are more visible and more sensitive to reputation effects, so the opportunity cost of being discovered by an NGO is higher for large compared to small firms (brand and reputation damages). ${ }^{7}$ Based on the above evidence, we expect large firms to be particularly reluctant to enter corrupt countries. Thus, elements of the TFA which reduce corruption at the border (such as simplification of documents and automation of procedures) should benefit big firms while reinforcing the competition faced by small firms. Second, the impact of corruption on trade costs at the border is ambiguous. Sequeira and Djankov (2014) show that bribes can act as a further trade cost or can help the firm to avoid a trade cost. Thus, the effect of trade facilitation on firms of different size is an empirical issue.

To address the heterogeneous effect of trade facilitation policies in destination markets on exporters of different sizes, we use detailed information on the trade facilitation measures adopted by importing countries (recently collected by the OECD), and information on the behavior (export participation, number of products exported, value of product-destination exports) of the universe of exporting firms from a country (French firm level trade information). By combining this information, we go beyond existing analyses of trade facilitation in terms of port efficiency and time to export, and overcome the usual limitations of survey-based analyses.

The OECD Trade Facilitation Indicators (TFIs) have been used in some recent studies to estimate the effect of TFA. Moïsé and Sorescu (2013) estimate that TFA can reduce overall trade costs by around $14 \%$ (within the range 9 to $24 \%$ across countries). In their estimation, the policy measures predicted to have the greatest impact in terms of trade cost reductions, are those that improve information availability, simplification and harmonization of documents, streamlining of procedures, and use of automated processes. Using the same index, Beverelli et al. (2015) find that TFA has significant export diversification effects, and

\footnotetext{
${ }^{6}$ Karpaty and Tingvall (2015) show that Swedish firms are less prone to export services to corrupt destinations, and that sensitivity to corruption is highest for large firms.

${ }^{7}$ Such mechanisms have been studied widely in the literature on corporate social responsibility (Baron, 2001) and there is evidence that large multinationals are sensitive to NGO activism (Harrison and Scorse, 2010).
} 
that measures aimed at improving information play an important role. ${ }^{8}$ Hillberry and Zhang (2015) are interested mainly in the effects of trade facilitation on the time required to import and export, and find that full implementation of the TFA can reduce the time spent in customs by 1.6 days for imports, and by 2 days for exports. In the context of individual trade facilitation provisions, they find that governance and automation are the reforms that provide the highest time savings. For example, governance accounts for $37 \%$ of the reduction in the time to import. Automation, which includes electronic documents exchange and application of risk management procedures, is responsible for about $30 \%$ of the reduction in time to import. However, these cost reductions are only averages across firms, and the expected impacts are not estimated based on firm size.

The distributional impact, by firm size, of reduced time to export is examined in Hoekman and Shepherd (2015) and Han and Piermartini (2016). Both papers use firm-level data for a range of developing countries taken from the World Bank's Enterprise Surveys database. Hoekman and Shepherd (2015) use the average time taken to export goods - as recorded by each firm - as an index of trade facilitation, and assess the differentiated impact of export time on the propensity to export by broad (micro, small, medium and large) exporting firm categories. While they find that the average export time is negatively associated with the percentage of sales that are exported directly, they do not find a differentiated impact across firms of different sizes. ${ }^{9}$ In a follow-up paper, Han and Piermartini (2016) show that, if the analysis includes both exporting and non-exporting firms, reducing time to export fosters exporting by small firms more than large firms, suggesting that this differential impact is driven mainly by the extensive margin. ${ }^{10}$

Against this background, our contribution is to examine how advances in several aspects of

\footnotetext{
${ }^{8}$ Beverelli et al. (2015) find that implementation of TFA would increase the number of products exported by Sub-Saharan African countries by $15.7 \%$.

${ }^{9}$ Indeed firm-level export time is likely to be endogenous to firms characteristics.

${ }^{10}$ Hoekman and Shepherd (2015) and Han and Piermartini (2016) acknowledge that these results might be biased by the questionable quality of the Enterprise Survey data, which are collected by private contractors with no enforcement power in the case of misstatement. Moreover, both these papers use export time as a measure of trade facilitation. However, this measure is based on export times as reported by individual firms which are determined by the perception of interviewees, and may depend on firm characteristics; they also do not vary across destination markets.
} 
the trade facilitation in the importing country affect exporters of different sizes. We do this by interacting detailed indicators of trade facilitation (information availability, advance rulings, appeal procedures, fees and charges, formalities, automated documentation and procedures, and border agency cooperation) with exporter size bins. Fernandes et al. (2015) also consider the importing country's trade facilitation measures and their impact on individual firms, but do not address the heterogenous effect of trade facilitation on firms of different size, which is the focus of our research. ${ }^{11}$ Other related papers in the literature, study the impact of trade facilitation measures adopted by the exporting country on its export performances. Martincus et al. (2015) provide the most convincing evidence of the impact of transit time at the exporting border on individual exporters' performance. ${ }^{12}$ Looking at the obstacles that exporters face in the destination market, partially addresses a potential problem of endogeneity and also is likely to capture more important trade costs. Indeed, the exporting firm faces administrative hurdles in all potential destination markets (such as the need to collect information on customs procedures and the cost of clearing paperwork). These costs are likely to be higher then those related to domestic procedures, which can be acquired once and for all.

The remainder of the paper is organized as follows. In section 2 we discuss details of the TFA in order to account only for measures that ultimately will be implemented. We show how the TFIs constructed by the OECD can (although partially) be mobilized for that purpose. Section 3 presents administrative data on the universe of French exporters to "reveal" the differentiated impact of the trade facilitation measures on firms of different sizes and capabilities. The estimation strategy is described in section 4 and section 5 provides a summary of the results. Section 6 concludes.

\footnotetext{
${ }^{11}$ Fernandes et al. (2015) examined the reduction in the number of physical inspections at the Albanian border, consecutive to the implementation of ASYCUDA. See below how ASYCUDA can affect customs procedures. Their objective is to establish a causal link of median time at the border on the values of imports at the firm-HS6-origin country level, using this experiment.

${ }^{12}$ Martincus et al. (2015) exploit transaction level export records at the Uruguayan border, for the period 20022011. Interestingly these data provide information on the length of transit procedures and the track used: "green" or "red" channel. They confirm that delays at the exporting border curb individual exports.
} 


\section{OECD Trade Facilitation Indicators (TFIs): Mapping specific measures of the TFA to trade costs reduction}

Most of the literature on the impact of trade facilitation uses measures of trade facilitation that are loosely related to TFA. Time to trade (actual number of days spent in transit, at customs, and at sea) is an outcome measure; it does not provide information on the potential impact of the specific policies to be implemented. Port efficiency, another proxy for trade facilitation (see Feenstra and Ma (2014)) ${ }^{13}$, is affected by factors other than the measures covered by a TFA (e.g. ownership structure). The advantage of using the OECD TFIs is that these detailed indicators can be matched with the TFA that World Trade Organization (WTO) members have committed to implement.

The OECD TFIs comprise 16 indicators. The indicators are built by ranking information for each variable from 0 to 2 , where 0 corresponds to the worst performance, 2 corresponds to the best performance, and 1 to performance that lies between these two (Moïsé et al., 2011). The database contains information on 152 countries for the year 2008. ${ }^{14}$ The information used for the TFIs are collected from existing databases, publicly available sources and questionnaires.

Figure 1 provides a mapping across the OECD TFIs, the relevant TFA articles (some examples to clarify the content of the provisions are included), and the type of costs addressed by these provisions. Some measures are important to reduce the costs of gathering information (Art. I), other measures aim at reducing the time at the border and the complexity of procedures (Art. VII and X), reducing uncertainty of treatment at the border (Art. III to VI), or reducing inefficiencies in laws and their applications by increasing transparency and predictability (Art. II and Art. VIII). We do not consider provisions related to consularization and governance because they are not included in the WTO TFA. We also exclude impartiality and transit from our analysis, because they refer respectively only to food and beverages and transit countries. Figure 2 shows the average TFI value by income level of countries for each

\footnotetext{
${ }^{13}$ Feenstra and Ma (2014) show that bilateral port efficiency has a significant and positive impact on the bilateral extensive margin of export between the trade partners, measured at country level.

${ }^{14}$ For some countries the information on which the TFI was computed refers to 2009.
} 
of the TFls we use in our empirical exercise, and shows that patterns differ across trade facilitation measures.

Our analysis looks at how gains from improved trade facilitation are distributed between small and large firms across these different types of policy measures. Indeed, some provisions such as the ability to gather information, are more likely to affect the fixed costs of trade. So we expect these provisions to be particularly beneficial to small firms. The reduction in trade costs gives firms the opportunity to enter new markets or introduce a new good in existing markets. These new firms may be smaller and less productive than current incumbents, and additional products are more likely to be introduced by small firms.

Other measures may affect mainly variable costs and certainty of delivery. Whether lower variable costs or certainty of delivery and trade conditions affects small or large firms more is an empirical question. On the one hand, uncertainty may affect large firms more because they risk more; on the other hand, large firms are better equipped to handle uncertainty.

A firm-level survey conducted by ITC (Monitoring Survey 2015) shows also that large and small firms have different priorities in relation to improvements in border procedures. While small firms put the highest value on the availability of information (Art I), large firms consider transparency of control and inspections (Art $V$ ) and the efficient release and clearance of goods (Art VII) to be more important than information availability. The discussion above points to the importance of examining the differential impact of trade facilitation measures on small and large firms on a measure-by-measure basis which we do in our paper.

Finally, note that, we use our own calculated TFI of Formalities Documents rather than the one built by the OECD. The TFI on formalities and documents as coded by the OECD provides the number of documents a country needs to export and to import. Here we are rather interested in the export cost, so the variable we focus on is the time to export into each destination country. For this reason we use the World Bank Doing Business dataset to build a direct measure of trade costs due to documents and formalities. In particular we use two variables: (i) the number of documents needed to be allowed to export into a country $j$ 
and (ii) time to export into a given market (as the number of days needed to be allowed to export into a given country $j$ ). We then compute the index following the procedure used by the OECD in their TFIs database. We assign scores 0,1 and 2 if the number of documents needed to export into a country is respectively above the $30^{\text {th }}$ percentile, below the $30^{\text {th }}$ but above the $70^{t h}$, below the $70^{t h}$. We apply the same methodology to the time to export into a country (as the number of days). We then compute the simple average between the two indexes. The higher the index, the lower is the average number of days and documents needed to export into a given destination market.

\section{French custom data and stylized facts}

Individual export data on French firms are provided yearly by the French Customs. ${ }^{15}$ However, since TFls are available only for one year, we have to work with a cross section. We use firm trade customs data in 2010. ${ }^{16}$ The TFls are built for year 2008 (or 2009 - see Moïsé et al. (2011)), so we use trade data for 2010 to reduce any concerns over reverse causality (see section 4.1 for a detailed discussion of reverse causality). The French firm dataset includes export records at the firm, product and market levels for all French exporters (or more precisely, all exporters located in France). ${ }^{17}$ Since the TFls are country specific and do not vary across sectors, we aggregate firm trade data at the firm-country level.

Firm level data are necessary to explore the heterogeneous effect of TFls by firm size. In this paper we benefit from the high-quality of French firm level data, and examine several measures of trade facilitation - those currently under negotiation at the WTO and measured by the TFls built by the OECD. The TFIs used here are also country specific, so our estimations exploit the cross country variations in firms' exports.

Moreover, firm-level export data allow us to study whether TFIs affect the intensive/extensive margins of trade and product diversification among French firms' exports. Also, we can

\footnotetext{
${ }^{15}$ These data are subject to statistical secrecy and have been accessed at CEPII.

${ }^{16}$ TFIs data are based on the "stock" of information on Trade Facilitation areas in 2008, thus they might refer to policy implementations in an unknown year preceding 2008. For this reason, we cannot adopt a panel approach using the time dimension of customs export data.

${ }^{17}$ We consider legal units, as defined by their administrative identifier.
} 
distinguish whether the effect of TFls depends on firm characteristics: small, low-productive firms may react differently to TFls than large and highly productive firms. Since we do not have information on turnover, employment, or capital for the universe of French exporters, we rely on export-based measures of firm characteristics. ${ }^{18}$ Namely, we use the total value of exports (across firm's destinations) as a proxy for firm size.

All other data come from standard sources and refer to 2010 (although they are timevarying). Per capita GDP is from World Bank (WDI). Most Favoured nation (MFN) tariff data are from the MacMap dataset. ${ }^{19}$ Distance, contiguity and common language dummies are from the CEPII gravity dataset (Head et al. (2010)). ${ }^{20}$

Before presenting the estimations, we provide a graphical depiction of the relationship between the trade margins of French firms and the simple average across TFIs, by destination country. Figure 3 shows the density functions of the export value of French firms exporting into countries with respectively high (above 1 ) and low (below 1) average TFI. The average TFI has been computed as simple average across all the TFls (within a country). Figure 3 shows that on average, French firms export more towards countries with high average TFI than towards countries with low average TFI. In figure 4 we report the average number of exported products per firm (vertical axis) as a function of the average TFI in each destination country (horizontal axis). ${ }^{21}$ Figure 5 replicates the exercise but for the intensive margin of French firms. Both scatter plots show strong positive correlations, confirming the intuition that high average TFI favors both the extensive and the intensive margins of exports. ${ }^{22}$

Table 2 classifies French firms into three size classes: small, medium and big. ${ }^{23}$. Then,

\footnotetext{
${ }^{18}$ Data on French firm characteristics are available only for firms with more than 25 employees. More than half of French exporting firms have fewer than 20 employees. To account accurately for the extensive margin of exports, we do not use data on French firm characteristics.

${ }^{19}$ We thank Houssein Guimbard for providing MFN MacMap tariff data at the country-product level in 2010.

${ }^{20}$ The descriptive statistics of all the variables in the sample are reported in table 1

${ }^{21}$ Antigua and Barbuda (ATG), Belize (BLZ), Barbados (BRB), Bahamas (BHS) and Papua New Guinea (PNG) might appear outliers. So we replicated all our estimations by dropping these countries and the results did not change. Results are available upon request.

${ }^{22}$ It could be argued that French exporters tend to serve rich countries regardless of TFls. If rich countries have high TFls, our scatter show spurious positive correlation. In figure A1 and A2 we replicate the scatter plots excluding OECD countries, and the positive relation holds. As a further robustness check on this point, figures A3 and A4 replicate the evidence by conditioning average TFIs on per capita GDP by country.

${ }^{23}$ Small firms are firms with a total export below the 25 th percentile of the distribution, while big firms are
} 
for each class of firms, we report the average number of exported products by level of TFI in the destination country for each of the policy areas of TFls studied in the paper. For example, the first entry in table 2 suggests that small firms export 1.77 products on average to destination countries with an information availability index below 0.5 . The same type of firm (small), exports on average 2.11 products to countries with an information availability index above 1.5 (last entry in the first row). By comparing the product extensive margin for different firm size classes across TFI levels, we see that big firms export a larger number of products than small firms. Moreover, for every firm size class, high TFI values correspond to larger number of exported products. Table 2 shows the heterogeneity in the extensive margins of French firms across firm size classes and TFI levels. We test this econometrically in the next section.

\section{Empirical strategy}

In this section we estimate the effect of each Trade Facilitation Indicator (see figure 1 for a description) on the export margins of French firms and test whether this effect differs by firm size. As discussed, TFls reflect different policy areas (ranging from rules to foster information flows, to simplification of procedures, to rights of appeal), these measures affect different dimensions of trade costs. So they are likely to each have a different impact on trade. We start by analyzing the effect of TFls on the firm's total exports into a destination market (firm intensive margin). We then focus on the product extensive and intensive margins of exports (i.e. respectively on the number of exported products per firm and on firm export per product). Finally, we test the effect of each TFI on French firms' export diversification.

\subsection{Firms' trade margins estimations}

We study the asymmetric effect of TFIs on heterogeneous French exporters by interacting each $\log \left(T F l_{j}\right)$ indicator with three firm size bins (indexed by $k$ ) - binned model - 
constructed from percentiles of firms' size distribution:

$$
y_{i, j}=\phi_{i}+\sum_{k}\left(\beta_{k} \log \left(T F I_{j}\right) * \operatorname{SizeBin}_{i k}\right)+\beta_{2} X_{j}+\varepsilon_{i, j}
$$

Subscripts $i$ and $j$ denote firm and destination country respectively, and $\log \left(T F I_{j}\right)$ reflects the degree of trade facilitation granted by a given destination country $j$ for each of the eight trade facilitation policy areas under the mandate of the WTO and covered by OECD data (as described above). Equation (1) is estimated for each of the eight TFls described in section 3. The results are presented in tables 3 to 5 .

Our dependent variable $y_{i, j}$ is in turn: (i) total export value by firm $i$ in market $j$ - firm intensive margin; (ii) number of products (HS-6 digit) exported by the firm into a given destination product extensive margin (iii) average export value per product - product intensive margin (computed as the total exported value by the firm over the number of products exported). We estimate equation (1) via ordinary least squares (OLS) and take the dependent variables in log. As a robustness check, we also use a Poisson estimator to account for the count nature of the extensive margin (i.e. number of exported products). In the Poisson estimations the dependent variable is taken in levels. Since TFI values are country specific, in all estimations we cluster standard errors by destination country. All firm-country specific trade variables are for 2010 (see Section 3 for more details).

We construct size bins for firms belonging to each percentile category based on quartiles. So, firms below the 25 th percentile of the (size) distribution have been classified as Small. Firms above the 75th percentile of the size distribution are classified as Big. The remaining firms are classified as Medium sized. We use the firm's total export value in 2010 (across all destinations) as a proxy for the firm size because the French Customs dataset does not provide other firm specific measures. The total amount of export is a plausible proxy for firm size and productivity (Melitz and Redding, 2014). However, using total exports of firms in 2010 to create size bins could raise endogeneity concerns. In fact, when we estimate the effect of TFls on total firm exports into a market $j$, the dependent variable is part of the 
total exports used to define our bins. To address this concern, as a robustness check, we ran equation (1) using firm size bins from total firm exports in 2005. This reduces concerns over the endogeneity of size bins. The results were unchanged. ${ }^{24}$ Moreover, it could be that firms which are small based on their employment numbers, are classed as large in terms of total exports simply because they export products with a high unit value (i.e. luxury goods). To address this concern, we ran a robustness check using firm size bins based on HS-2 specific export distribution (tables 10 and 11 show the results of these estimations). ${ }^{25}$

To allow comparison with the literature, we also estimate a simple model that assesses the average effect of TFls on firms' export margins. This specification includes the trade facilitation indicator as the main explanatory variable:

$$
y_{i, j}=\phi_{i}+\beta_{1} \log \left(T F I_{j}\right)+\beta_{2} X_{j}+\varepsilon_{i, j}
$$

Equation (2) does not differentiate firms by size, so the coefficients associated to each TFI can be compared with those estimated by the literature on the effects of TFIs on aggregate trade flow (Moïsé et al. (2011); Beverelli et al. (2015)).

Also, we study the heterogeneous effect of TFls by including in equation (2) an interaction term between the $\log \left(T F I_{j}\right)$ and a dummy variable $\left(S m a l / F i r m_{i}\right)$ which is equal to 1 if the firm is in the first quartile of the firm size distribution:

$$
y_{i, j}=\phi_{i}+\beta_{1} \log \left(T F I_{j}\right)+\beta_{2} \log \left(T F I_{j}\right) * \text { SmallFirm }_{i}+\beta_{3} X_{j}+\varepsilon_{i, j}
$$

Since model (1) is a generalization of equations (2) and (3), estimations of models (2) and (3) are intended here as robustness checks and thus reported in the appendix (see tables A1 $-\mathrm{A} 8)$.

Firm fixed effects $\left(\phi_{i}\right)$ reduce concern over potential omitted variable bias since they control

\footnotetext{
${ }^{24}$ See tables 8 and 9.

${ }^{25}$ We also built firm size bins based on firm's total exports minus destination specific exports. Results, available upon request, were unchanged.
} 
for the unobserved firm characteristics and for the characteristics of the main sector in which the firm operates. Firm fixed effects capture both the firm's size and bin sizes. Since TFls are country specific, we could not include country fixed effects. ${ }^{26}$ We include a set of country specific control variables with the aim of isolating the effect of trade facilitation measures from other country specific factors affecting the export performance of French firms (trade costs, export demand, price index and income level). The set of control variables $X_{j}$ consists of: (i) standard gravity variables (distance and common border), (ii) per capita GDP (in log) controlling for the destination country's income level, (iii) the price level in each country $j$ as a proxy for the strength of the competition (approximated by the import Trade Unit Value of country $j$ in the HS-2 sector to which firm $i$ belongs) ${ }^{27}$ (iv) the import share of country $j$ in the HS-2 sector to which the firm $i$ belongs (proxying for country $j$ 's sector specific demand). ${ }^{28}$ Finally we control also for the firm-level average ad valorem tariff faced by the firm in each destination country $j$ computed as $\tau_{i, j}=\sum_{p} \omega_{i, p} \tau_{j, p}$, where $\omega_{i, p}=\frac{x_{i, p}}{\sum_{p} x_{i, p}}$ and $x_{i, p}$ is the export value of firm for a HS-6 product code. ${ }^{29}$

The above set of control variables combined with firm fixed affects, reduce concern over omitted variables problems. Endogeneity bias can stem also from reverse causality; however, in our setting the problem of reverse causality problem is definitely less severe than the omitted variable problem since the export behavior of individual (French) firms does not have a significant impact on the trade facilitation measures imposed by a given destination country (note that each TFI applies to all exporters from all over the world and not specifically to French exporters). ${ }^{30}$ To further reduce any reverse causality concerns, since OECD trade

\footnotetext{
${ }^{26}$ Country fixed effects can be included only in specification 3. So, we report estimation results of equation (3) with firm and country fixed effects in tables A11 - A13. The sign of the coefficients of the interaction between firm size and TFls are in line with our main results - the interaction coefficients give the differential impact of trade facilitation with respect to the excluded categories (medium and big size firms). Moreover, the coefficient on tariff is always negative and highly significant (as expected). These estimations are intended as simple robustness checks; the main TFI coefficient cannot be estimated due to the presence of country fixed effects.

${ }^{27}$ For firms exporting into different HS-2 chapters (a minority, considering the breadth of HS-2 chapters), we assign a unique HS-2 representing the one in which the firm exports most.

${ }^{28} \mathrm{~A}$ more appropriate proxy for demand would be the destination country $j$ 's level of GDP. However, we cannot include GDP as a control variable because of multicollinearity with TFI. Figure 6 shows the strong positive correlation between average TFI and GDP in destination countries.

${ }^{29}$ The product structure of firm-level exports $\omega_{i, p}$, as computed here, does not vary with the destination country. This reduces concerns over the endogeneity of the firm-specific tariff measure.

${ }^{30}$ It could be argued that big firms have sufficient lobbying power to induce destination counties to improve
} 
facilitation indicators refer to 2008, we use 2010 firm level export data.

However, there is still a slight problem of potential selection bias. The TFls levels in destination countries might not constitute the (ideal) randomized treatment, and some countries may set trade facilitation to ease/impede French exporters specifically. This would lead to a selection bias in our estimations. We rely on Propensity Score Matching (PSM) to address this potential bias (Dehejia and Wahba, 2002). ${ }^{31}$ The idea is to identify a sub-sample of destination countries with different observed TFI values but similar probability to set high (above the mean) TFI values conditioned on trade costs with respect to France. Thus, the observed TFls by country in the sub-sample is randomized with respect to the trade costs for French firms. Two countries may have a similar estimated probability of high TFIs based on the trade cost from France but different observed TFls values. For example, based on our data, Argentina and Colombia have a similar estimated probability of a high trade facilitation indicator on advance rulings (since they are at a similar distance from France and impose a similar tariff level on all French exporters), but they have very different observed values on advance rulings: Colombia has a very high trade facilitation indicator (above the mean) for advance rulings, while Argentina has a below the mean trade facilitation indicator on advance ruling.

The sub-sample of destination markets identified using PSM will have different observed TFIs values but similar probability of a high trade facilitation (conditioned on the trade costs for French firms). This reduces the selection bias in our estimations. First, for each of the eight TFls described above, we estimate the propensity score as the predicted probability of a trade facilitation indicator above the mean. The econometric specification used to calculate the propensity score (linear probability model) includes a dummy for the dependent variable that is equal to 1 if the destination country $j$ has a trade facilitation indicator higher than the mean value across all destinations, and the log of distance (from France), the log of the country's per capita GDP, and the tariff level imposed on imports from France as explanatory variables.

their trade facilitation. If this were so, we would observe a strong positive relation between TFIs and the export margins of big firms. In the next section we show that this does not apply to our results.

${ }^{31}$ See Dehejia and Wahba (2002), Sianesi (2004) and Smith and Todd (2005) 
We match destination countries with TFls above the mean (treated group) with those with TFls below the mean (control group) based on the propensity score (we use one-to-one nearest neighbor matching algorithm). Finally we run equation (1) on the sub-sample of matched destination countries. This sub-sample includes only destination countries with a similar probability of a high trade facilitation indicator (but different observed TFI values). Thus, the trade facilitation indicator can be considered to be set randomly (with respect to the trade cost for French firms), and not to suffer from selection bias. We believe that the form of the selection bias described above is a remote concern, for this reason we consider PSM to be a simple robustness check (see tables 6 and 7 ).

\subsection{Export diversification estimation}

We test also whether trade facilitation measures affect the product diversification of exporting firms. The existing literature tends to focus on the effect of trade facilitation measures on countries' export diversification, arguing about the policy relevance of export diversification for the short-run volatility of national income (Cadot et al. (2011); Dennis and Shepherd (2011)). However, export product portfolio diversification is relevant also at the firm level. The dependence for export revenue on a handful of products can create excessive volatility in firm's earnings. The extensive and intensive margins of trade do not provide information about whether TFls affect the firm's exports of different products homogeneously . Here, we follow the existing literature and use the Herfindahl index as a proxy for the firm's export product diversification. The Herfindahl index $\left(H_{i, j}\right)$ is computed as follows:

$$
H_{i, j}=\sum_{k=1}^{K} s_{k j}^{2}
$$

where $s_{k}^{2}$ is the squared share of product $k$ exports in the firm's total exports (to a given destination $j$ ). This measure is firm-destination specific, and goes from zero to 1 , and captures the degree of product concentration among the firm's exports to a given destination. Values of $H_{i j}$ close to 1 indicate a highly concentrated portfolio of varieties $\left(H_{i j}\right.$ equal to 1 occurs only if the firm exports one product to a given destination market). Conversely, if 
the $H_{i j}$ index is close to zero, the firm has a homogeneously distributed portfolio of product varieties (high diversification). The results of these estimations are provided in table $12 .{ }^{32}$.

\section{The Effects of TFls}

In this section we discuss the results obtained by estimating equation (1) for the different firm trade margins and trade facilitation measures. The results of robustness checks for equations (2) and (3) are reported in the appendix. For clarity of presentation, we do not include the control variable coefficients in the main results tables. However, the reader can find the complete set of results with control variables coefficients in appendix tables A1-A8. We start by discussing the results for total export (firm intensive margin) followed by the results for the product extensive and intensive margins and our export diversification estimation.

\subsection{Firm intensive margin}

Results in table 3 show the effect of various trade facilitation measures on the firms' total exports (intensive margin) to each destination. Information availability boost trade for small and medium sized enterprises but has not significant impact on trade of large firms' trade: a $10 \%$ increase in the Information Availability index implies a respective $7 \%$ and $4 \%$ increase in export value for small and medium firms. Similarly, we find a significant positive effect of Advance rulings and Appeal procedure on small firms trade. We find no significant effect of Fees and Charges and Formalities Procedures on the export performance of French firms. ${ }^{33}$ Although Formalities Documents, and Border Agency Cooperation boost trade mainly for large firms. Qualitatively we can draw the same conclusions from estimation of the interaction term model (3)- see results reported in column 2 in tables A1-A8. Most surprisingly the coefficients of Formalities Documents, and Automation indicators are negative for small firms. ${ }^{34}$ This puzzling effect is examined further in section 5.5 where we discuss how small

\footnotetext{
${ }^{32}$ In tables A9 and A10 with the complete set of estimated coefficients

${ }^{33}$ One possible reason for the null effect of Fees and Charges and Formalities Procedures indexes is the quality of the data. As highlighted by Moïsé and Sorescu (2013) Fees and Charges data are of poor quality. Also, trade facilitation on Formality procedure is badly defined since it gives score 1 to single windows planned but planning a single windows does not have any trade effect per se.

${ }^{34}$ As explained in section 2, we compute Formality Documents index using World Bank Doing Business Indicators. So, given the puzzling negative effect of Formality Documents on small firms, we decided to split the
} 
firms may suffer from simplified and automated processing of traded goods.

To get a sense of the magnitude of these results, for each indicator of trade facilitation and each firm size we compute the predicted export value if each destination country adopts the region's best practice. For example, if all East Asia and Pacific countries adopt regional best practice in information availability, then small firms on average, would export $48.1 \%$ more and medium sized firms would export $25 \%$ more (there would be no effect on big firms). Similarly, if the East Asia and Pacific countries were to adopt the region's best practice in Advance Rulings, then small French firms would export 53.8\% more. Similarly, if Latin American countries adopted the region's best practice in Advance Rulings, then small French firms' exports to Latin America would increase by 39.7\%. From this exercise, we conclude that TFA is economically meaningful. Using these simulations we can draw the Lorenz and Kernel distribution of firm exports before and after implementation of trade facilitation best practice. Figure 9 depicts these curves for each Trade Facilitation Index. We observe that implementation of regional best practice in Information Availability, Advance Rulings and Appeal Procedure moves the distribution of firm exports to the right, and shows a more equal distribution of firms' export values (red line Lorenz curve closer to the diagonal). In contrast, implementation of best practice in Formalities Documents and Border Agency Cooperation which mostly favor big firms, makes the distribution of firm exports more unequal. ${ }^{35}$

Why is it that some measures (Formalities and documents, and Border Agency cooperation) boost trade mainly for large firms? Economic theory would suggest that trade facilitation reforms should boost trade especially for small firms. Our results suggest that this applies only to some measures. One explanation for this might stem from the way customs brokers and shipping companies operate. Firms usually outsource their customs procedures. Saving time at the border allows big exporters to arrange more efficient transportation, reduce

index into its two components: (i) number of days needed to export into country $j$ (results in table A14), and (ii) number of documents needed to export into country $j$ (results in table A15). The results in table A15 suggest that a reduction in the number of documents needed to export is beneficial for the intensive margin of big firms only. The results in table A14 show that a reduction in the number of days needed to export into a given country benefits big firms but harms small players.

${ }^{35}$ This calculations assume perfect mutual independence across destinations and do not consider the potential substitution among destinations. However, these calculations have simple illustrative purpose. 
transportation time, and save on inventory costs. Small firms benefit less because, although the time taken to complete customs procedures may be shorter, they have to wait for the ship to achieve its full container load before it sails. Therefore, they benefit only slightly if at all from the shorter time at the border.

\subsection{Product extensive margin estimations}

The product extensive margin estimation results in table 4 confirm what was described above that Information Availability, Advance Rulings and Appeal Procedure favor small firms in particular. A 10\% increase in the Information Availability index implies a $2.3 \%$ increase in the number of exported products for small firms and a $1.7 \%$ increase for medium size players. In contrast, Formalities Documents and Procedures seems to have a positive effect on trade, through the positive effect on larger firms only. These results are confirmed by Poisson estimations, used here to account for the count nature of the dependent variable. The results are reported in columns 7-9 of tables A1-A8.

As mentioned in Section 4.1, trade facilitation measures can be non-randomly adopted by countries. So, in table 6 we show the results for the extensive margin using the PSM approach to reduce any endogeneity concern. Table 6 confirms our results. In further robustness checks reported in tables 8 and 10, we use size bins based respectively on 2005 firm size distribution and on HS-2 specific size distribution. Again our results are robust.

\subsection{Product intensive margin estimations}

The results in table 5 show the effect of various TFls on the product intensive margin of firms as average exported value per product. Again, Information Availability, Advance Rulings, and Appeal Procedure TFls favor small firms only: a 10\% improvement in the Information Availability index implies a $5.4 \%$ increase in the average export value per product by small players, while a 10\% increase in Advance Rulings and Appeal Procedure measures stimulates the intensive margins of small firms by $5.1 \%$ and $1.7 \%$ respectively. As for total export estimations, small players are negatively affected by improvements in Formalities Documents 
and Automation. In section 5.5 we discuss how small firms can be disadvantaged by trade facilitation measures.

In table 7 we show the results intensive margin using the PSM approach to reduce endogeneity concerns. The results are in line with those in table 5. Finally, in tables 9 and 11 we show the results for the intensive margin using bins from the 2005 firm size distribution and HS-2 specific size distribution respectively. The results are qualitatively identical.

\subsection{Export diversification estimations}

Table 12 presents the results for export diversification based on model (1). We report robustness checks using model (2) and (3) for the export diversification measure in tables A9-A10.

Trade facilitation on Information Availability and Advance Rulings, by reducing the Herfindhal index, increases the product diversification of small and medium sized firms. Combined with the results for the extensive margins, we can conclude that Information Availability and Advance Rulings induce French firms to export a broader and more equally distributed set of products. This effect is bigger for small than for big players. Conversely, Formalities Documents and Automation improve the export diversification of medium and big firms only. This is coherent with results for the extensive margin reported in table 4 , where Formalities Documents and Formalities Automation positively affect the number of exported products for big firms only.

\subsection{Why do small exporting firms suffer from better Formalities Documents and Automation?}

In sections 5.1 and 5.3 we highlighted the puzzling negative impact of Formalities Documents and Automation for small firms. Why do small firms export less if customer documents are simplified and automated? To understand the subtle mechanisms at play, corruption - a facet of administrative hurdles at the border - needs to be considered in our reasoning related to firms' decisions. According to the rationale below, it might be that the positive effect that 
these trade facilitation measures have on trade-related corruption may disadvantage small firms.

The number of documents required, and cumbersome and inefficient procedures at the border, create opportunities for the inappropriate exercise of official discretion and collusion between customs officials and traders. ${ }^{36}$ These opportunities are enhanced by greater face-to-face interaction. Under such circumstances, large firms prefer not to risk being exposed to official discretion, or to the risk of reputation damages. Thus, big firms avoid destinations countries with a high corruption index. Figure 7 shows that big firms' exports are strongly negatively correlated with the destination country's corruption index, ${ }^{37}$ while this negative correlation is not observed for small firms. This qualitative evidence is coherent with results in Karpaty and Tingvall (2015), who use Swedish data and find that large and offshoring firms are more sensitive to corruption than other firms.

Big firms are even less inclined to export to highly corrupt countries in the presence of NGOs that are likely to monitor them (the opportunity cost of being discovered by NGOs is higher for big than for small firms - see Harrison and Scorse (2010)). Figure 8 shows that big players are less incline to export to highly corrupt countries where NGOs are particularly active. ${ }^{38}$ To support this evidence further, table 13 shows that small firms have a higher probability (than big firms, the excluded category) of their main export destination country (i.e. destination receiving the highest export value by the firm) being highly corrupt. Similarly, small firms export more intensively towards high-corruption countries, compared to big firms.

The absence of big players in highly corrupt countries leaves more space for small players. By reducing the time required to clear goods at the customs, increasing transparency and reducing the need for face-to-face interaction, trade facilitation on Formalities Documents

\footnotetext{
${ }^{36}$ There is some evidence that long delays for clearing customs increase the opportunity for trade-related fraud. E.g., Shepherd (2010b) shows that a 10\% longer delay at the border reduces trade by $14.5 \%$ in a less corrupt country, but by $15.3 \%$ in a country with high levels of corruption.

${ }^{37}$ We use the Transparency International Corruption Perception Index by to proxy for the level of corruption in destination countries (http://www.transparency.org/cpi2010).

${ }^{38}$ We use the number of news published by NGOs over the period 2002-2010 - Covalence database - as a proxy for NGO activism. See Couttenier and Hatte (2015) for more details. Countries with high NGO activism are those with the number of published news items above the median.
} 
and Automation reduce the space for corruption, encouraging big players to enter these markets. This reinforces the competition for small firms, and explains the negative effect on small firms of trade facilitation on Formalities Documents and Automation reported in tables 3 and 5.

If our reasoning is correct, we would expect: (i) a positive effect of Formalities Documents and Automation for big firms regardless of the level of corruption in the destination country (such trade facilitation measures represent progress in market access for big firms in both high and low corrupt countries), (ii) a negative effect on small firms exporting to highlycorrupt countries (here trade facilitation reinforces competition from big players), and (iii) a positive/null effect of Formalities Documents and Automation on small firms in less corrupt countries. Therefore, we reran our regressions for the sub-sample of less corrupt countries, i.e. countries with a corruption index below the median and ASYCUDA implemented in 2010 (see table 14). ${ }^{39}$ As expected in these less corrupt countries improvements in Formalities Documents and Automation have strong positive effect on big players only (although non significant for Automation), and, more importantly no negative effect on small firms. ${ }^{40}$ Conversely, if we give more weight to exports to high corrupt countries (with an NGO presence), see table $15,{ }^{41}$ we find a strong negative effect of Formalities documents and Automation on small (and medium sized) enterprises. ${ }^{42}$

\section{Conclusion}

This paper has considered the asymmetric effect of trade facilitation measures on heterogeneous exporters. By using export data for a cross-section of French firms in 2010 and an

\footnotetext{
${ }^{39}$ Among technical improvements in managing customs to reduce the opportunity for corruption, the implementation of the ASYCUDA program plays a role: Jean and Mitaritonna (2010) show that implementation of ASYCUDA (a system that supports customs computerization in developing countries) has been effective in reducing corruption at the border. We use information on countries' implementation of the ASYCUDA program to capture corruption specifically at the border.

${ }^{40}$ In tables A16 - A18 we report estimation results for all the trade facilitation measures for the sub-sample of less corrupt countries and ASYUDA implementation. Our results hold.

${ }^{41}$ High corrupted countries are few, so running on subsample implied huge selection bias, for this reason we prefer weighted OLS estimation.

${ }^{42}$ For collinearity reasons we could not include the corruption index and NGO activity as controls in the main regressions: both the corruption index and NGO activism are correlated with GDP and thus with TFIs. See figure A5.
} 
original dataset of eight Trade Facilitation Indexes (provided by the OECD), we tested the effect of TFls on the export margins of firms.

The OECD TFI dataset allows us to explore the trade effect of several trade facilitation measures (not just those related to time and document to export examined in the previous literature), while French customs data allows us to study the channels through which aggregate exports are enhanced by trade facilitation - the extensive and intensive margins of exports. We also studied the effect of trade faciliation on firms' product differentiation.

Our results show that Information Availability, Advance Rulings and Appeal Procedures have a positive effect on the extensive and intensive margins of French exporters, especially small and medium sized exporters. This is in line with the perception of such firms that lack of information is a major obstacle to trade, and the perception that the reforms mainly reduce fixed trade costs.

Differently, simplification of documents and border cooperation appear to boost trade for large firms only. Large firms appear to capture the savings from shorter time at the border, while small firms do not: we observed a negative effect of trade facilitation on Formalities Documents and Automation on the intensive margin of small firms. To try to explain this theoretically unexpected result, we introduced information on corruption and NGO activism. Lengthy and complex procedures at the border create opportunities for official discretion and collusion between customs officials and traders. In the presence of NGOs and in highly corrupt countries, large firms do not want to have to deal with these problems, leaving space in the market for small firms. The Formalities and Documents and Automation components of trade facilitation policies, by reducing the scope for corruption, are attracting large firms to the markets concerned and reinforcing the competition faced by small firms.

Looking at the effects of trade facilitation for small exporters chimes with recent international trade models, and also includes a relevant policy dimension. According to Hoekman and Shepherd (2015), an important obstacle to finalization of the TFA was the perception that gains would accrue mainly to multinational and not to small firms. While the agreement 
has now been signed, the next challenge will be how WTO members determine their own implementation schedules. A better understanding of how improving the efficiency of border procedures affects firms of different size constitutes an important contribution to the policy debate.

\section{Bibliography}

Arkolakis, C. (2010). Market penetration costs and the new consumers margin in international trade. Journal of Political Economy, 118(6):1151 - 1199.

Baron, D. (2001). Private politics, corporate social responsibility, and integrated strategy. Journal of Economics and Management Strategy, 10:7-45.

Beverelli, C., Neumueller, S., and Teh, R. (2015). Export diversification effects of the wto trade facilitation agreement. World Development, 76:293-310.

Cadot, O., Carrère, C., and Strauss-Kahn, V. (2011). Export Diversification: What's behind the Hump? The Review of Economics and Statistics, 93(2):590-605.

Chaney, T. (2008). Distorted gravity: the intensive and extensive margins of international trade. American Economic Review, 98(4):1707-1721.

Couttenier, M. and Hatte, S. (2015). Mass Media Effects on Non-Governmental Organizations. Cahiers de Recherches Economiques du Département d'Econométrie et d'Economie politique (DEEP) 13.01, Université de Lausanne, Faculté des HEC, DEEP.

Dehejia, R. H. and Wahba, S. (2002). Propensity Score-Matching Methods For Nonexperimental Causal Studies. The Review of Economics and Statistics, 84(1):151-161.

Dennis, A. and Shepherd, B. (2011). Trade Facilitation and Export Diversification. The World Economy, 34(1):101-122.

Djankov, S., Freund, C., and Pham, C. S. (2010). Trading on Time. The Review of Economics and Statistics, 92(1):166-173.

Feenstra, R. C. and Ma, H. (2014). Trade Facilitation and the Extensive Margin of Exports. The Japanese Economic Review, 65(2):158-177. 
Fernandes, A. M., Hillberry, R. H., and Mendoza Alcantara, A. (2015). Trade effects of customs reform: evidence from albania. World Bank Policy Research Working Paper 7210.

Han, H. and Piermartini, R. (2016). Trade facilitation does benefit smes. WTO staff working paper.

Harrison, A. and Scorse, J. (2010). Multinationals and Anti-sweatshop Activism. American Economic Review, 100(1):247-73.

Head, K., Mayer, T., and Ries, J. (2010). The erosion of colonial trade linkages after independence. Journal of International Economics, 81(1):1-14.

Hillberry, R. H. and Zhang, X. (2015). Policy and performance in customs : evaluating the trade facilitation agreement. Policy Research Working Paper Series 7211, The World Bank.

Hoekman, B. and Shepherd, B. (2015). Who Profits from Trade Facilitation Initiatives? Implication for African Countries. Journal of African Trade, 2(1):51-70.

Hornok, C. and Koren, M. (2015). Administrative barriers to trade. Journal of International Economics, 96(S1):S110-S122.

Hummels, D. (2007). Calculating tariff equivalent for time in trade. Nathan Associates report for US Agency for International Development.

Hummels, D. L. and Schaur, G. (2013). Time as a Trade Barrier. American Economic Review, 103(7):2935-59.

Jean, S. and Mitaritonna, C. (2010). Determinants and Pervasiveness of the Evasion of Customs Duties. Working Papers 2010-26, CEPII research center.

Karpaty, P. and Tingvall, P. (2015). Service offshoring and corruption: Do firms escape corrupt countries? Journal of Industry, Competition and Trade, 15:363-381.

Martincus, C. V., Carballo, J., and Graziano, A. (2015). Customs. Journal of International Economics, 96(1):119-137.

Melitz, M. and Redding, S. (2014). Heterogeneous firms and trade. Handbook of Interna- 
tional Economics, 4:1-54.

Melitz, M. J. (2003). The impact of trade on intra-industry reallocations and aggregate industry productivity. Econometrica, 71(6):1695-1725.

Moïsé, E., Orliac, T., and Minor, P. (2011). Trade facilitation indicators: The impact on trade costs. OECD Trade Policy Working Papers, No. 118,.

Moïsé, E. and Sorescu, S. (2013). Trade facilitation indicators: The potential impact of trade facilitation on developing countries' trade. OECD Trade Policy Papers, No. 144,.

Sequeira, S. and Djankov, S. (2014). Corruption and firm behavior: Evidence from African ports. Journal of International Economics, 94(2):277-294.

Shepherd, B. (2010a). Speed Money: Time, Corruption and Trade. DTC working paper, 2010-1.

Shepherd, B. (2010b). Trade costs and facilitation in APEC and ASEAN: delivering the goods? Chapter 5 in "Rising Non-Tariff Protectionism and Crisis Recovery", pages 93110.

Sianesi, B. (2004). An Evaluation of the Swedish System of Active Labor Market Programs in the 1990s. The Review of Economics and Statistics, 86(1):133-155.

Smith, J. A. and Todd, P. E. (2005). Does matching overcome lalonde's critique of nonexperimental estimators? Journal of Econometrics, 125(1):305-353.

Spearot, A. C. (2013). Variable demand elasticities and tariff liberalization. Journal of International Economics, 89(1):26 - 41.

WTO (2015). Speeding up trade: benefits and challenges of implementing the WTO Trade Facilitation Agreement. WTO, Geneva. 


\section{Tables and Figures}

Table 1 - In-sample descriptive statistics

\begin{tabular}{lccccc}
\hline \hline & Observations & Mean & Std Dev & Min & Max \\
\hline N. products exported (In) & 465726 & 0.78 & 0.99 & 0.00 & 6.75 \\
Export value (In) & 465726 & 9.99 & 2.30 & 4.32 & 16.16 \\
Average Export per product (In) & 465726 & 9.21 & 2.07 & 0.63 & 16.15 \\
Product concentration (HH) & 465726 & 0.75 & 0.30 & 0.01 & 1.00 \\
Information Availability & 456885 & 0.42 & 0.21 & -1.61 & 0.69 \\
Advance Ruling & 384529 & 0.33 & 0.30 & -1.10 & 0.69 \\
Appeal Procedure & 440173 & 0.35 & 0.38 & -0.92 & 0.69 \\
Fees and Charges & 441060 & 0.38 & 0.32 & -1.10 & 0.69 \\
Formalities - Documents & 439893 & 0.38 & 0.41 & -0.69 & 0.69 \\
Formalities - Automation & 464710 & 0.31 & 0.49 & -1.39 & 0.69 \\
Formalities - Procedures & 454116 & -0.02 & 0.31 & -1.20 & 0.69 \\
Border Agency Cooperation & 372079 & 0.31 & 0.41 & -1.39 & 0.69 \\
Per Capita GDP (In) & 465726 & 9.69 & 1.32 & 5.39 & 11.36 \\
Distance (In) & 465726 & 7.67 & 1.06 & 6.16 & 9.85 \\
Contiguity & 465726 & 0.26 & 0.44 & 0.00 & 1.00 \\
Import share & 465726 & 0.04 & 0.05 & 0.00 & 0.48 \\
Ln(tariff+1) & 465726 & 0.06 & 0.09 & 0.00 & 2.40 \\
Ln(TUV) & 465754 & 4.39 & 1.78 & -0.81 & 15.65 \\
\hline
\end{tabular}




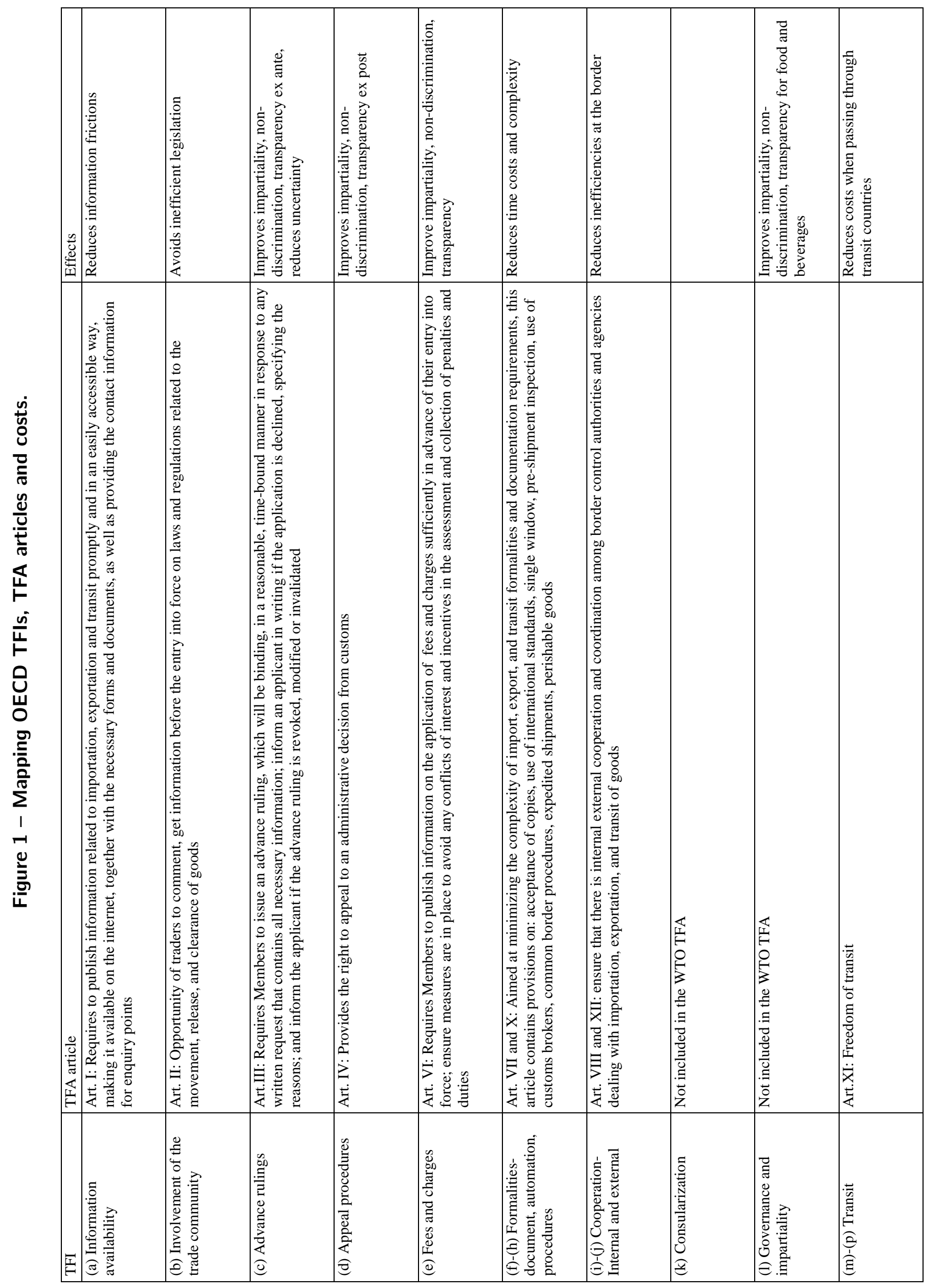


Figure 2 - TFls by income level.

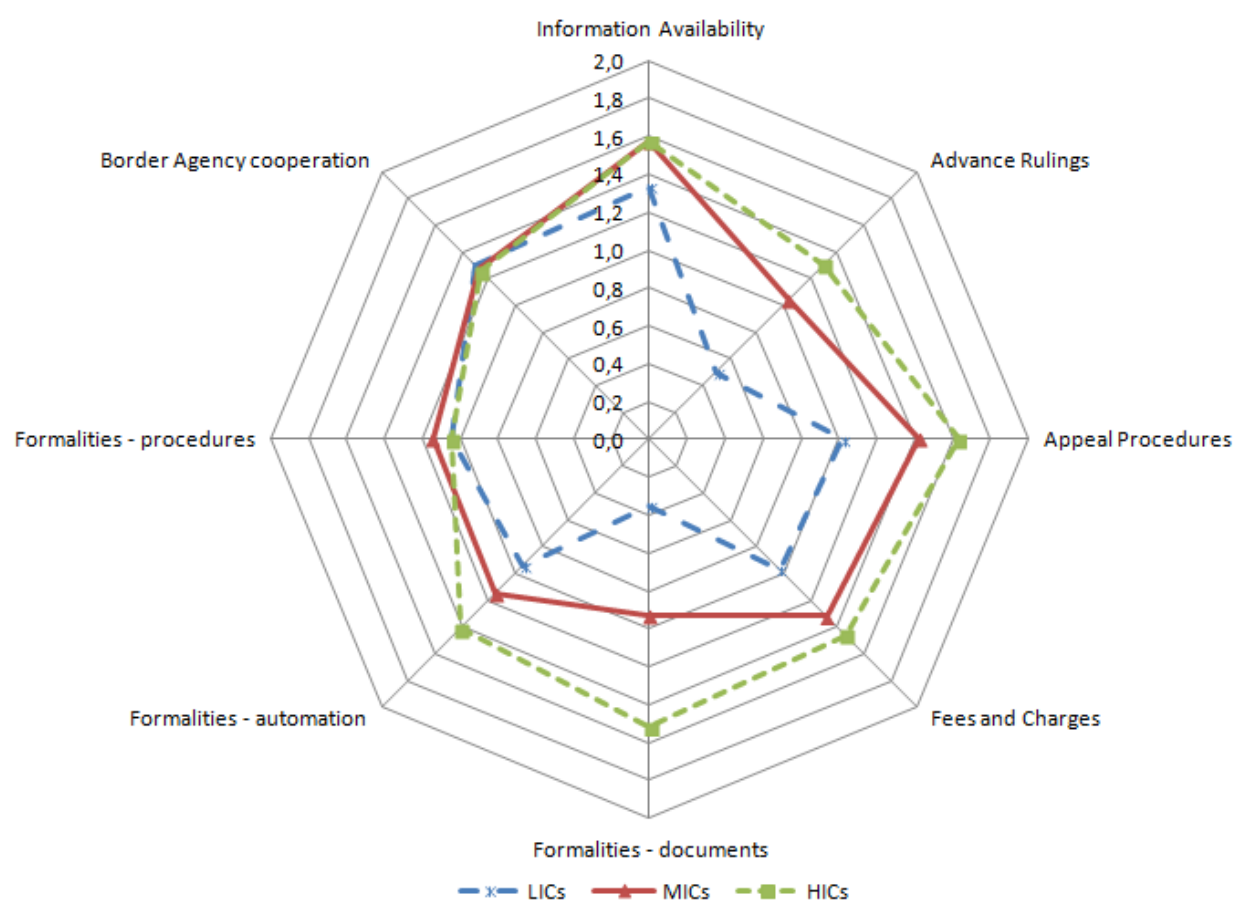

Note: Income groups classification by World Bank (LIC=Low Income Country; MIC=low and high Middle Income Country; HIC= High Income Country OECD and non-OECD). Source: Authors calculations on TFI database, OECD 
Figure 3 - Export density and TFI levels.

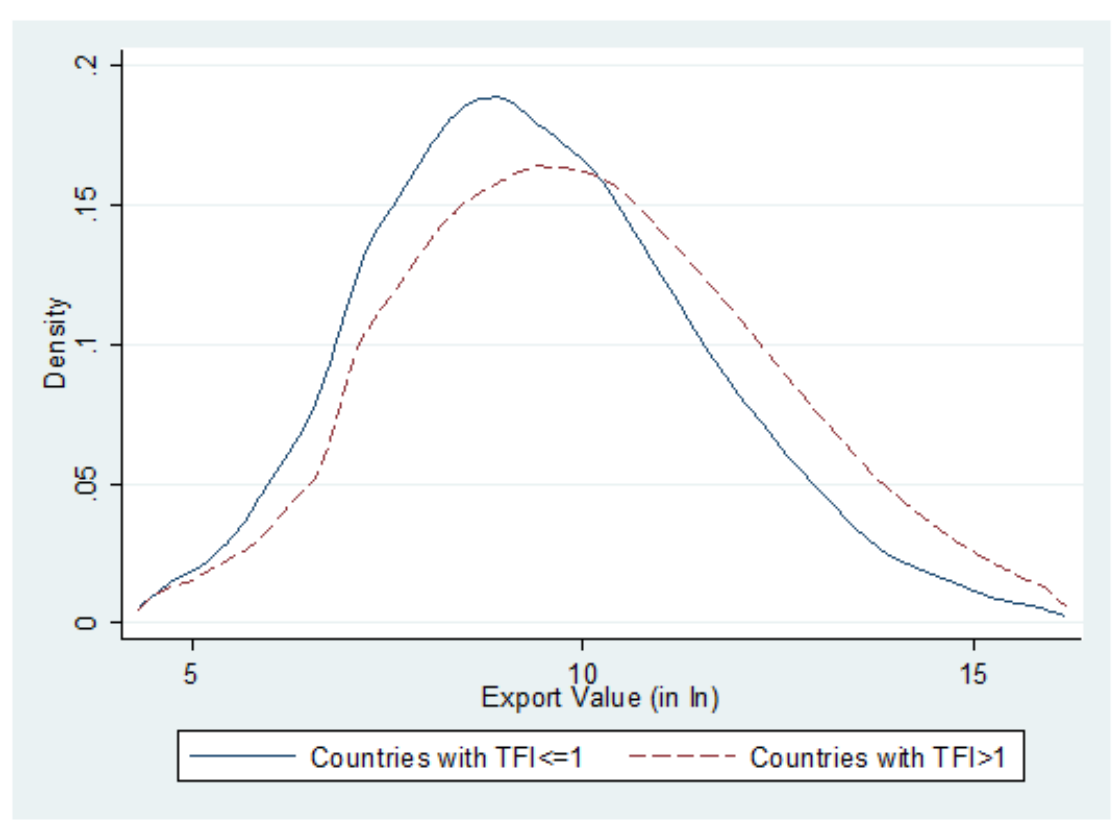

Source: Authors calculations on TFI database, OECD

Figure 4 - Number of exported products and average TFI by country.

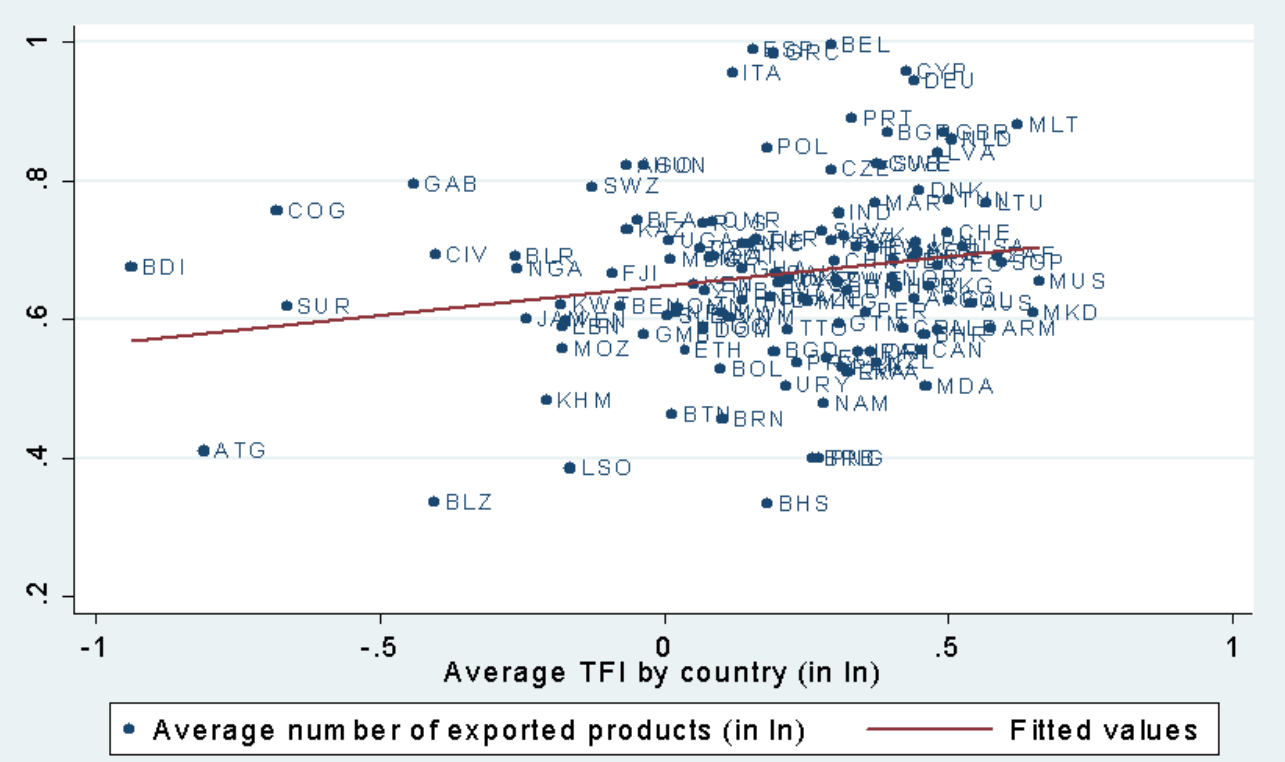

Source: Authors calculations on TFI database, OECD 
Figure 5 - Exported values and average TFI by country.

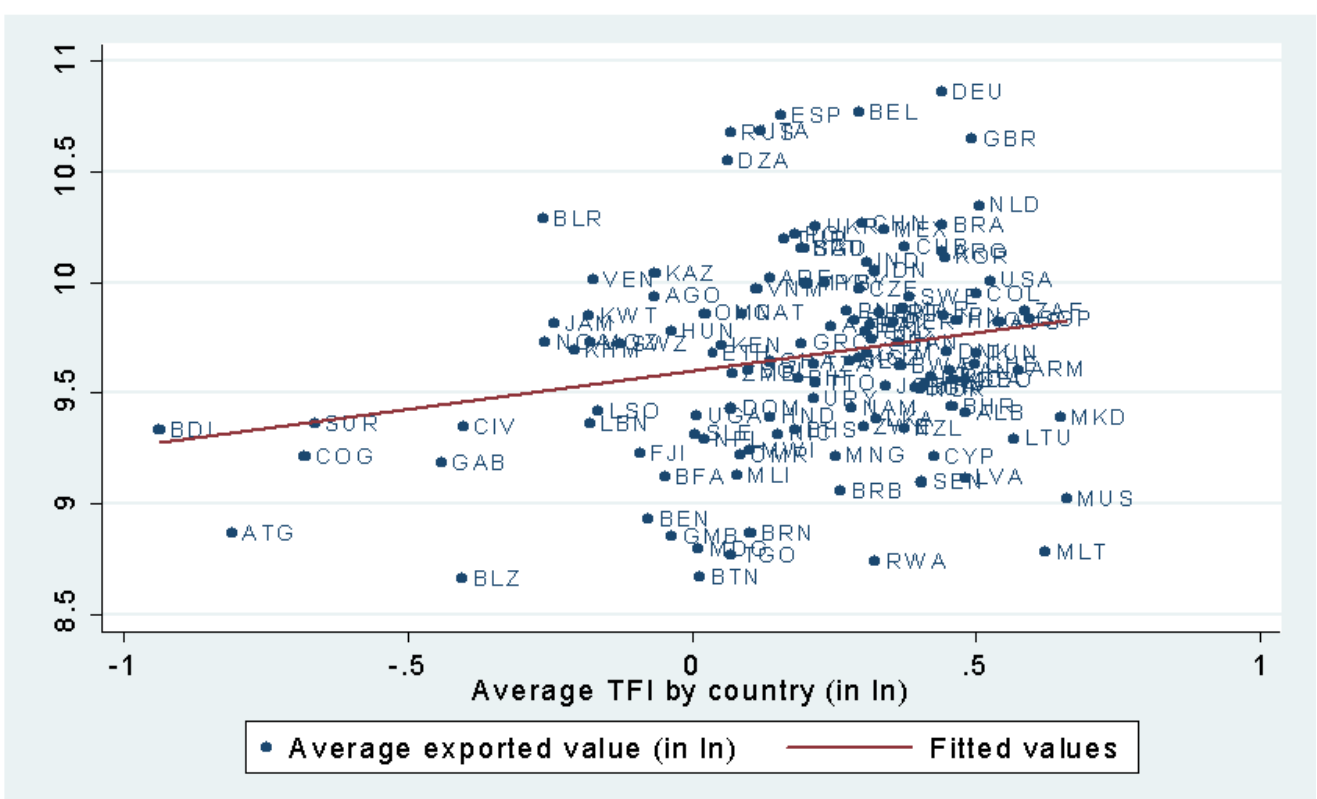

Source: Authors calculations on TFI database, OECD

Figure 6 - GDP and average TFI by country.

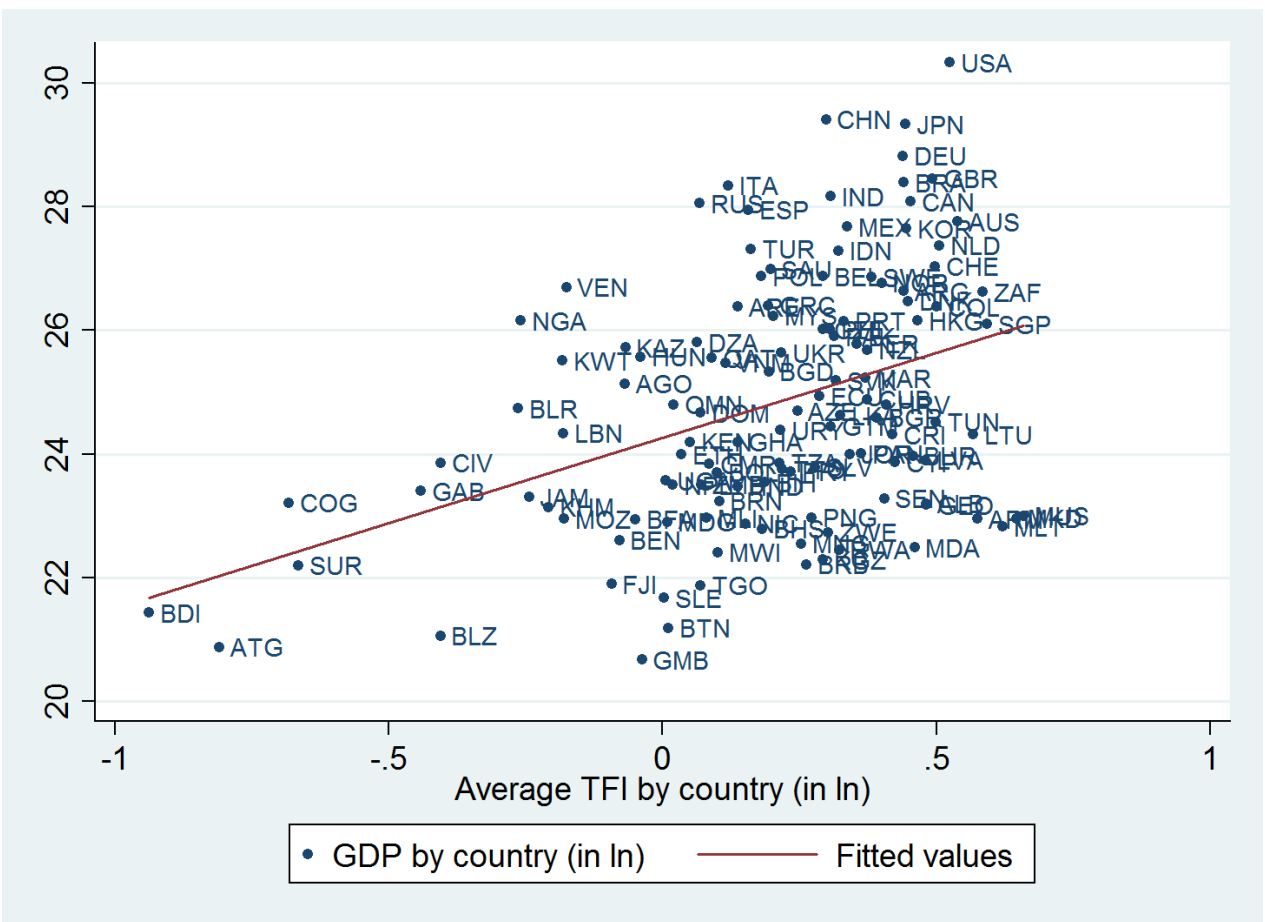

Source: Authors calculations on TFI database, OECD 
Figure 7 - Small vs Big firms exports and corruption index by destination country
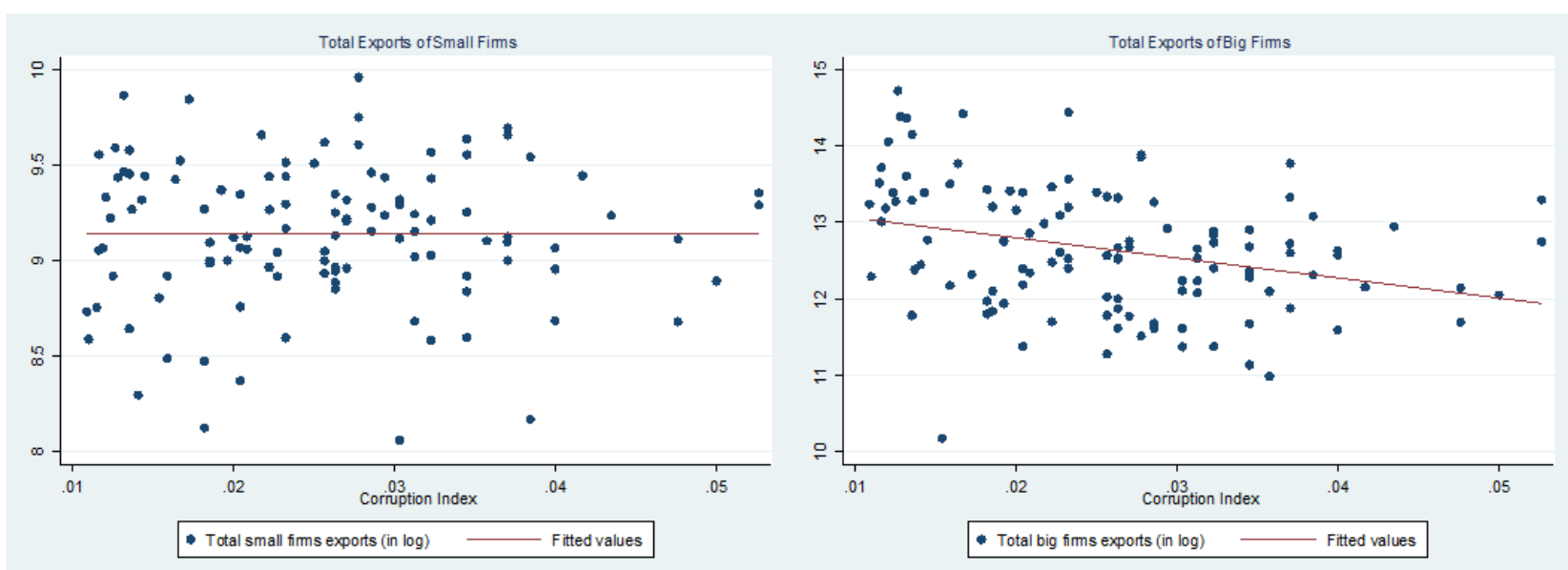

Source: Authors calculations on French Custom Data and Corruption Perception Index 2010.

Figure 8 - Exported value of big firms and corruption index. Full sample vs. high NGO activism countries.
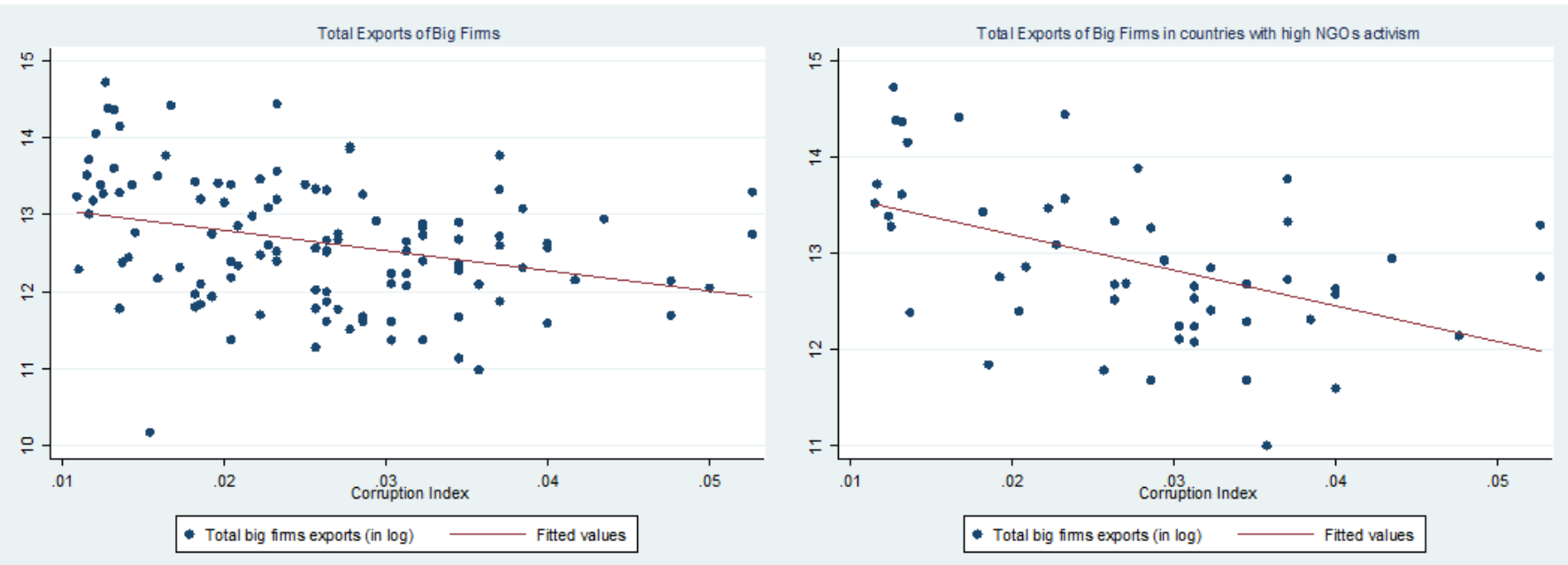

Source: Authors calculations on TFI database, OECD 
Table 2 - Average number of exported products by firm size and TFI level

\begin{tabular}{|c|c|c|c|c|c|}
\hline & Bin & TFI below 0.5 & $\begin{array}{c}\text { TFI between } \\
0.5 \text { and } 1\end{array}$ & $\begin{array}{c}\text { TFI between } \\
1 \text { and } 1.5\end{array}$ & TFI above 1.5 \\
\hline \multirow{3}{*}{ Information Availability } & 1 & 1.77 & 1.81 & 2.41 & 2.11 \\
\hline & 2 & 2.31 & 2.80 & 4.68 & 3.90 \\
\hline & 3 & 4.53 & 6.06 & 8.99 & 7.55 \\
\hline \multirow{3}{*}{ Advance Rulings } & 1 & 2.05 & 2.97 & 2.35 & 2.10 \\
\hline & 2 & 3.35 & 5.66 & 4.64 & 3.79 \\
\hline & 3 & 6.51 & 11.11 & 8.73 & 7.52 \\
\hline \multirow{3}{*}{ Appeal Procedure } & 1 & 2.15 & 2.33 & 2.18 & 2.25 \\
\hline & 2 & 2.14 & 4.67 & 4.17 & 4.17 \\
\hline & 3 & 4.69 & 9.12 & 8.00 & 7.93 \\
\hline \multirow{3}{*}{ Fees and Charges } & 1 & 1.73 & 1.98 & 2.12 & 2.28 \\
\hline & 2 & 2.60 & 3.78 & 4.02 & 4.36 \\
\hline & 3 & 5.98 & 7.56 & 7.78 & 8.32 \\
\hline \multirow{3}{*}{ Formalities and Documents } & 1 & 2.18 & 1.76 & 1.99 & 2.37 \\
\hline & 2 & 3.79 & 2.77 & 3.58 & 4.58 \\
\hline & 3 & 7.47 & 6.12 & 6.73 & 9.05 \\
\hline \multirow{3}{*}{ Formalities Automation } & 1 & 2.03 & 1.93 & 2.42 & 2.23 \\
\hline & 2 & 3.76 & 3.41 & 4.78 & 4.21 \\
\hline & 3 & 6.71 & 7.10 & 8.16 & 8.32 \\
\hline \multirow{3}{*}{ Formalities Procedures } & 1 & 1.92 & 2.33 & 2.24 & 1.95 \\
\hline & 2 & 4.15 & 4.32 & 4.34 & 2.95 \\
\hline & 3 & 8.01 & 8.36 & 8.29 & 6.22 \\
\hline \multirow{3}{*}{ Border Agency } & 1 & 2.68 & 2.34 & 1.97 & 2.15 \\
\hline & 2 & 5.41 & 4.13 & 3.67 & 3.88 \\
\hline & 3 & 10.20 & 8.69 & 7.58 & 7.32 \\
\hline
\end{tabular}

Average number of products exported by a firm of a given size bin toward a destination markets with a given TFI level.

Table 3 - Total exports estimations.

\begin{tabular}{lcccccccc}
\hline \hline & \multicolumn{7}{c}{ Dep. Variable: Total export per firm (in log) } \\
\hline & $\begin{array}{l}\text { Information } \\
\text { Availability }\end{array}$ & $\begin{array}{c}\text { Advance } \\
\text { Ruling }\end{array}$ & $\begin{array}{c}\text { Appeal } \\
\text { Procedure }\end{array}$ & $\begin{array}{c}\text { Fees and } \\
\text { Charges }\end{array}$ & $\begin{array}{c}\text { Formalities } \\
\text { Document }\end{array}$ & $\begin{array}{c}\text { Formalities } \\
\text { Automation }\end{array}$ & $\begin{array}{c}\text { Formalities } \\
\text { Procedures }\end{array}$ & $\begin{array}{c}\text { Border agency } \\
\text { (Int. + ext.) }\end{array}$ \\
\hline TFI (log)*Small Size & $0.779^{* *}$ & $0.647^{* * *}$ & $0.245^{* *}$ & -0.087 & $-0.473^{* * *}$ & $-0.202^{* *}$ & 0.102 & -0.174 \\
& $(0.301)$ & $(0.146)$ & $(0.101)$ & $(0.149)$ & $(0.138)$ & $(0.089)$ & $(0.128)$ & $(0.145)$ \\
TFI (log)*Medium Size & $0.405^{*}$ & 0.248 & -0.104 & 0.102 & 0.010 & -0.031 & -0.033 & 0.221 \\
& $(0.212)$ & $(0.186)$ & $(0.149)$ & $(0.155)$ & $(0.151)$ & $(0.140)$ & $(0.189)$ & $(0.133)$ \\
TFI (log)*Big Size & -0.005 & -0.163 & -0.239 & 0.307 & $0.455^{* *}$ & 0.294 & -0.297 & $0.357^{*}$ \\
& $(0.267)$ & $(0.317)$ & $(0.370)$ & $(0.266)$ & $(0.219)$ & $(0.187)$ & $(0.208)$ & $(0.185)$ \\
\hline Firm FE & Yes & Yes & Yes & Yes & Yes & Yes & Yes & Yes \\
Country Controls & Yes & Yes & Yes & Yes & Yes & Yes & Yes & Yes \\
\hline Observations & 456,884 & 384,529 & 440,172 & 441,059 & 439,892 & 464,709 & 454,115 & 372,078 \\
R-squared & 0.075 & 0.075 & 0.069 & 0.073 & 0.076 & 0.075 & 0.072 & 0.052 \\
Number of i & 91,082 & 82,585 & 90,817 & 90,305 & 89,616 & 92,333 & 91,214 & 85,385 \\
\hline
\end{tabular}

Standard errors are clustered within destination country.

All regressions include firm fixed effects and country controls.

$* * * p<0,01 ; * * p<0,05 ; * p<0,1$. 
Table 4 - Extensive margin estimations.

\begin{tabular}{lcccccccc}
\hline \hline & \multicolumn{7}{c}{ Dep. Variable: } & Number of exported products per firms (in log) \\
\hline & Information & Advance & Appeal & Fees and & Formalities & Formalities & Formalities & Border agency \\
& Availability & Ruling & Procedure & Charges & Document & Automation & Procedures & (Int. + ext.) \\
\hline TFI (log)*Small Size & $0.236^{* *}$ & $0.137^{* * *}$ & $0.069^{* *}$ & -0.018 & -0.061 & -0.025 & 0.020 & -0.064 \\
& $(0.091)$ & $(0.046)$ & $(0.031)$ & $(0.038)$ & $(0.045)$ & $(0.025)$ & $(0.036)$ & $(0.043)$ \\
TFI (log)*Medium Size & $0.175^{* * *}$ & 0.062 & 0.016 & 0.019 & $0.074 *$ & 0.034 & 0.006 & 0.018 \\
& $(0.065)$ & $(0.050)$ & $(0.039)$ & $(0.039)$ & $(0.041)$ & $(0.029)$ & $(0.041)$ & $(0.035)$ \\
TFI (log)*Big Size & 0.061 & 0.004 & -0.010 & 0.095 & $0.233^{* * *}$ & $0.145^{* * *}$ & -0.043 & 0.068 \\
& $(0.075)$ & $(0.096)$ & $(0.110)$ & $(0.082)$ & $(0.068)$ & $(0.048)$ & $(0.057)$ & $(0.053)$ \\
\hline Firm FE & Yes & Yes & Yes & Yes & Yes & Yes & Yes & Yes \\
Country Controls & Yes & Yes & Yes & Yes & Yes & Yes & Yes & Yes \\
\hline Observations & 456,884 & 384,529 & 440,172 & 441,059 & 439,892 & 464,709 & 454,115 & 372,078 \\
R-squared & 0.066 & 0.064 & 0.062 & 0.064 & 0.068 & 0.066 & 0.064 & 0.046 \\
Number of i & 91,082 & 82,585 & 90,817 & 90,305 & 89,616 & 92,333 & 91,214 & 85,385 \\
\hline
\end{tabular}

Standard errors are clustered within destination country.

All regressions include firm fixed effects and country controls.

$* * * p<0,01 ; * * p<0,05 ; * p<0,1$.

Table 5 - Intensive margin estimations.

\begin{tabular}{lcccccccc}
\hline \hline & \multicolumn{7}{c}{ Dep. Variable: Firm export per product (in log) } \\
\hline & $\begin{array}{c}\text { Information } \\
\text { Availability }\end{array}$ & $\begin{array}{c}\text { Advance } \\
\text { Ruling }\end{array}$ & $\begin{array}{c}\text { Appeal } \\
\text { Procedure }\end{array}$ & $\begin{array}{c}\text { Fees and } \\
\text { Charges }\end{array}$ & $\begin{array}{c}\text { Formalities } \\
\text { Document }\end{array}$ & $\begin{array}{c}\text { Formalities } \\
\text { Automation }\end{array}$ & $\begin{array}{c}\text { Formalities } \\
\text { Procedures }\end{array}$ & $\begin{array}{c}\text { Border agency } \\
\text { (Int. + ext.) }\end{array}$ \\
\hline TFI (log)*Small Size & $0.543^{* *}$ & $0.511^{* * *}$ & $0.175^{* *}$ & -0.070 & $-0.412^{* * *}$ & $-0.177^{* *}$ & 0.083 & -0.109 \\
& $(0.220)$ & $(0.108)$ & $(0.079)$ & $(0.124)$ & $(0.112)$ & $(0.076)$ & $(0.117)$ & $(0.112)$ \\
TFI (log)*Medium Size & 0.230 & 0.186 & -0.120 & 0.083 & -0.064 & -0.066 & -0.039 & $0.203^{*}$ \\
& $(0.170)$ & $(0.152)$ & $(0.124)$ & $(0.148)$ & $(0.135)$ & $(0.125)$ & $(0.184)$ & $(0.121)$ \\
TFI (log)*Big Size & -0.065 & -0.168 & -0.229 & 0.212 & 0.222 & 0.149 & -0.255 & $0.289^{*}$ \\
& $(0.209)$ & $(0.231)$ & $(0.269)$ & $(0.207)$ & $(0.166)$ & $(0.151)$ & $(0.190)$ & $(0.148)$ \\
\hline Firm FE & Yes & Yes & Yes & Yes & Yes & Yes & Yes & Yes \\
Country Controls & Yes & Yes & Yes & Yes & Yes & Yes & Yes & Yes \\
\hline Observations & 456,884 & 384,529 & 440,172 & 441,059 & 439,892 & 464,709 & 454,115 & 372,078 \\
R-squared & 0.041 & 0.043 & 0.038 & 0.040 & 0.041 & 0.041 & 0.040 & 0.030 \\
Number of i & 91,082 & 82,585 & 90,817 & 90,305 & 89,616 & 92,333 & 91,214 & 85,385 \\
\hline
\end{tabular}

Standard errors are clustered within destination country.

All regressions include firm fixed effects and country controls.

*** $p<0,01 ; * * p<0,05 ; * p<0,1$. 
Table 6 - Extensive margin estimations: robustness check using PSM.

\begin{tabular}{lcccccccc}
\hline \hline & \multicolumn{7}{c}{ Dep. Variable: } & Number of exported products per firm (in log) \\
\hline & $\begin{array}{l}\text { Information } \\
\text { Availability }\end{array}$ & $\begin{array}{c}\text { Advance } \\
\text { Ruling }\end{array}$ & $\begin{array}{c}\text { Appeal } \\
\text { Procedure }\end{array}$ & $\begin{array}{c}\text { Fees and } \\
\text { Charges }\end{array}$ & $\begin{array}{c}\text { Formalities } \\
\text { Document }\end{array}$ & $\begin{array}{c}\text { Formalities } \\
\text { Automation }\end{array}$ & $\begin{array}{c}\text { Formalities } \\
\text { Procedures }\end{array}$ & $\begin{array}{c}\text { Border agency } \\
\text { (Int. + ext.) }\end{array}$ \\
\hline TFI $(\log )^{*}$ Small Size & 0.102 & $0.143^{* * *}$ & $0.102^{* * *}$ & 0.003 & -0.053 & 0.005 & 0.011 & $-0.076^{*}$ \\
& $(0.070)$ & $(0.045)$ & $(0.037)$ & $(0.055)$ & $(0.046)$ & $(0.039)$ & $(0.033)$ & $(0.046)$ \\
TFI $(\log ) *$ Medium Size & $0.116^{*}$ & 0.059 & 0.024 & 0.004 & $0.123^{* *}$ & 0.046 & -0.016 & -0.005 \\
& $(0.070)$ & $(0.050)$ & $(0.042)$ & $(0.048)$ & $(0.050)$ & $(0.039)$ & $(0.043)$ & $(0.039)$ \\
TFI $(\log ) *$ Big Size & 0.073 & -0.031 & -0.057 & 0.097 & $0.257^{* * *}$ & $0.163^{* *}$ & -0.031 & 0.048 \\
& $(0.072)$ & $(0.100)$ & $(0.104)$ & $(0.108)$ & $(0.087)$ & $(0.067)$ & $(0.066)$ & $(0.059)$ \\
\hline Firm FE & Yes & Yes & Yes & Yes & Yes & Yes & Yes & Yes \\
Country Controls & Yes & Yes & Yes & Yes & Yes & Yes & Yes & Yes \\
\hline Observations & 338,761 & 379,413 & 398,080 & 411,456 & 337,464 & 422,778 & 301,632 & 343,749 \\
R-squared & 0.071 & 0.062 & 0.063 & 0.063 & 0.082 & 0.064 & 0.054 & 0.048 \\
Number of $i$ & 75,991 & 82,382 & 84,083 & 88,068 & 74,052 & 87,274 & 83,393 & 84,102 \\
\hline
\end{tabular}

Standard errors are clustered within destination country.

All regressions include firm fixed effects.

*** $p<0,01 ; * * p<0,05 ; * p<0,1$.

Table 7 - Intensive margin estimations: robustness check using PSM.

\begin{tabular}{lcccccccc}
\hline \hline & \multicolumn{7}{c}{ Dep. Variable: Firm export per product (in log) } \\
\hline & $\begin{array}{l}\text { Information } \\
\text { Availability }\end{array}$ & $\begin{array}{c}\text { Advance } \\
\text { Ruling }\end{array}$ & $\begin{array}{c}\text { Appeal } \\
\text { Procedure }\end{array}$ & $\begin{array}{c}\text { Fees and } \\
\text { Charges }\end{array}$ & $\begin{array}{c}\text { Formalities } \\
\text { Document }\end{array}$ & $\begin{array}{c}\text { Formalities } \\
\text { Automation }\end{array}$ & $\begin{array}{c}\text { Formalities } \\
\text { Procedures }\end{array}$ & $\begin{array}{c}\text { Border agency } \\
\text { (Int. + ext.) }\end{array}$ \\
\hline TFI (log)*Small Size & 0.230 & $0.534^{* * *}$ & $0.302^{* * *}$ & 0.106 & $-0.282^{* *}$ & -0.162 & -0.025 & -0.145 \\
& $(0.175)$ & $(0.107)$ & $(0.069)$ & $(0.156)$ & $(0.121)$ & $(0.104)$ & $(0.117)$ & $(0.112)$ \\
TFI (log)*Medium Size & 0.045 & 0.191 & -0.060 & $0.251^{*}$ & -0.031 & -0.053 & -0.176 & 0.123 \\
& $(0.167)$ & $(0.158)$ & $(0.129)$ & $(0.134)$ & $(0.191)$ & $(0.174)$ & $(0.201)$ & $(0.119)$ \\
TFI (log)*Big Size & -0.101 & -0.225 & -0.303 & $0.387^{*}$ & 0.148 & 0.126 & $-0.298^{*}$ & 0.195 \\
& $(0.195)$ & $(0.244)$ & $(0.264)$ & $(0.210)$ & $(0.227)$ & $(0.198)$ & $(0.176)$ & $(0.154)$ \\
\hline Firm FE & Yes & Yes & Yes & Yes & Yes & Yes & Yes & Yes \\
Country Controls & Yes & Yes & Yes & Yes & Yes & Yes & Yes & Yes \\
\hline Observations & 338,761 & 379,413 & 398,080 & 411,456 & 337,464 & 422,778 & 301,632 & 343,749 \\
R-squared & 0.055 & 0.044 & 0.040 & 0.043 & 0.048 & 0.038 & 0.028 & 0.028 \\
Number of i & 75,991 & 82,382 & 84,083 & 88,068 & 74,052 & 87,274 & 83,393 & 84,102 \\
\hline
\end{tabular}

Standard errors are clustered within destination country.

All regressions include firm fixed effects.

$* * * p<0,01 ; * * p<0,05 ; * p<0,1$. 
Table 8 - Extensive margin estimations: robustness check using bins from firms size distribution in 2005.

\begin{tabular}{lcccccccc}
\hline \hline & \multicolumn{7}{c}{ Dep. Variable: Number of exported products per firm (in log) } \\
\hline & $\begin{array}{l}\text { Information } \\
\text { Availability }\end{array}$ & $\begin{array}{c}\text { Advance } \\
\text { Ruling }\end{array}$ & $\begin{array}{c}\text { Appeal } \\
\text { Procedure }\end{array}$ & $\begin{array}{c}\text { Fees and } \\
\text { Charges }\end{array}$ & $\begin{array}{c}\text { Formalities } \\
\text { Document }\end{array}$ & $\begin{array}{c}\text { Formalities } \\
\text { Automation }\end{array}$ & $\begin{array}{c}\text { Formalities } \\
\text { Procedures }\end{array}$ & $\begin{array}{c}\text { Border agency } \\
\text { (Int. + ext.) }\end{array}$ \\
\hline TFI (log)*Small Size & $0.232^{* * *}$ & $0.138^{* * *}$ & $0.067^{*}$ & -0.005 & -0.027 & -0.011 & 0.047 & -0.038 \\
& $(0.084)$ & $(0.047)$ & $(0.038)$ & $(0.040)$ & $(0.043)$ & $(0.030)$ & $(0.042)$ & $(0.043)$ \\
TFI $(\log ) *$ Medium Size & $0.181^{* * *}$ & 0.060 & 0.016 & 0.021 & $0.080^{*}$ & 0.038 & 0.009 & 0.021 \\
& $(0.067)$ & $(0.052)$ & $(0.039)$ & $(0.042)$ & $(0.043)$ & $(0.032)$ & $(0.043)$ & $(0.037)$ \\
TFI $(\log ) *$ Big Size & 0.063 & 0.017 & 0.008 & 0.093 & $0.227^{* * *}$ & $0.145^{* * *}$ & -0.048 & 0.061 \\
& $(0.075)$ & $(0.097)$ & $(0.118)$ & $(0.082)$ & $(0.069)$ & $(0.048)$ & $(0.059)$ & $(0.053)$ \\
\hline Firm FE & Yes & Yes & Yes & Yes & Yes & Yes & Yes & Yes \\
Country Controls & Yes & Yes & Yes & Yes & Yes & Yes & Yes & Yes \\
\hline Observations & 361,134 & 304,987 & 347,099 & 348,037 & 347,569 & 366,897 & 358,570 & 292,402 \\
R-squared & 0.070 & 0.068 & 0.065 & 0.067 & 0.071 & 0.069 & 0.067 & 0.048 \\
Number of i & 50,317 & 47,811 & 50,087 & 50,134 & 49,879 & 50,699 & 50,375 & 47,656 \\
\hline
\end{tabular}

Standard errors are clustered within destination country.

All regressions include firm fixed effects.

$* * * p<0,01 ; * * p<0,05 ; * p<0,1$.

Table 9 - Intensive margin estimations: robustness check using bins from firms size distribution in 2005.

\begin{tabular}{lcccccccc}
\hline \hline & \multicolumn{7}{c}{ Dep. Variable: Firm export per product (in log) } \\
\hline & $\begin{array}{l}\text { Information } \\
\text { Availability }\end{array}$ & $\begin{array}{c}\text { Advance } \\
\text { Ruling }\end{array}$ & $\begin{array}{c}\text { Appeal } \\
\text { Procedure }\end{array}$ & $\begin{array}{c}\text { Fees and } \\
\text { Charges }\end{array}$ & $\begin{array}{c}\text { Formalities } \\
\text { Document }\end{array}$ & $\begin{array}{c}\text { Formalities } \\
\text { Automation }\end{array}$ & $\begin{array}{c}\text { Formalities } \\
\text { Procedures }\end{array}$ & $\begin{array}{c}\text { Border agency } \\
\text { (Int. + ext.) }\end{array}$ \\
\hline TFI (log)*Small Size & $0.489^{* *}$ & $0.401^{* * *}$ & 0.096 & -0.001 & $-0.342^{* * *}$ & $-0.169^{*}$ & 0.003 & -0.038 \\
& $(0.195)$ & $(0.122)$ & $(0.089)$ & $(0.135)$ & $(0.118)$ & $(0.099)$ & $(0.158)$ & $(0.109)$ \\
TFI (log)*Medium Size & 0.212 & 0.178 & -0.130 & 0.087 & -0.051 & -0.057 & -0.043 & $0.223^{*}$ \\
& $(0.171)$ & $(0.157)$ & $(0.131)$ & $(0.152)$ & $(0.138)$ & $(0.127)$ & $(0.188)$ & $(0.128)$ \\
TFI (log)*Big Size & -0.034 & -0.126 & -0.184 & 0.180 & 0.182 & 0.126 & -0.249 & $0.282^{* *}$ \\
& $(0.200)$ & $(0.217)$ & $(0.260)$ & $(0.202)$ & $(0.164)$ & $(0.147)$ & $(0.183)$ & $(0.139)$ \\
\hline Firm FE & Yes & Yes & Yes & Yes & Yes & Yes & Yes & Yes \\
Country Controls & Yes & Yes & Yes & Yes & Yes & Yes & Yes & Yes \\
\hline Observations & 361,134 & 304,987 & 347,099 & 348,037 & 347,569 & 366,897 & 358,570 & 292,402 \\
R-squared & 0.043 & 0.045 & 0.039 & 0.041 & 0.042 & 0.042 & 0.041 & 0.031 \\
Number of i & 50,317 & 47,811 & 50,087 & 50,134 & 49,879 & 50,699 & 50,375 & 47,656 \\
\hline
\end{tabular}

Standard errors are clustered within destination country.

All regressions include firm fixed effects.

*** $p<0,01 ; * * p<0,05 ; * p<0,1$. 
Table 10 - Extensive margin estimations: robustness check using bins from HS-2 specific size distribution.

\begin{tabular}{lcccccccc}
\hline \hline & \multicolumn{7}{c}{ Dep. Variable: Number of exported products per firm (in log) } \\
\hline & $\begin{array}{l}\text { Information } \\
\text { Availability }\end{array}$ & $\begin{array}{c}\text { Advance } \\
\text { Ruling }\end{array}$ & $\begin{array}{c}\text { Appeal } \\
\text { Procedure }\end{array}$ & $\begin{array}{c}\text { Fees and } \\
\text { Charges }\end{array}$ & $\begin{array}{c}\text { Formalities } \\
\text { Document }\end{array}$ & $\begin{array}{c}\text { Formalities } \\
\text { Automation }\end{array}$ & $\begin{array}{c}\text { Formalities } \\
\text { Procedures }\end{array}$ & $\begin{array}{c}\text { Border agency } \\
\text { (Int. + ext.) }\end{array}$ \\
\hline TFI (log)*Small Size & $0.220^{* *}$ & $0.124^{* * *}$ & $0.061^{* *}$ & -0.034 & -0.063 & -0.023 & 0.030 & -0.046 \\
& $(0.084)$ & $(0.043)$ & $(0.029)$ & $(0.035)$ & $(0.041)$ & $(0.024)$ & $(0.035)$ & $(0.039)$ \\
TFI $(\log ) *$ Medium Size & $0.177^{* * *}$ & 0.068 & 0.014 & 0.022 & $0.075^{*}$ & 0.035 & 0.010 & 0.021 \\
& $(0.063)$ & $(0.050)$ & $(0.039)$ & $(0.040)$ & $(0.041)$ & $(0.030)$ & $(0.040)$ & $(0.034)$ \\
TFI $(\log ) *$ Big Size & 0.059 & -0.005 & -0.002 & 0.099 & $0.239 * * *$ & $0.150^{* * *}$ & -0.054 & 0.062 \\
& $(0.075)$ & $(0.094)$ & $(0.108)$ & $(0.081)$ & $(0.067)$ & $(0.048)$ & $(0.058)$ & $(0.053)$ \\
\hline Firm FE & Yes & Yes & Yes & Yes & Yes & Yes & Yes & Yes \\
Country Controls & Yes & Yes & Yes & Yes & Yes & Yes & Yes & Yes \\
\hline Observations & 456,884 & 384,529 & 440,172 & 441,059 & 439,892 & 464,709 & 454,115 & 372,078 \\
R-squared & 0.066 & 0.064 & 0.062 & 0.064 & 0.068 & 0.066 & 0.064 & 0.046 \\
Number of i & 91,082 & 82,585 & 90,817 & 90,305 & 89,616 & 92,333 & 91,214 & 85,385 \\
\hline
\end{tabular}

Standard errors are clustered within destination country.

All regressions include firm fixed effects.

$* * * p<0,01 ; * * p<0,05 ; * p<0,1$.

Table 11 - Intensive margin estimations: robustness check using bins from HS-2 specific size distribution.

\begin{tabular}{lcccccccc}
\hline \hline & \multicolumn{7}{c}{ Dep. Variable: Firm export per product (in log) } \\
\hline & $\begin{array}{c}\text { Information } \\
\text { Availability }\end{array}$ & $\begin{array}{c}\text { Advance } \\
\text { Ruling }\end{array}$ & $\begin{array}{c}\text { Appeal } \\
\text { Procedure }\end{array}$ & $\begin{array}{c}\text { Fees and } \\
\text { Charges }\end{array}$ & $\begin{array}{c}\text { Formalities } \\
\text { Document }\end{array}$ & $\begin{array}{c}\text { Formalities } \\
\text { Automation }\end{array}$ & $\begin{array}{c}\text { Formalities } \\
\text { Procedures }\end{array}$ & $\begin{array}{c}\text { Border agency } \\
\text { (Int. + ext.) }\end{array}$ \\
\hline TFI (log)*Small Size & $0.464 * *$ & $0.401^{* * *}$ & 0.095 & -0.069 & $-0.453^{* * *}$ & $-0.184 * *$ & 0.017 & -0.068 \\
& $(0.195)$ & $(0.104)$ & $(0.079)$ & $(0.117)$ & $(0.109)$ & $(0.078)$ & $(0.130)$ & $(0.100)$ \\
TFI (log)*Medium Size & 0.201 & 0.173 & -0.125 & 0.089 & -0.053 & -0.064 & -0.054 & 0.190 \\
& $(0.166)$ & $(0.155)$ & $(0.124)$ & $(0.146)$ & $(0.132)$ & $(0.123)$ & $(0.183)$ & $(0.120)$ \\
TFI $(\log ) *$ Big Size & -0.015 & -0.120 & -0.177 & 0.211 & 0.232 & 0.162 & -0.216 & $0.301 * *$ \\
& $(0.202)$ & $(0.219)$ & $(0.258)$ & $(0.207)$ & $(0.168)$ & $(0.148)$ & $(0.187)$ & $(0.146)$ \\
\hline Firm FE & Yes & Yes & Yes & Yes & Yes & Yes & Yes & Yes \\
Country Controls & Yes & Yes & Yes & Yes & Yes & Yes & Yes & Yes \\
\hline Observations & 456,884 & 384,529 & 440,172 & 441,059 & 439,892 & 464,709 & 454,115 & 372,078 \\
R-squared & 0.041 & 0.043 & 0.038 & 0.040 & 0.042 & 0.041 & 0.039 & 0.030 \\
Number of i & 91,082 & 82,585 & 90,817 & 90,305 & 89,616 & 92,333 & 91,214 & 85,385 \\
\hline
\end{tabular}

Standard errors are clustered within destination country.

All regressions include firm fixed effects.

*** $p<0,01 ; * * p<0,05 ; * p<0,1$. 
Table 12 - Export diversification estimations.

\begin{tabular}{lcccccccc}
\hline \hline & \multicolumn{7}{c}{ Dep. Variable: Herfindahl index } \\
\hline & $\begin{array}{c}\text { Information } \\
\text { Availability }\end{array}$ & $\begin{array}{c}\text { Advance } \\
\text { Ruling }\end{array}$ & $\begin{array}{c}\text { Appeal } \\
\text { Procedure }\end{array}$ & $\begin{array}{c}\text { Fees and } \\
\text { Charges }\end{array}$ & $\begin{array}{c}\text { Formalities } \\
\text { Document }\end{array}$ & $\begin{array}{c}\text { Formalities } \\
\text { Automation }\end{array}$ & $\begin{array}{c}\text { Formalities } \\
\text { Procedures }\end{array}$ & $\begin{array}{c}\text { Border agency } \\
\text { (Int. + ext.) }\end{array}$ \\
\hline TFI (log)*Small Size & $-0.047^{* * *}$ & $-0.034^{* * *}$ & $-0.016^{* * *}$ & -0.009 & -0.014 & -0.002 & -0.009 & -0.004 \\
& $(0.017)$ & $(0.011)$ & $(0.006)$ & $(0.008)$ & $(0.009)$ & $(0.006)$ & $(0.008)$ & $(0.007)$ \\
TFI (log)*Medium Size & $-0.044^{* * *}$ & $-0.024^{* *}$ & -0.011 & -0.005 & $-0.019^{* *}$ & -0.009 & -0.007 & -0.010 \\
& $(0.016)$ & $(0.010)$ & $(0.008)$ & $(0.008)$ & $(0.009)$ & $(0.008)$ & $(0.010)$ & $(0.008)$ \\
TFI (log)*Big Size & -0.019 & -0.012 & -0.008 & -0.013 & $-0.032 * * *$ & $-0.022^{* *}$ & 0.000 & -0.012 \\
& $(0.012)$ & $(0.013)$ & $(0.016)$ & $(0.013)$ & $(0.011)$ & $(0.008)$ & $(0.010)$ & $(0.008)$ \\
\hline Firm FE & Yes & Yes & Yes & Yes & Yes & Yes & Yes & Yes \\
Country Controls & Yes & Yes & Yes & Yes & Yes & Yes & Yes & Yes \\
\hline Observations & 456,884 & 384,529 & 440,172 & 441,059 & 439,892 & 464,709 & 454,115 & 372,078 \\
R-squared & 0.023 & 0.022 & 0.021 & 0.021 & 0.022 & 0.022 & 0.022 & 0.016 \\
Number of i & 91,082 & 82,585 & 90,817 & 90,305 & 89,616 & 92,333 & 91,214 & 85,385 \\
\hline
\end{tabular}

Standard errors are clustered within destination country.

All regressions include firm fixed effects and country controls.

$* * * p<0,01 ; * * p<0,05 ; * p<0,1$

Table 13 - Export Behavior of Small firms

\begin{tabular}{lc|c}
\hline \hline & $\begin{array}{c}\text { Share of exports to } \\
\text { high corrupt countries }\end{array}$ & $\begin{array}{c}\operatorname{Pr}(\text { Dummy=1 if the main } \\
\text { destination is high corrupt })\end{array}$ \\
\hline Small Size & $0.030^{* * *}$ & $0.050^{* * *}$ \\
& $(0.004)$ & $(0.005)$ \\
Medium Size & -0.001 & $0.016^{* * *}$ \\
& $(0.004)$ & $(0.005)$ \\
\hline Observations & 92372 & 92372 \\
\hline \hline
\end{tabular}

Results here are from OLS regressions where the unit of observation if the firm.

Share of firm's exports to high corrupt country (and dummy for having

high corrupt country as main destination) is regressed against firms size bins.

Big Size is the omitted category. Robust standard errors.

$* * * p<0,01 ; * * p<0,05 ; * p<0,1$. 
Table 14 - Estimations on low-corruption and ASYCUDA implementing countries

\begin{tabular}{lcccccc}
\hline & \multicolumn{3}{c}{ Formalities Documents } & \multicolumn{3}{c}{ Formalities Automation } \\
\hline & Export & Extensive & Intensive & Export & Extensive & Intensive \\
\hline TFI $(\mathrm{log})^{*}$ Small Size & -0.077 & 0.045 & -0.121 & 0.117 & 0.089 & 0.027 \\
& $(0.237)$ & $(0.077)$ & $(0.204)$ & $(0.296)$ & $(0.089)$ & $(0.223)$ \\
TFI $(\mathrm{log})^{*}$ Medium Size & $0.565^{* *}$ & $0.207^{* *}$ & 0.357 & 0.281 & 0.084 & 0.197 \\
& $(0.237)$ & $(0.077)$ & $(0.217)$ & $(0.283)$ & $(0.072)$ & $(0.229)$ \\
TFI $(\mathrm{log}) *$ Big Size & $1.205^{* * *}$ & $0.456^{* * *}$ & $0.748^{* * *}$ & 0.567 & 0.228 & 0.339 \\
& $(0.314)$ & $(0.112)$ & $(0.250)$ & $(0.447)$ & $(0.141)$ & $(0.323)$ \\
\hline Firm FE & yes & yes & yes & yes & yes & yes \\
Country Controls & yes & yes & yes & yes & yes & yes \\
\hline Observations & 319,910 & 319,910 & 319,910 & 319,965 & 319,965 & 319,965 \\
R-squared & 0.079 & 0.068 & 0.045 & 0.073 & 0.062 & 0.042 \\
Number of i & 77,076 & 77,076 & 77,076 & 77,095 & 77,095 & 77,095 \\
\hline \hline
\end{tabular}

Standard errors are clustered within destination country.

All regressions include firm fixed effects and country controls.

$* * * p<0,01 ; * * p<0,05 ; * p<0,1$.

Table 15 - Weighted OLS estimations using firms' export share into high corrupt, noASYCUDA, with NGOs' presence countries as weight

\begin{tabular}{lcccccc}
\hline & \multicolumn{3}{c}{ Formalities Documents } & \multicolumn{3}{c}{ Formalities Automation } \\
\hline & Export & Extensive & Intensive & Export & Extensive & Intensive \\
\hline TFI $(\log )^{*}$ Small Size & $-0.847^{* * *}$ & $-0.084^{* *}$ & $-0.763^{* * *}$ & $-0.441^{* * *}$ & $-0.051^{* * *}$ & $-0.390^{* * *}$ \\
& $(0.138)$ & $(0.039)$ & $(0.117)$ & $(0.084)$ & $(0.018)$ & $(0.078)$ \\
TFI $(\log )^{*}$ Medium Size & $-0.646^{* * *}$ & -0.063 & $-0.582^{* * *}$ & $-0.472^{* *}$ & $-0.081^{* *}$ & $-0.391^{* *}$ \\
& $(0.178)$ & $(0.042)$ & $(0.153)$ & $(0.184)$ & $(0.032)$ & $(0.165)$ \\
TFI $(\log ) *$ Big Size & 0.106 & $0.136^{* *}$ & -0.029 & 0.078 & 0.060 & 0.017 \\
& $(0.221)$ & $(0.065)$ & $(0.171)$ & $(0.189)$ & $(0.047)$ & $(0.158)$ \\
\hline Firm FE & yes & yes & yes & yes & yes & yes \\
Country Controls & yes & yes & yes & yes & yes & yes \\
\hline Observations & 281,850 & 281,850 & 281,850 & 304,698 & 304,698 & 304,698 \\
R-squared & 0.033 & 0.030 & 0.026 & 0.031 & 0.025 & 0.024 \\
Number of i & 27,867 & 27,867 & 27,867 & 29,756 & 29,756 & 29,756 \\
\hline \hline
\end{tabular}

Standard errors are clustered within destination country.

All regressions include firm fixed effects and country controls.

$* * * \quad p<0,01 ; * * p<0,05 ; * p<0,1$. 
Figure 9 - Distribution of firms exports before and after the adoption of region best practice in TF by each destination country. Lorenz curves (right) and Kernel densities (left).

Information Availability
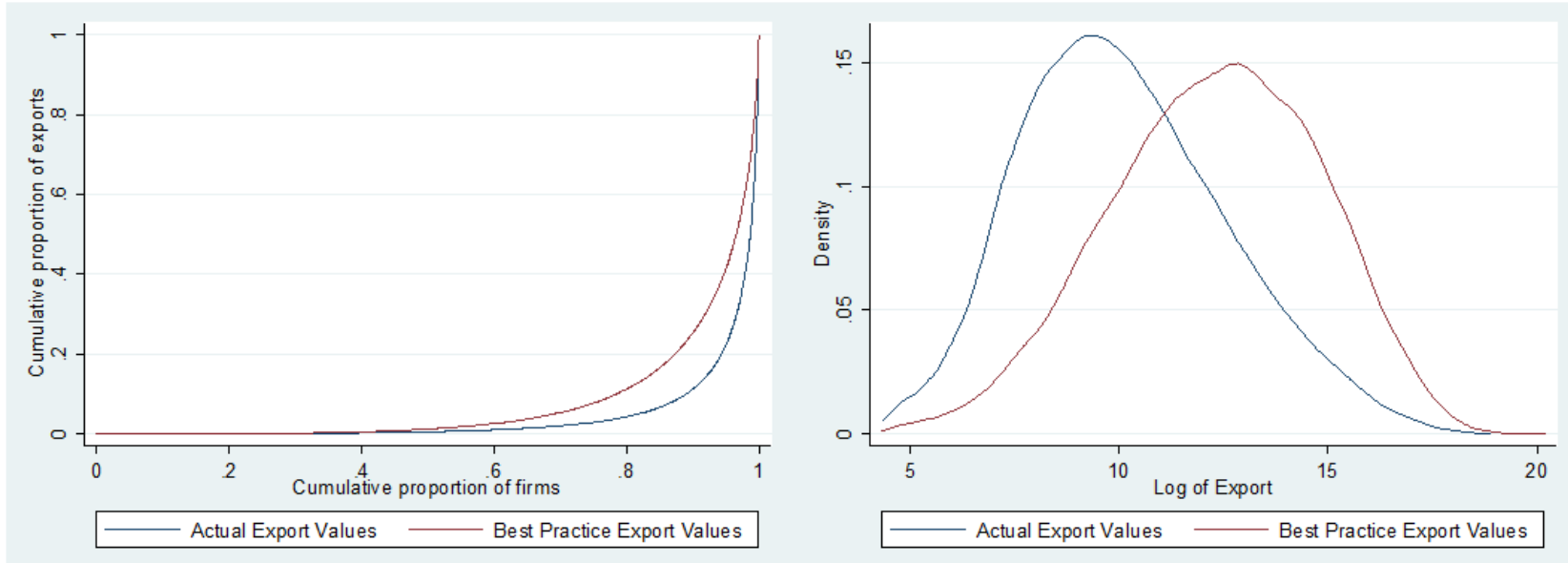

Advance Ruling
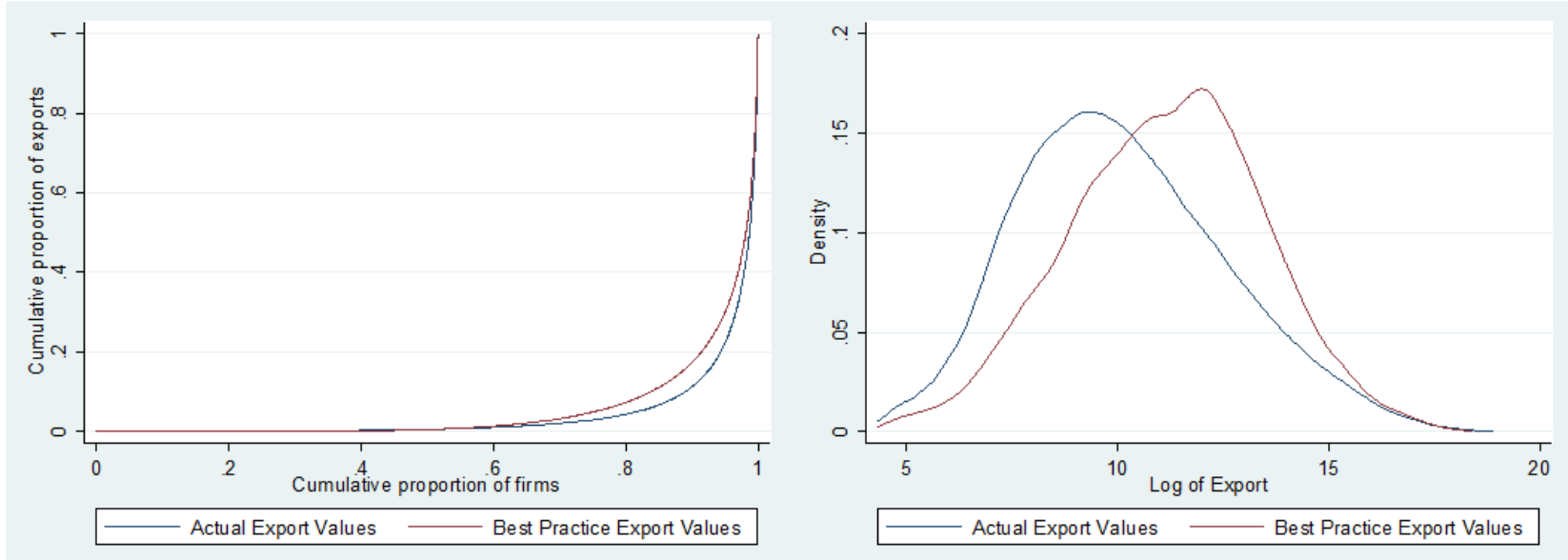

Appeal Procedure
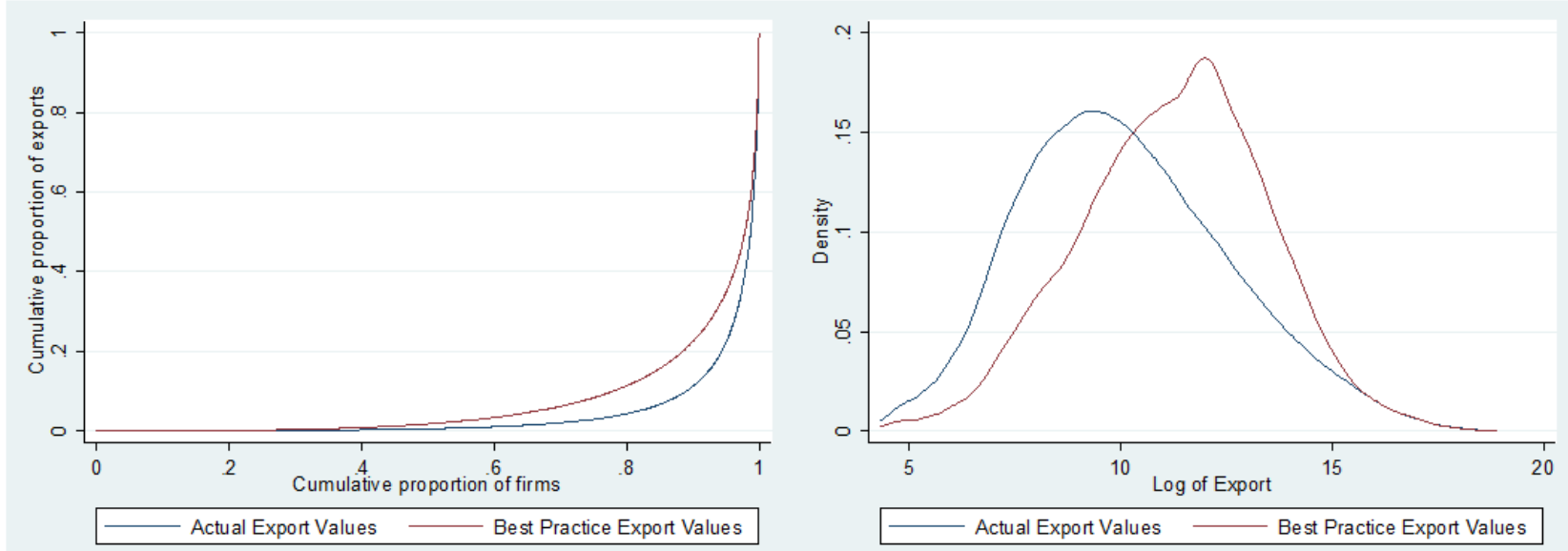


\section{Fees and Charges}
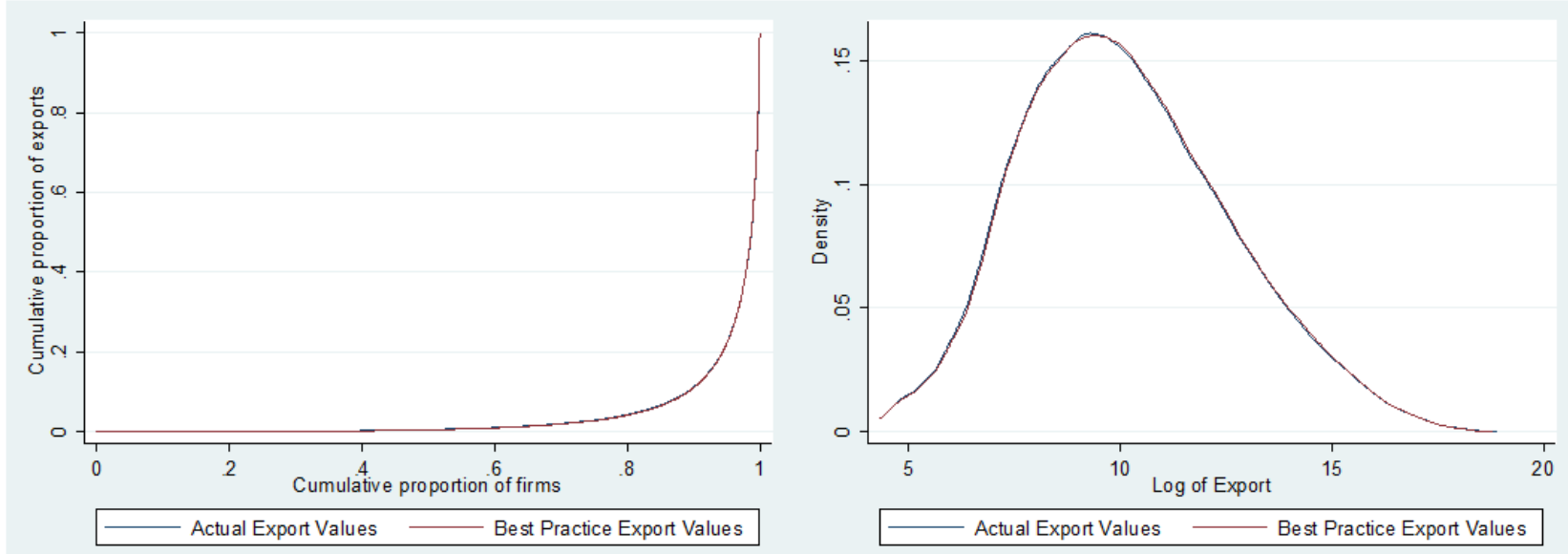

Formalities Documents
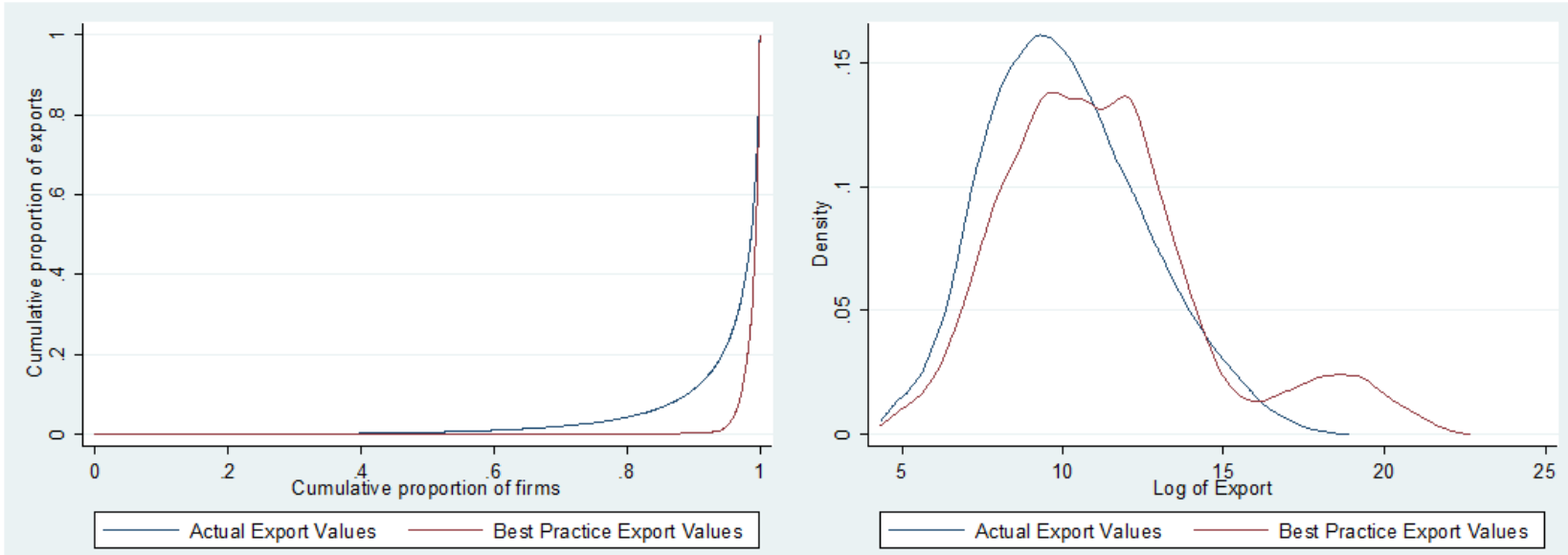

Formalities Automation
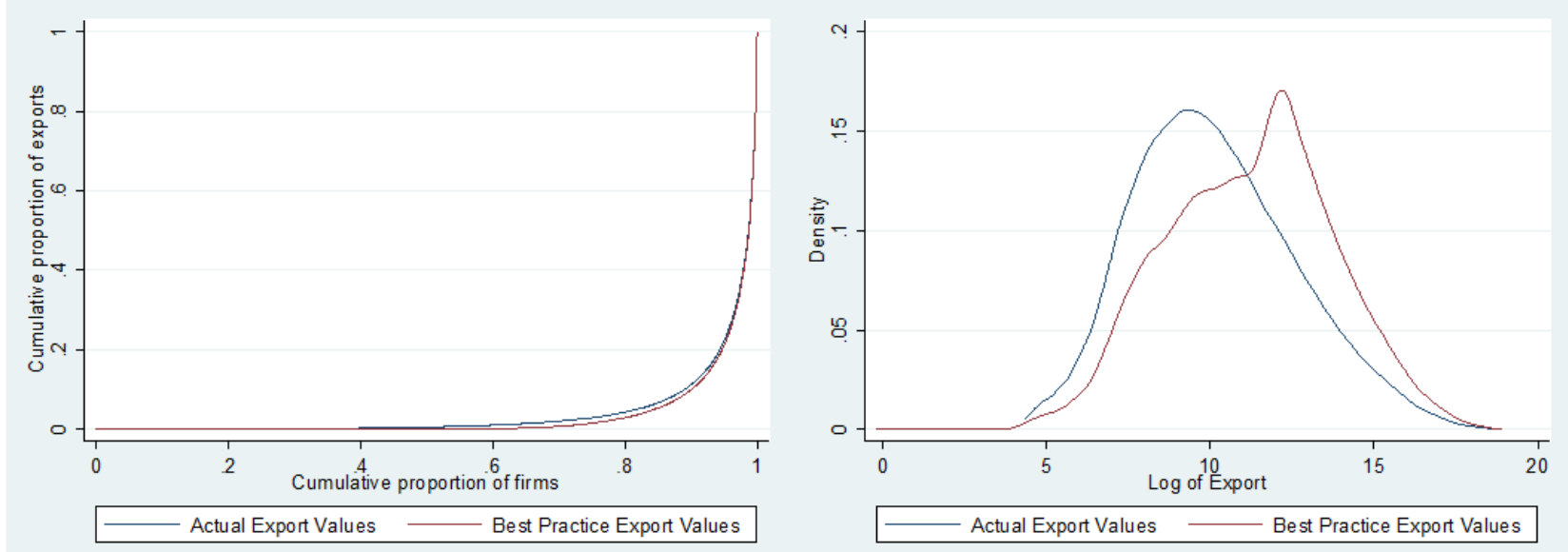


\section{Formalities Procedures}
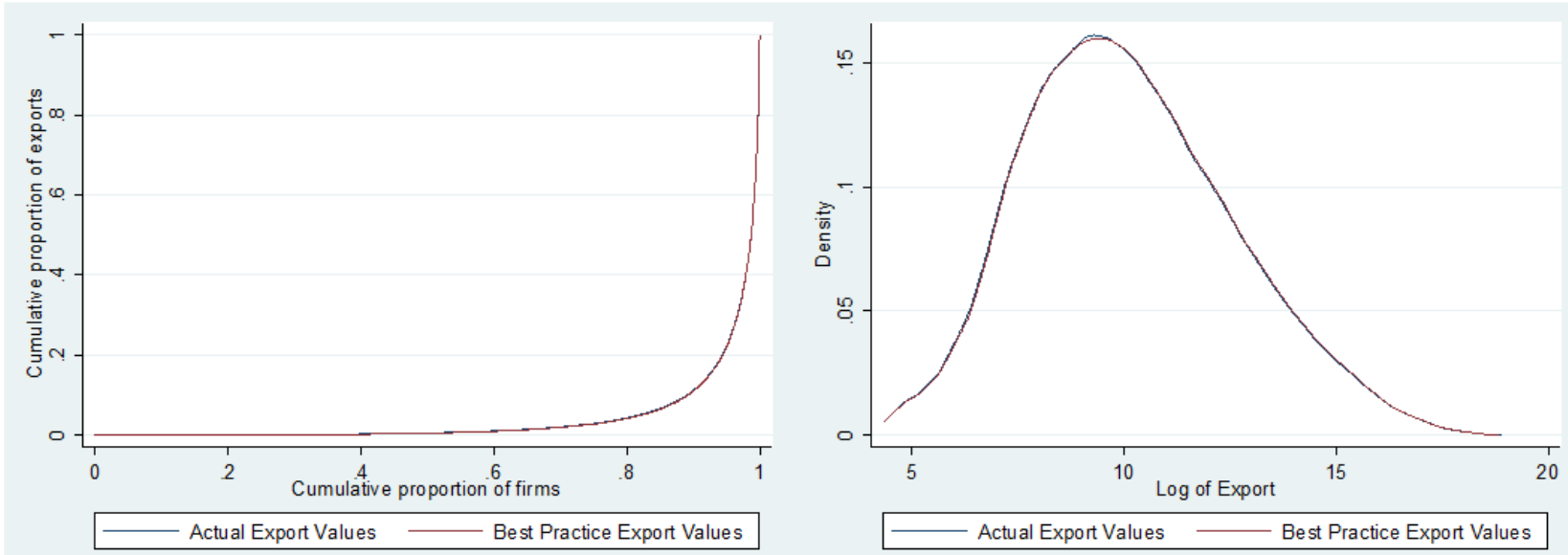

\section{Border Agency Cooperation}
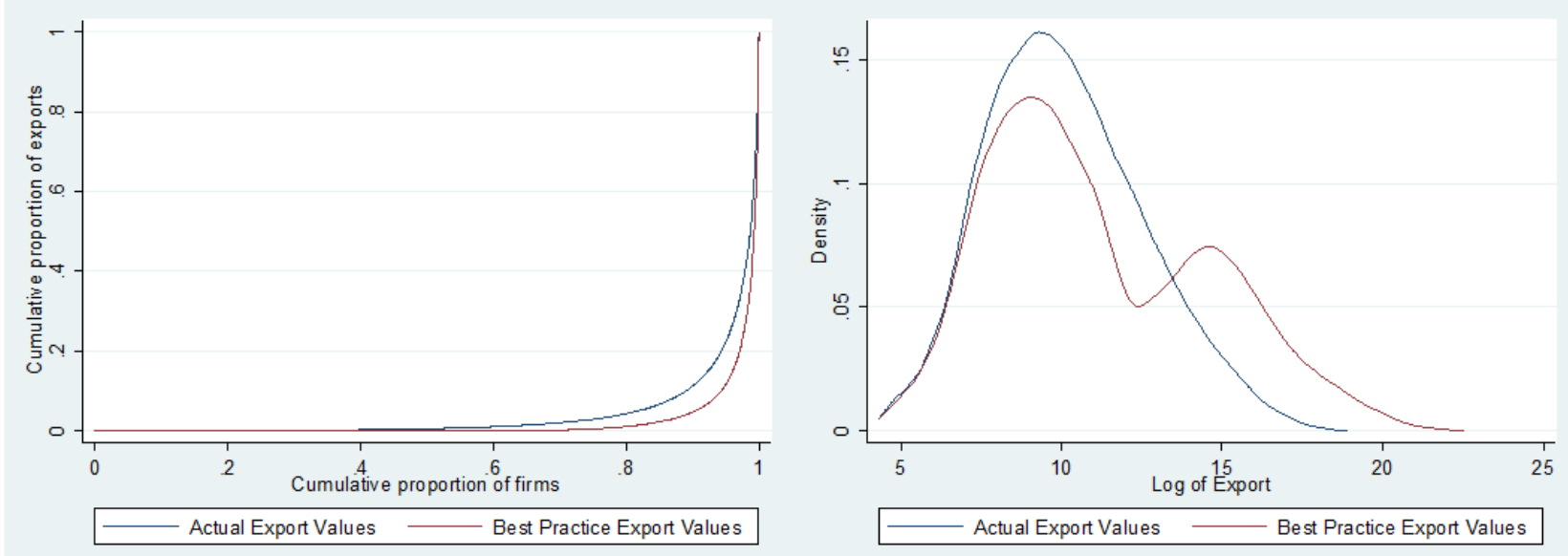

Notes: Actual Export Value represents the distribution of total exports of firms in the ex-ante situation (before any improvement in the TF). Best Practice Export Values represents the distribution of total exports of firms if each destination country adopts the TF best practice in its region. Such calculation uses the estimated coefficients reported in table 3 . 


\section{Appendix}

Figure A1 - Number of exported products and average TFI by country. OECD countries excluded.

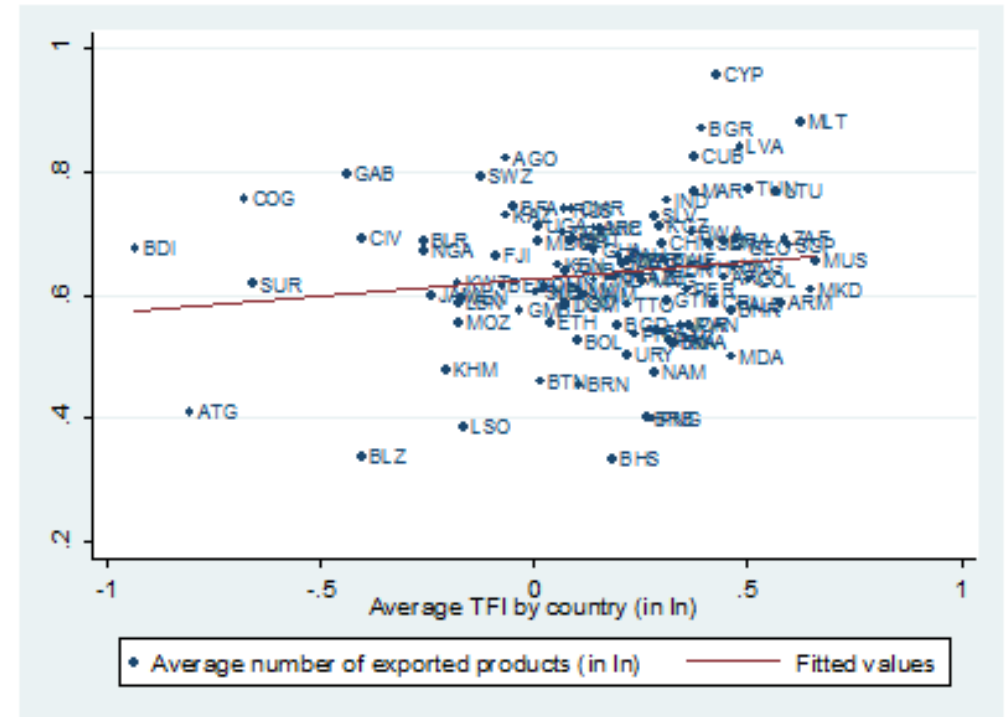

Source: Authors calculations on TFI database, OECD

Figure A2 - Exported values and average TFI by country. OECD countries excluded.

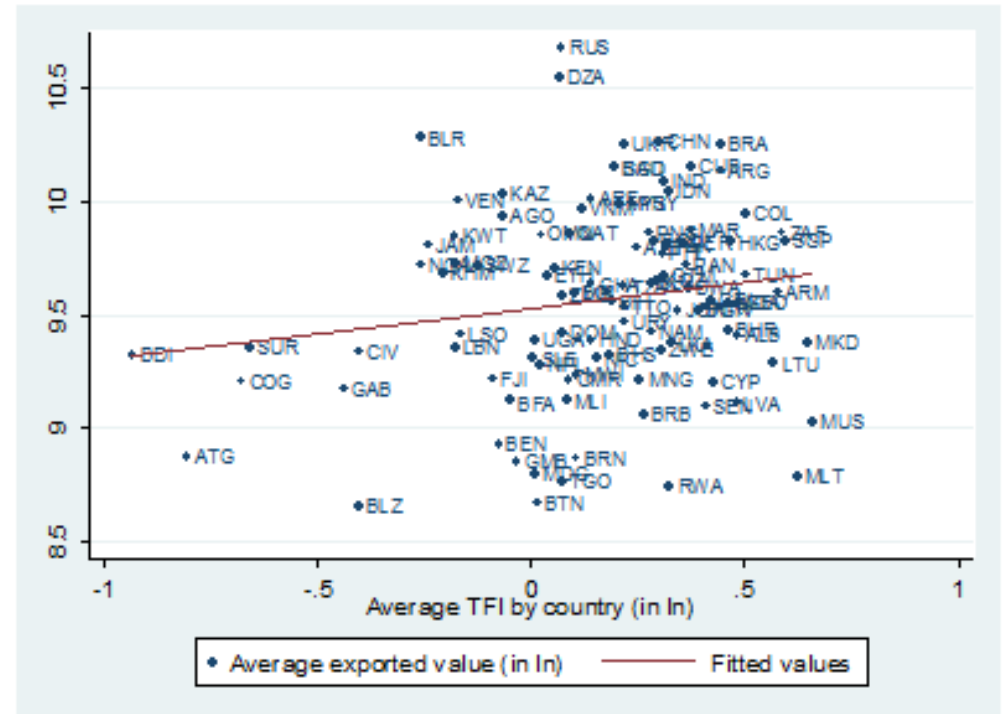

Source: Authors calculations on TFI database, OECD 
Figure A3 - Number of exported products and average TFI by country. TFI values conditioned on per capita GDP

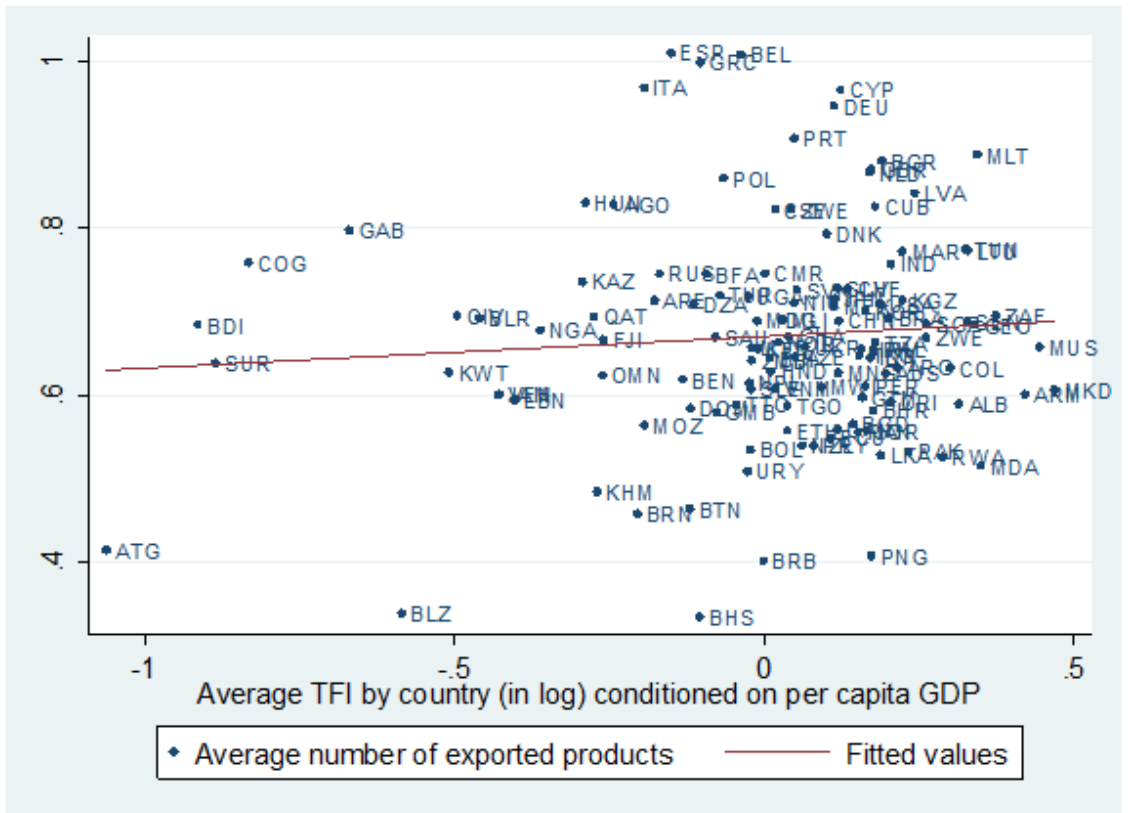

Source: Authors calculations on TFI database, OECD

Figure A4 - Exported values and average TFI by country. TFI values conditioned on per capita GDP

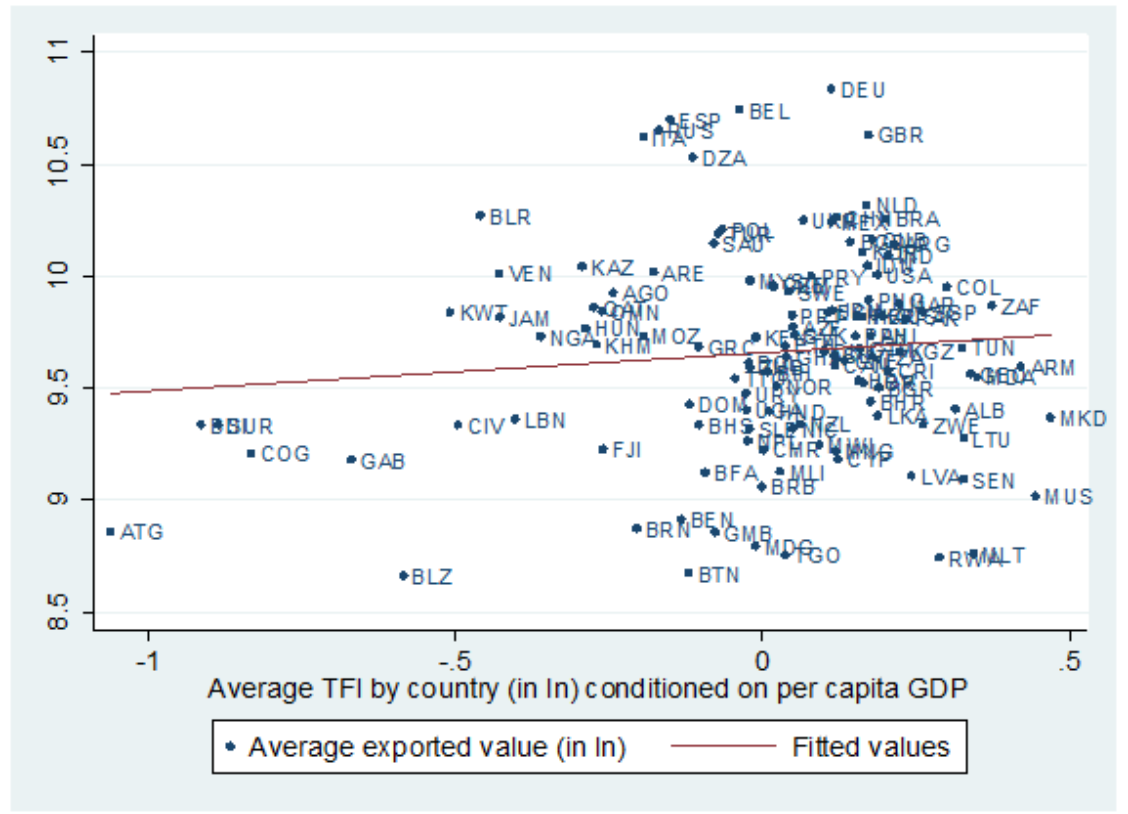

Source: Authors calculations on TFI database, OECD 
Figure A5 - Correlation between GDP, NGOs activism and corruption index
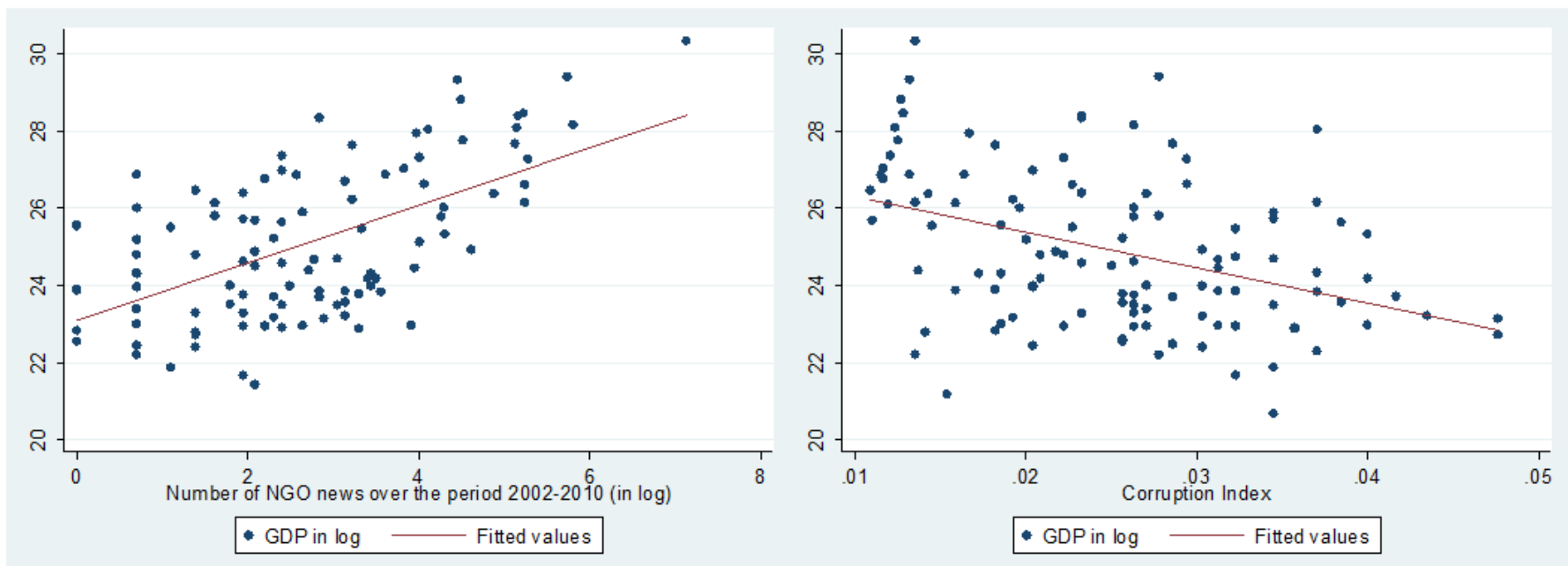

Source: Authors calculations on TFI database, OECD 


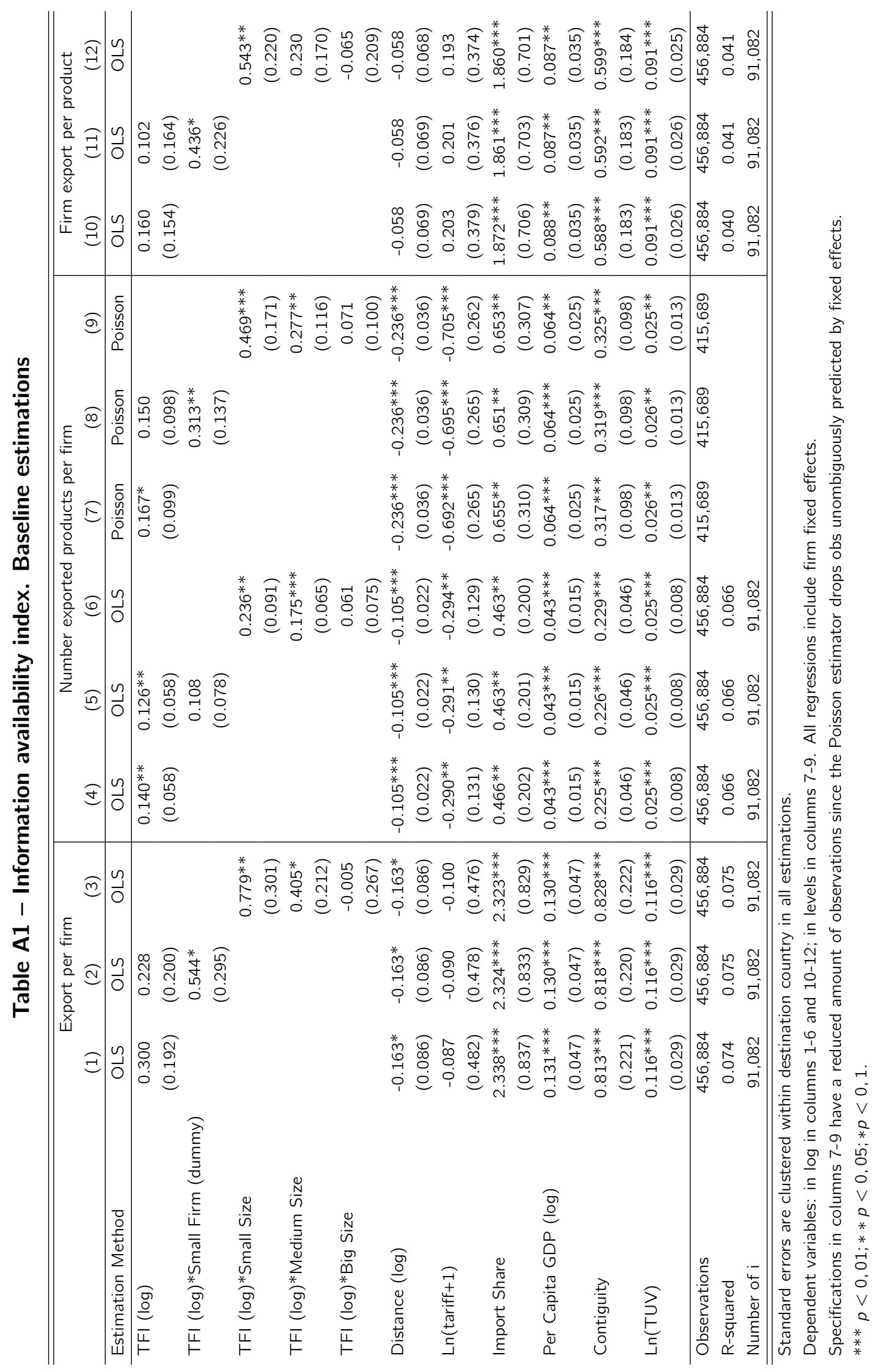




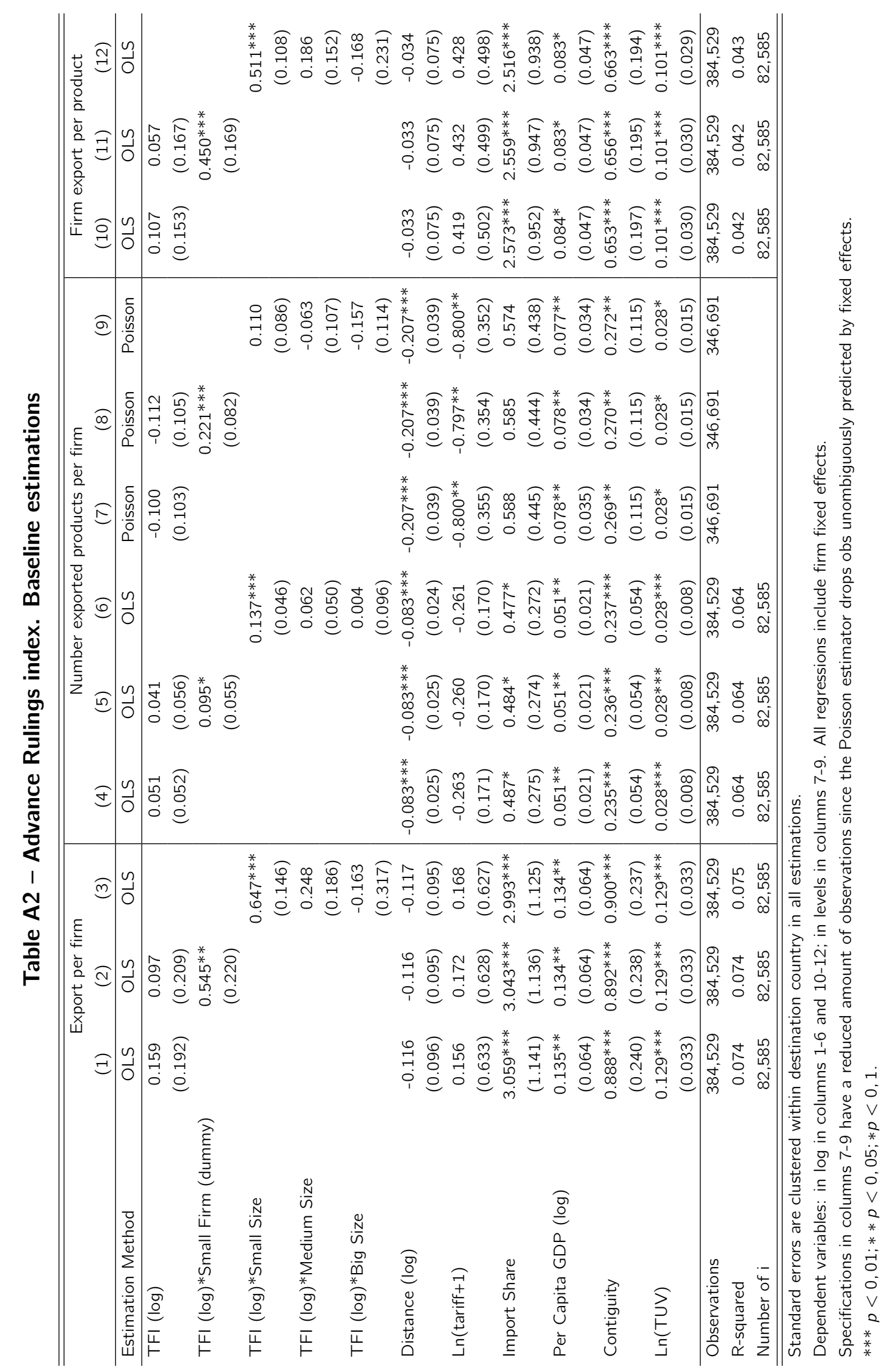




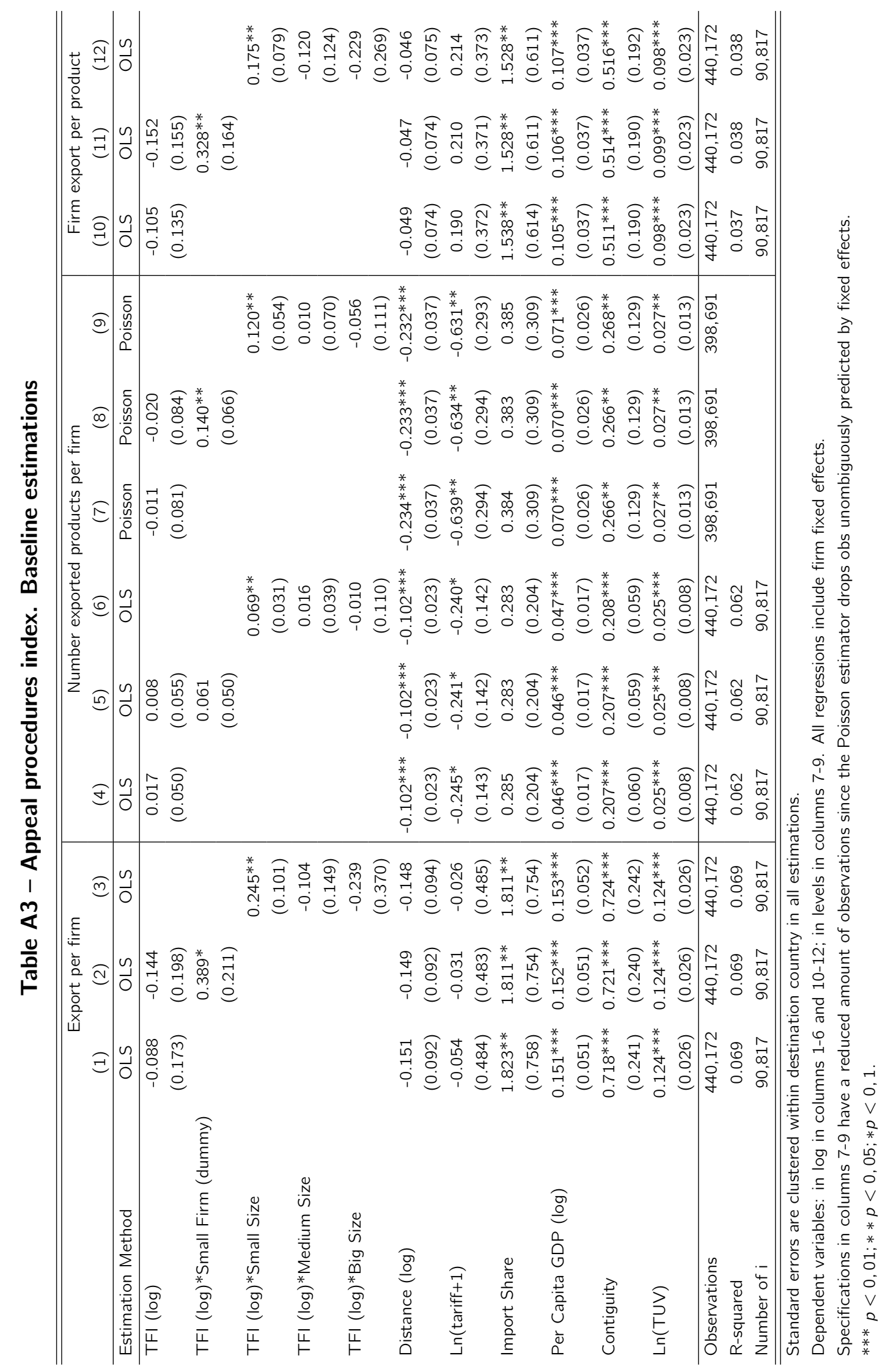




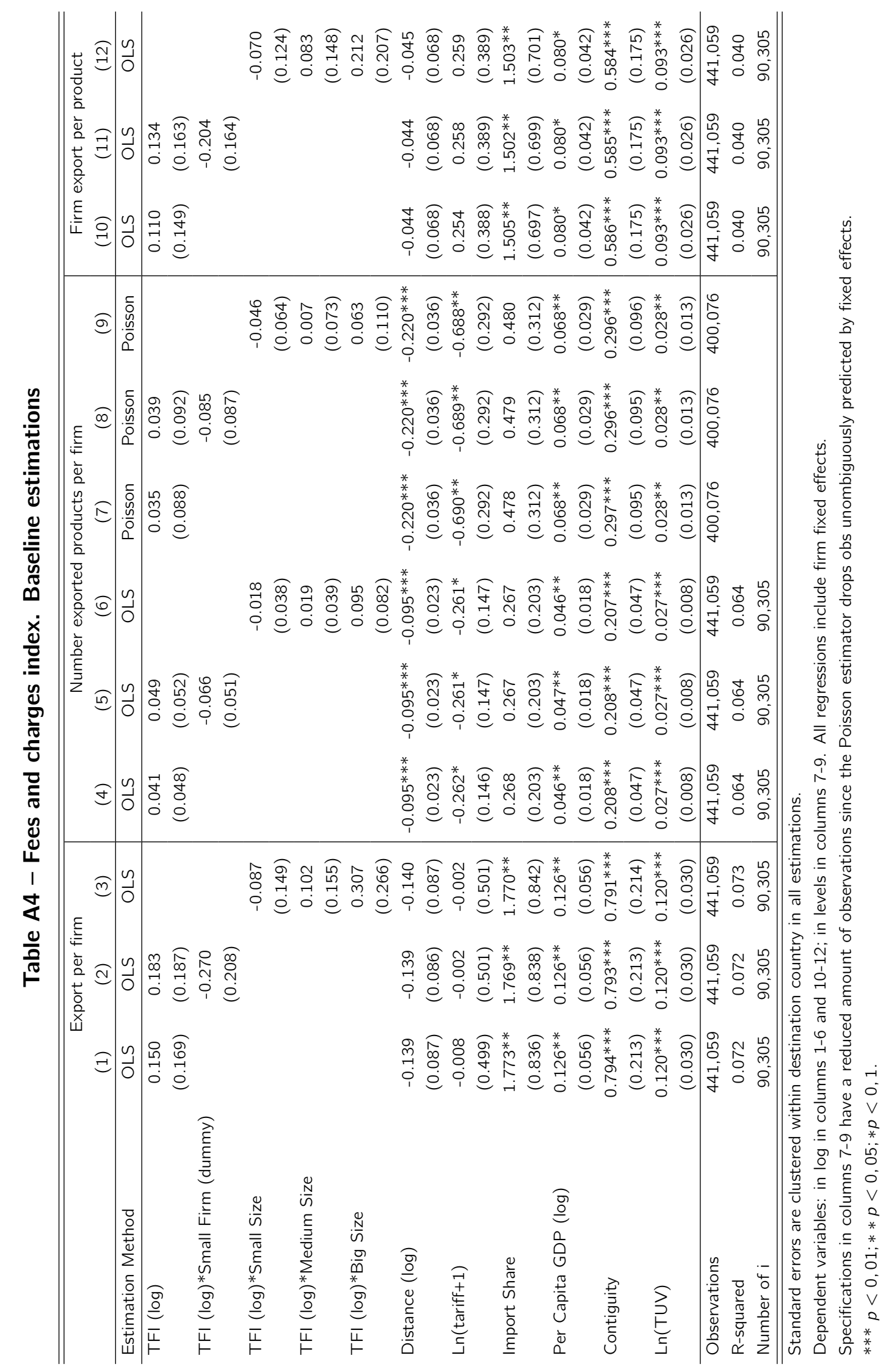




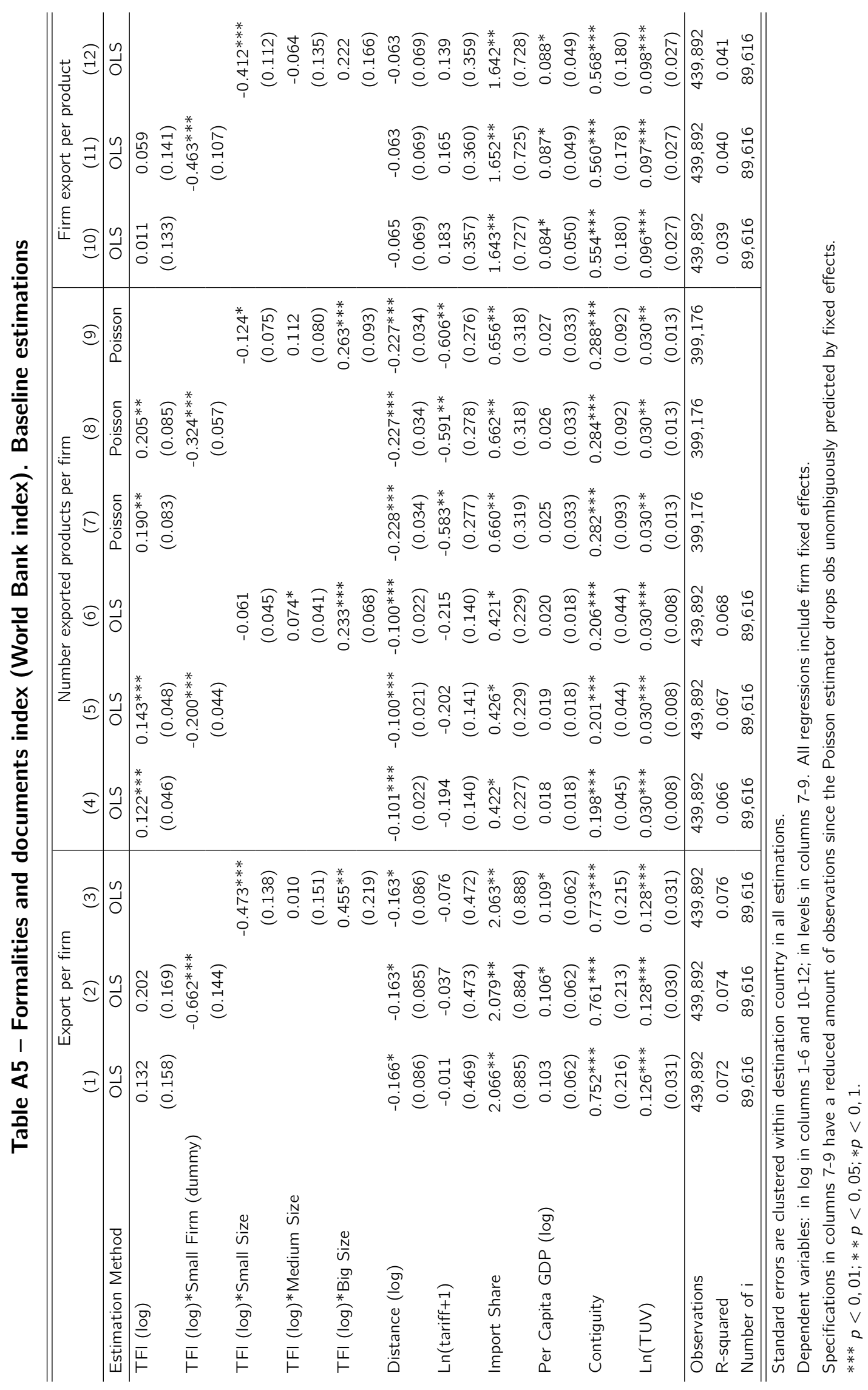




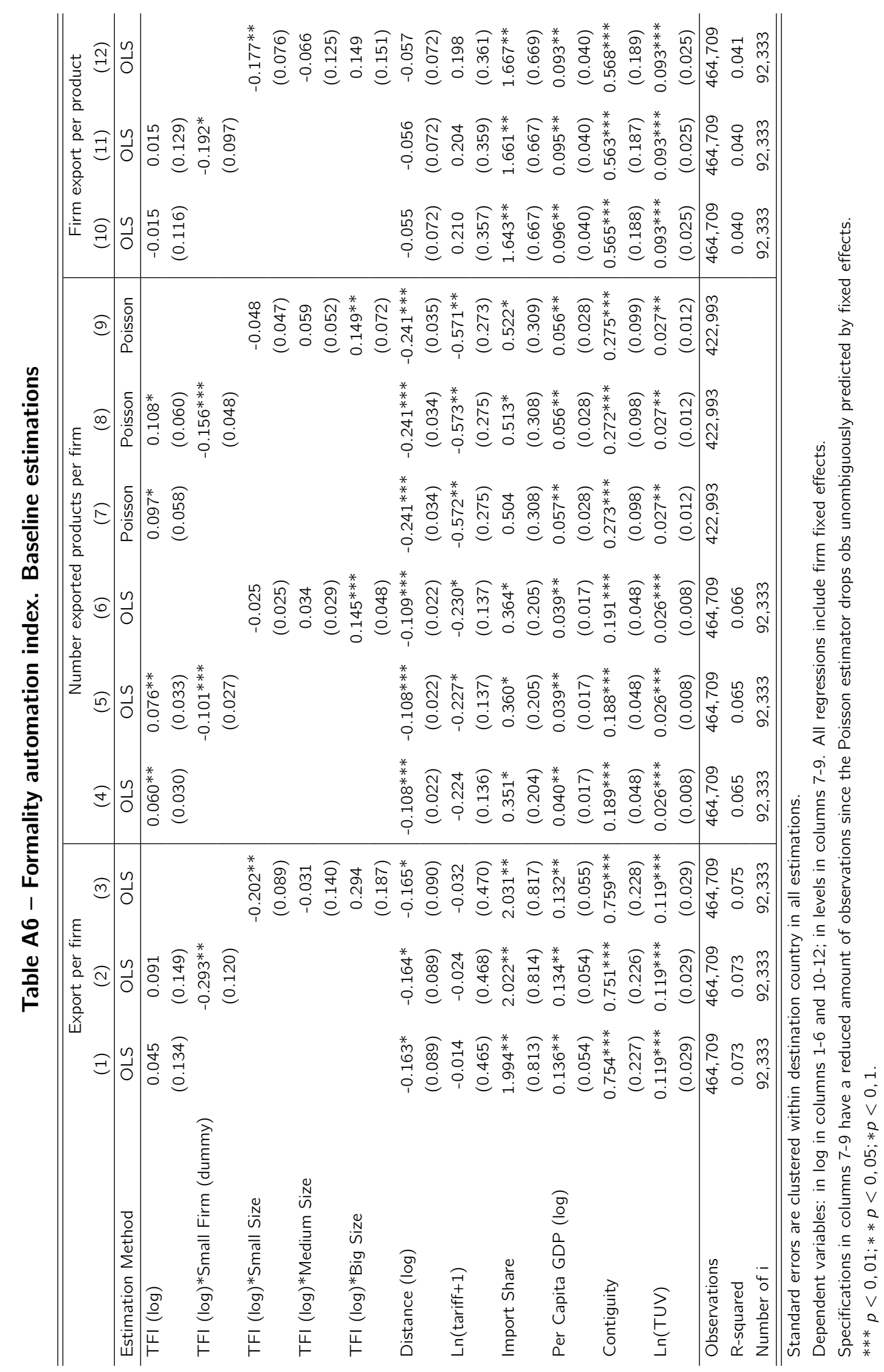




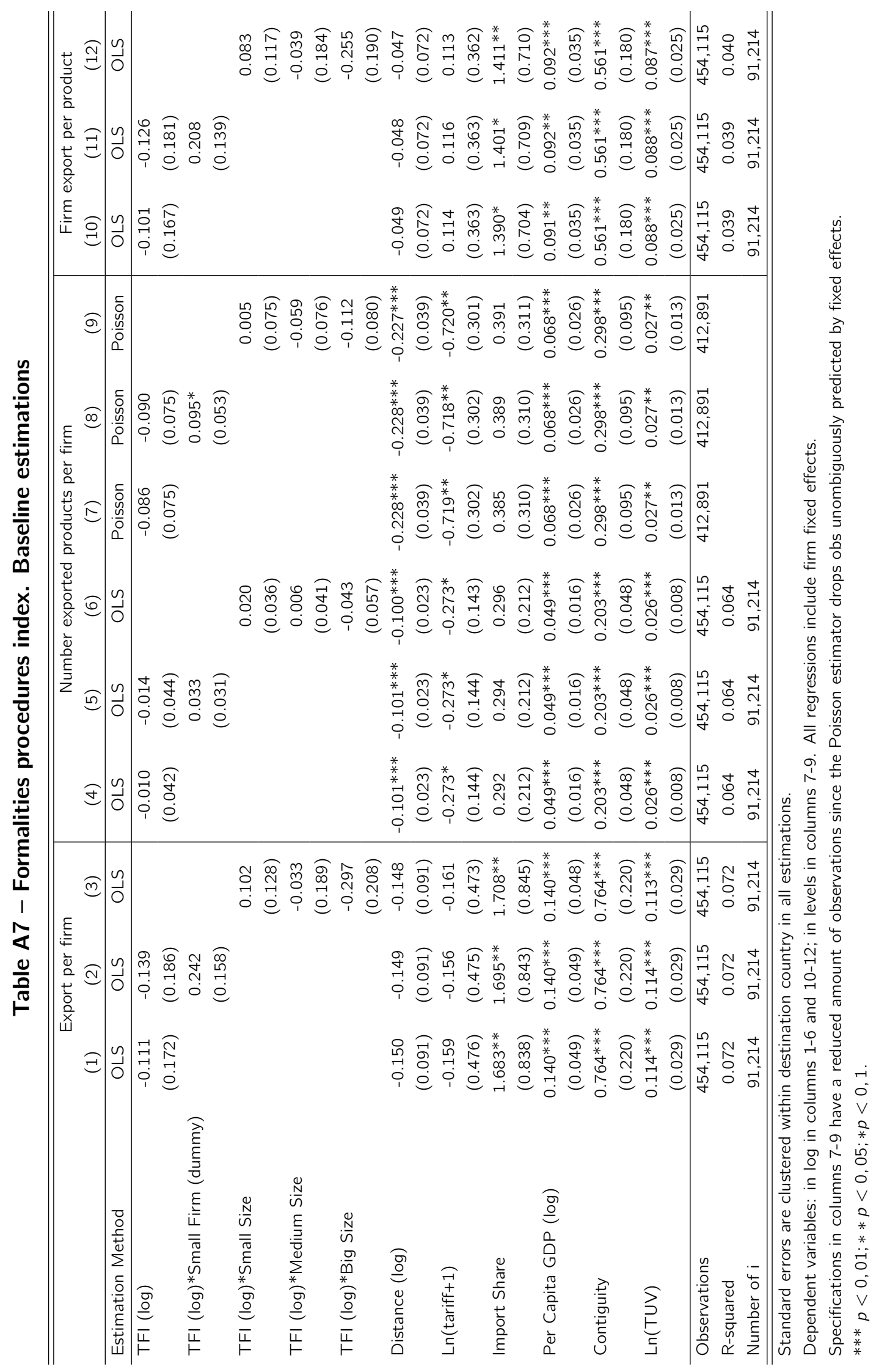




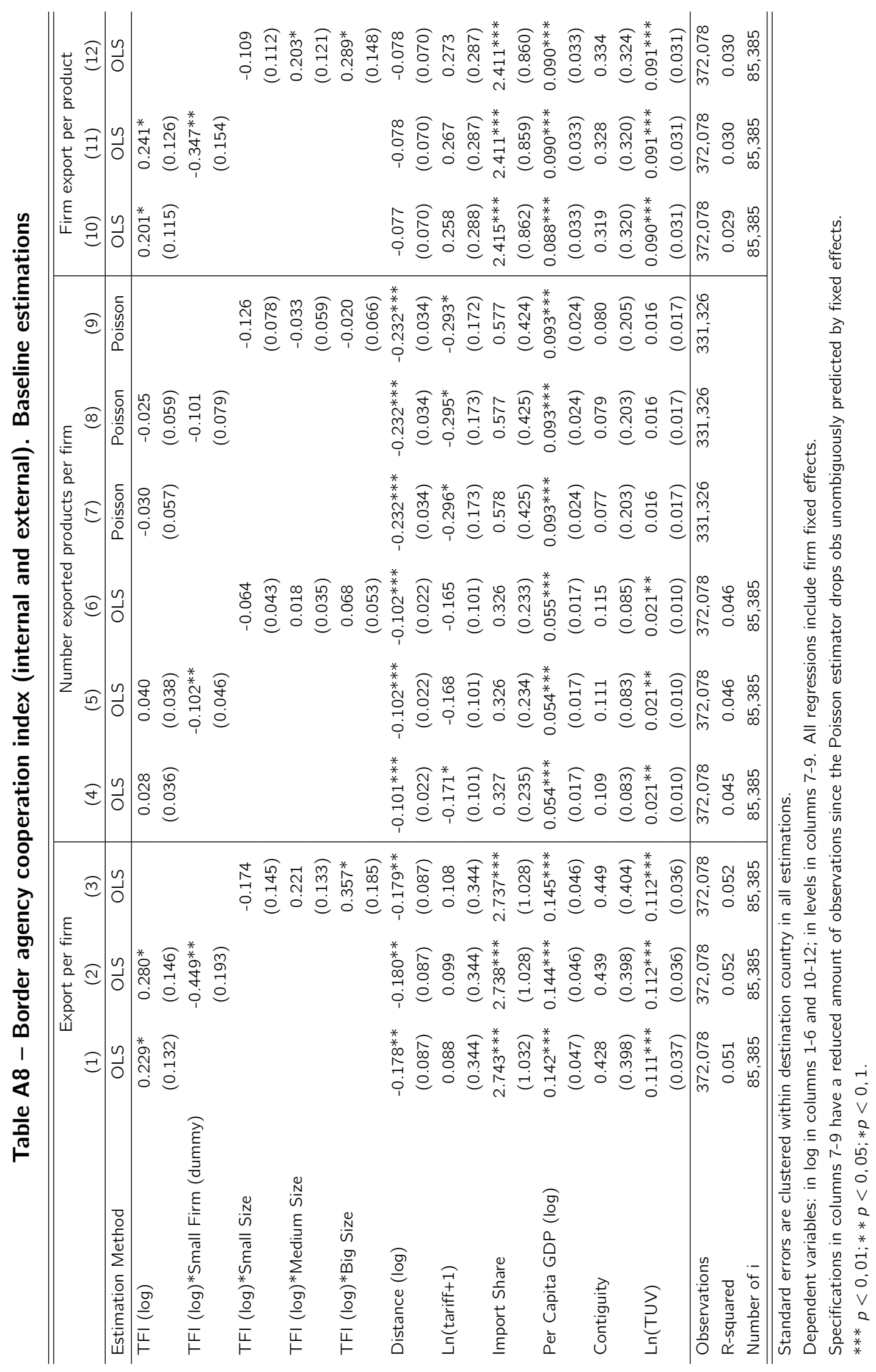




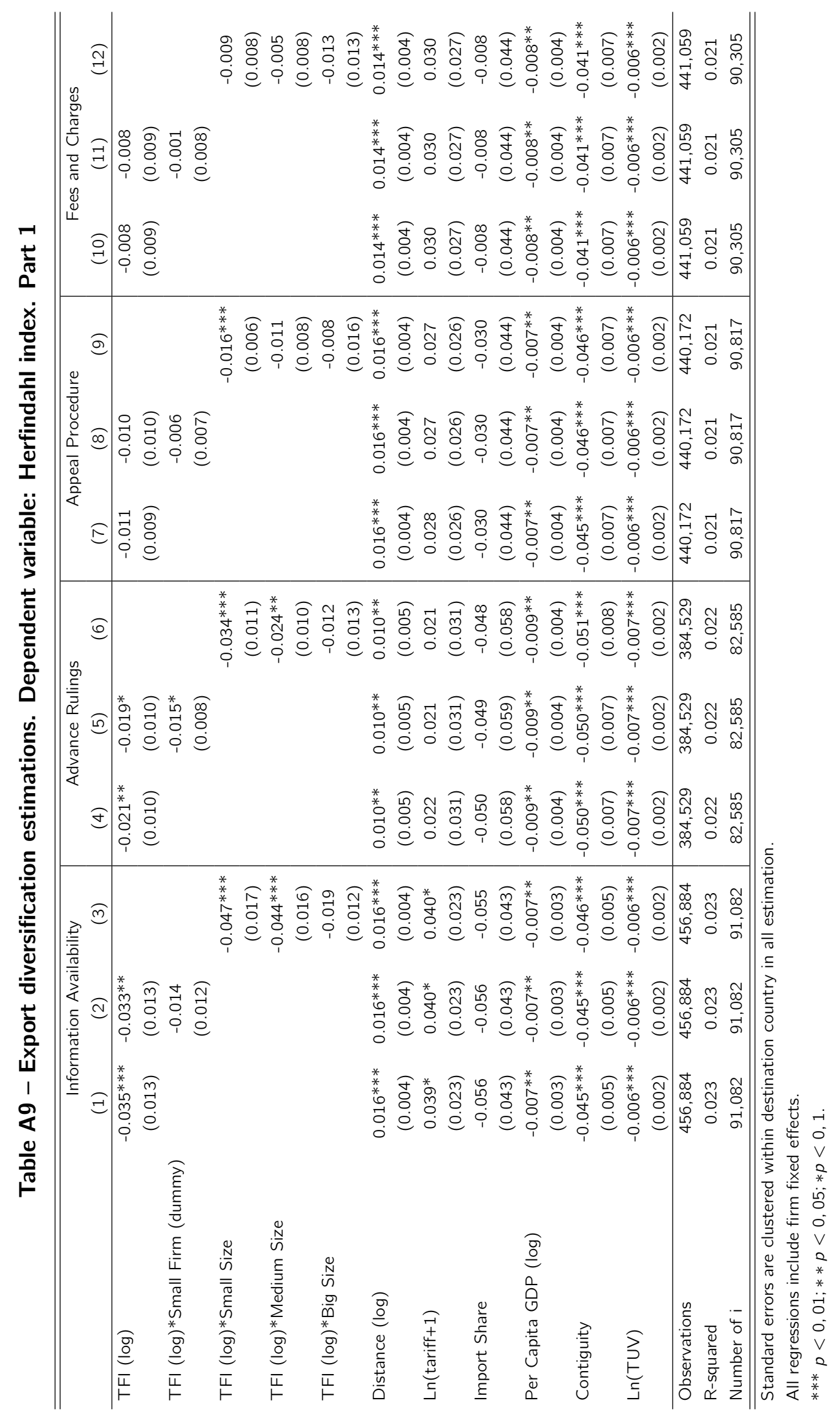




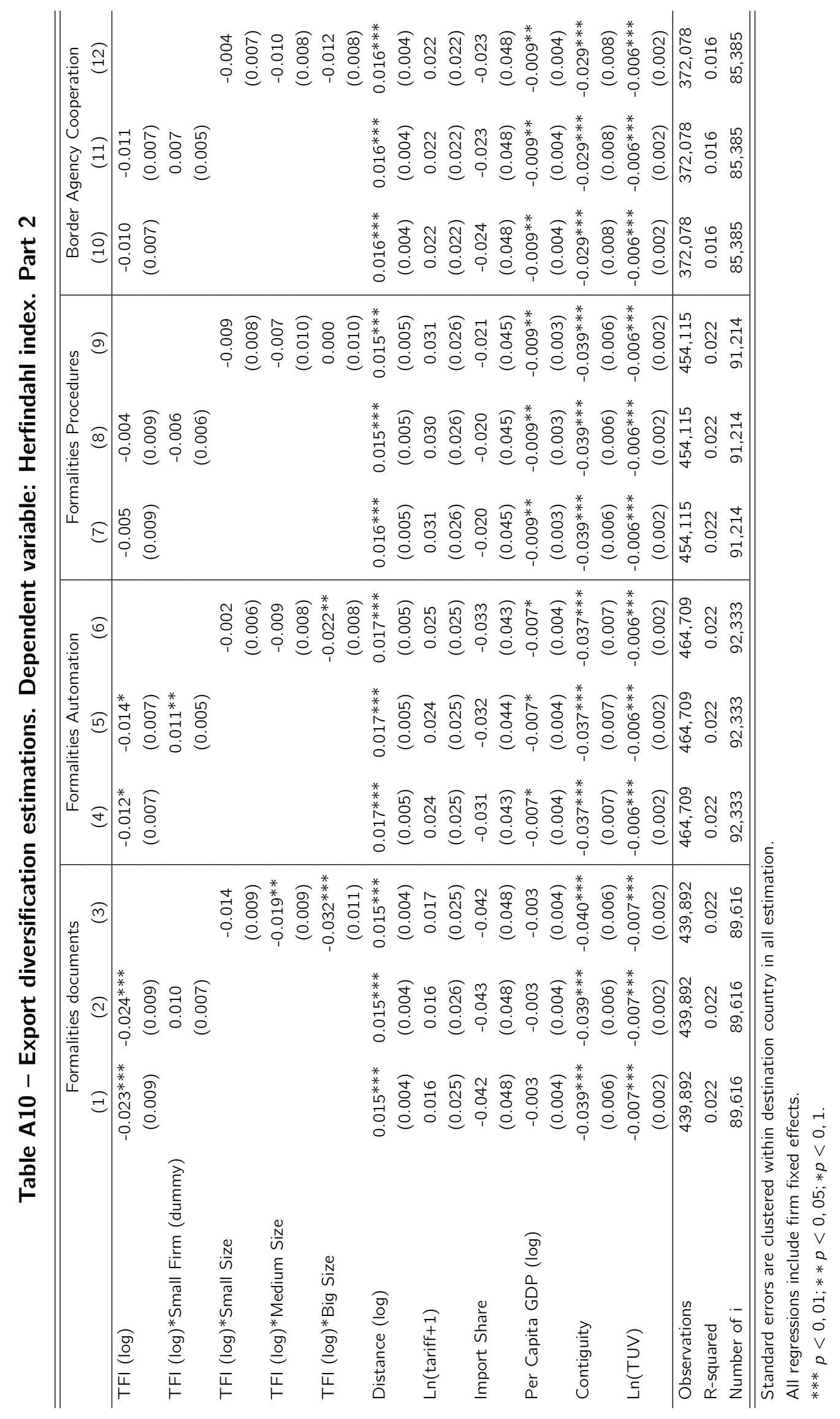


Table A11 - Total export estimations. Robustness using country Fixed Effects

\begin{tabular}{lcccccccc}
\hline \hline & \multicolumn{7}{c}{ Dep. Variable: Total export per firm (in log) } \\
\hline & Information & Advance & Appeal & Fees and & Formalities & Formalities & Formalities & Border agency \\
& Availability & Ruling & Procedure & Charges & Document & Automation & Procedures & (Int. + ext.) \\
\hline TFI (log)*Small Size & $0.092^{* *}$ & $0.271^{* * *}$ & $0.283^{* * *}$ & $-0.370^{* * *}$ & $-0.593^{* * *}$ & $-0.301^{* * *}$ & $0.151^{* * *}$ & $-0.353^{* * *}$ \\
& $(0.041)$ & $(0.034)$ & $(0.023)$ & $(0.029)$ & $(0.024)$ & $(0.018)$ & $(0.030)$ & $(0.025)$ \\
Ln(tariff+1) & $-0.631^{* * *}$ & $-0.564^{* * *}$ & $-0.654^{* * *}$ & $-0.624^{* * *}$ & $-0.654^{* * *}$ & $-0.636^{* * *}$ & $-0.635^{* * *}$ & $-0.596^{* * *}$ \\
& $(0.051)$ & $(0.059)$ & $(0.051)$ & $(0.053)$ & $(0.052)$ & $(0.051)$ & $(0.051)$ & $(0.054)$ \\
\hline Firm FE & Yes & Yes & Yes & Yes & Yes & Yes & Yes & Yes \\
Country FE & Yes & Yes & Yes & Yes & Yes & Yes & Yes & Yes \\
\hline Observations & 456,885 & 384,529 & 440,173 & 441,060 & 439,893 & 464,710 & 454,116 & 372,079 \\
R-squared & 0.508 & 0.523 & 0.510 & 0.513 & 0.512 & 0.508 & 0.509 & 0.519 \\
\hline
\end{tabular}

Robust standard errors.

All regressions include firm and country fixed effects.

*** $p<0,01 ; * * p<0,05 ; * p<0,1$.

Table A12 - Extensive margin estimations. Robustness using country Fixed Effects

\begin{tabular}{|c|c|c|c|c|c|c|c|c|}
\hline & \multicolumn{8}{|c|}{ Dep. Variable: Number of exported products per firm (in log) } \\
\hline & Information & Advance & Appeal & Fees and & Formalities & Formalities & Formalities & Border agency \\
\hline & Availability & Ruling & Procedure & Charges & Document & Automation & Procedures & $($ Int. + ext.) \\
\hline \multirow[t]{2}{*}{ TFI $(\log ) *$ Small Size } & -0.024 & 0.015 & $0.023 * *$ & $-0.074 * * *$ & $-0.176 * * *$ & $-0.097 * * *$ & $-0.025 * *$ & $-0.107^{* * *}$ \\
\hline & $(0.017)$ & $(0.013)$ & $(0.009)$ & $(0.012)$ & $(0.010)$ & $(0.007)$ & $(0.012)$ & $(0.010)$ \\
\hline \multirow[t]{2}{*}{$\operatorname{Ln}($ tariff +1$)$} & $-0.285 * * *$ & $-0.341 * * *$ & $-0.287 * * *$ & $-0.329 * * *$ & $-0.299 * * *$ & $-0.304 * * *$ & $-0.297 * * *$ & $-0.261 * * *$ \\
\hline & $(0.021)$ & $(0.024)$ & $(0.021)$ & $(0.022)$ & $(0.021)$ & $(0.021)$ & $(0.021)$ & $(0.022)$ \\
\hline Firm FE & Yes & Yes & Yes & Yes & Yes & Yes & Yes & Yes \\
\hline Country FE & Yes & Yes & Yes & Yes & Yes & Yes & Yes & Yes \\
\hline Observations & 456,885 & 384,529 & 440,173 & 441,060 & 439,893 & 464,710 & 454,116 & 372,079 \\
\hline R-squared & 0.550 & 0.581 & 0.546 & 0.556 & 0.556 & 0.548 & 0.551 & 0.542 \\
\hline
\end{tabular}

Robust standard errors.

All regressions include firm and country fixed effects.

$* * * p<0,01 ; * * p<0,05 ; * p<0,1$. 
Table A13 - Intensive margin estimations. Robustness using country Fixed Effects

\begin{tabular}{lcccccccc}
\hline \hline & \multicolumn{7}{c}{ Dep. Variable: Firm export per product (in log) } \\
\hline & Information & Advance & Appeal & Fees and & Formalities & Formalities & Formalities & Border agency \\
& Availability & Ruling & Procedure & Charges & Document & Automation & Procedures & (Int. + ext.) \\
\hline TFI (log)*Small Size & $0.116^{* * *}$ & $0.256^{* * *}$ & $0.260^{* * *}$ & $-0.296^{* * *}$ & $-0.417^{* * *}$ & $-0.204^{* * *}$ & $0.176^{* * *}$ & $-0.246^{* * *}$ \\
& $(0.037)$ & $(0.030)$ & $(0.020)$ & $(0.026)$ & $(0.022)$ & $(0.016)$ & $(0.026)$ & $(0.022)$ \\
Ln(tariff+1) & $-0.347^{* * *}$ & $-0.223^{* * *}$ & $-0.366^{* * *}$ & $-0.295^{* * *}$ & $-0.355^{* * *}$ & $-0.332^{* * *}$ & $-0.339^{* * *}$ & $-0.335^{* * *}$ \\
& $(0.045)$ & $(0.053)$ & $(0.045)$ & $(0.047)$ & $(0.046)$ & $(0.045)$ & $(0.045)$ & $(0.048)$ \\
\hline Firm FE & Yes & Yes & Yes & Yes & Yes & Yes & Yes & Yes \\
Country FE & Yes & Yes & Yes & Yes & Yes & Yes & Yes & Yes \\
\hline Observations & 456,885 & 384,529 & 440,173 & 441,060 & 439,893 & 464,710 & 454,116 & 372,079 \\
R-squared & 0.524 & 0.541 & 0.525 & 0.529 & 0.527 & 0.524 & 0.525 & 0.534 \\
\hline
\end{tabular}

Robust standard errors.

All regressions include firm and country fixed effects.

*** $p<0,01 ; * * p<0,05 ; * p<0,1$.

Table A14 - Estimations using the number of days to export as a proxy for the trade cost.

\begin{tabular}{|c|c|c|c|c|c|c|}
\hline & \multicolumn{3}{|c|}{ Number exported products } & \multicolumn{3}{|c|}{ Export per product } \\
\hline & (1) & (2) & (3) & $(4)$ & (5) & $(6)$ \\
\hline Estimation Method & OLS & OLS & OLS & OLS & OLS & OLS \\
\hline Time to export $(\log )$ & $\begin{array}{c}-0.117^{* *} \\
(0.045)\end{array}$ & $\begin{array}{c}-0.151^{* * *} \\
(0.048)\end{array}$ & & $\begin{array}{c}0.046 \\
(0.130)\end{array}$ & $\begin{array}{c}-0.031 \\
(0.141)\end{array}$ & \\
\hline Time to export $(\log ) *$ Small Firm (dummy) & & $\begin{array}{c}0.278 * * * \\
(0.048)\end{array}$ & & & $\begin{array}{c}0.634 * * * \\
(0.122)\end{array}$ & \\
\hline Time to export $(\log ) *$ Small Size & & & $\begin{array}{c}0.130 * * * \\
(0.042)\end{array}$ & & & $\begin{array}{c}0.610 * * * \\
(0.117)\end{array}$ \\
\hline Time to export $(\log ) *$ Medium Size & & & $\begin{array}{c}-0.044 \\
(0.043)\end{array}$ & & & $\begin{array}{c}0.188 \\
(0.132)\end{array}$ \\
\hline Time to export $(\log ) *$ Big Size & & & $\begin{array}{c}-0.313 * * * \\
(0.069)\end{array}$ & & & $\begin{array}{c}-0.365^{* *} \\
(0.178)\end{array}$ \\
\hline Distance $(\log )$ & $\begin{array}{c}-0.098 * * * \\
(0.022)\end{array}$ & $\begin{array}{c}-0.097 * * * \\
(0.022)\end{array}$ & $\begin{array}{c}-0.097 * * * \\
(0.022)\end{array}$ & $\begin{array}{l}-0.066 \\
(0.068)\end{array}$ & $\begin{array}{l}-0.064 \\
(0.068)\end{array}$ & $\begin{array}{l}-0.064 \\
(0.068)\end{array}$ \\
\hline $\operatorname{Ln}($ tariff +1$)$ & $\begin{array}{l}-0.186 \\
(0.136)\end{array}$ & $\begin{array}{l}-0.191 \\
(0.136)\end{array}$ & $\begin{array}{l}-0.206 \\
(0.136)\end{array}$ & $\begin{array}{c}0.144 \\
(0.342)\end{array}$ & $\begin{array}{c}0.134 \\
(0.343)\end{array}$ & $\begin{array}{c}0.102 \\
(0.343)\end{array}$ \\
\hline Import Share & $\begin{array}{c}0.205 \\
(0.202)\end{array}$ & $\begin{array}{c}0.214 \\
(0.202)\end{array}$ & $\begin{array}{c}0.212 \\
(0.202)\end{array}$ & $\begin{array}{l}1.591^{* *} \\
(0.704)\end{array}$ & $\begin{array}{l}1.612^{* *} \\
(0.702)\end{array}$ & $\begin{array}{l}1.608^{* *} \\
(0.707)\end{array}$ \\
\hline Per Capita GDP (log) & $\begin{array}{l}0.032^{*} \\
(0.019)\end{array}$ & $\begin{array}{l}0.033^{*} \\
(0.019)\end{array}$ & $\begin{array}{c}0.032 \\
(0.019)\end{array}$ & $\begin{array}{l}0.102 * * \\
(0.044)\end{array}$ & $\begin{array}{l}0.102 * * \\
(0.044)\end{array}$ & $\begin{array}{l}0.100^{* *} \\
(0.044)\end{array}$ \\
\hline Contiguity & $\begin{array}{c}0.190^{* * *} \\
(0.049)\end{array}$ & $\begin{array}{c}0.194 * * * \\
(0.048)\end{array}$ & $\begin{array}{c}0.201 * * * \\
(0.047)\end{array}$ & $\begin{array}{c}0.547^{* * *} \\
(0.181)\end{array}$ & $\begin{array}{c}0.557 * * * \\
(0.179)\end{array}$ & $\begin{array}{c}0.572 * * * \\
(0.180)\end{array}$ \\
\hline $\operatorname{Ln}(T U V)$ & $\begin{array}{c}0.027^{* * *} \\
(0.008)\end{array}$ & $\begin{array}{c}0.027^{* * *} \\
(0.008)\end{array}$ & $\begin{array}{c}0.027 * * * \\
(0.008)\end{array}$ & $\begin{array}{c}0.089 * * * \\
(0.025)\end{array}$ & $\begin{array}{c}0.090 * * * \\
(0.025)\end{array}$ & $\begin{array}{c}0.090 * * * \\
(0.025)\end{array}$ \\
\hline Observations & 463,384 & 463,384 & 463,384 & 463,384 & 463,384 & 463,384 \\
\hline R-squared & 0.066 & 0.067 & 0.070 & 0.040 & 0.042 & 0.044 \\
\hline Number of $\mathrm{i}$ & 92,338 & 92,338 & 92,338 & 92,338 & 92,338 & 92,338 \\
\hline
\end{tabular}

Standard errors are clustered within destination country in all estimation.

Dependent variables always in log.

All regressions include firm fixed effects.

$* * * p<0,01 ; * * p<0,05 ; * p<0,1$. 
Table A15 - Estimations using the number documents to export as a proxy for the trade cost.

\begin{tabular}{|c|c|c|c|c|c|c|}
\hline & \multicolumn{3}{|c|}{ Number exported products } & \multicolumn{3}{|c|}{ Export per product } \\
\hline & (1) & (2) & (3) & (4) & (5) & (6) \\
\hline Estimation Method & OLS & OLS & OLS & OLS & OLS & OLS \\
\hline N. Documents (log) & $\begin{array}{c}-0.087^{* *} \\
(0.038)\end{array}$ & $\begin{array}{c}-0.105^{* * *} \\
(0.039)\end{array}$ & & $\begin{array}{l}-0.104 \\
(0.090)\end{array}$ & $\begin{array}{l}-0.140 \\
(0.096)\end{array}$ & \\
\hline N. Documents (log)*Small Firm (dummy) & & $\begin{array}{c}0.138 * * * \\
(0.026)\end{array}$ & & & $\begin{array}{c}0.266 * * * \\
(0.078)\end{array}$ & \\
\hline N. Documents $(\log ) *$ Small Size & & & $\begin{array}{c}0.032 \\
(0.041)\end{array}$ & & & $\begin{array}{c}0.126 \\
(0.084)\end{array}$ \\
\hline N. Documents $(\log ) *$ Medium Size & & & $\begin{array}{l}-0.051 \\
(0.037)\end{array}$ & & & $\begin{array}{l}-0.055 \\
(0.091)\end{array}$ \\
\hline N. Documents $(\log ) *$ Big Size & & & $\begin{array}{c}-0.193^{* * * *} \\
(0.047)\end{array}$ & & & $\begin{array}{c}-0.276^{* *} \\
(0.117)\end{array}$ \\
\hline Distance (log) & $\begin{array}{c}-0.104^{* * *} \\
(0.021)\end{array}$ & $\begin{array}{c}-0.103^{* * *} \\
(0.021)\end{array}$ & $\begin{array}{c}-0.104^{* * *} \\
(0.021)\end{array}$ & $\begin{array}{l}-0.066 \\
(0.066)\end{array}$ & $\begin{array}{l}-0.065 \\
(0.066)\end{array}$ & $\begin{array}{l}-0.066 \\
(0.067)\end{array}$ \\
\hline $\operatorname{Ln}($ tariff +1$)$ & $\begin{array}{l}-0.200 \\
(0.137)\end{array}$ & $\begin{array}{l}-0.212 \\
(0.139)\end{array}$ & $\begin{array}{l}-0.227 \\
(0.137)\end{array}$ & $\begin{array}{c}0.222 \\
(0.355)\end{array}$ & $\begin{array}{c}0.197 \\
(0.357)\end{array}$ & $\begin{array}{c}0.175 \\
(0.357)\end{array}$ \\
\hline Import Share & $\begin{array}{c}0.279 \\
(0.206)\end{array}$ & $\begin{array}{c}0.291 \\
(0.208)\end{array}$ & $\begin{array}{c}0.299 \\
(0.211)\end{array}$ & $\begin{array}{l}1.548^{* *} \\
(0.692)\end{array}$ & $\begin{array}{l}1.572^{* *} \\
(0.694)\end{array}$ & $\begin{array}{l}1.585^{* *} \\
(0.704)\end{array}$ \\
\hline Per Capita GDP (log) & $\begin{array}{c}0.018 \\
(0.018)\end{array}$ & $\begin{array}{c}0.018 \\
(0.018)\end{array}$ & $\begin{array}{c}0.017 \\
(0.018)\end{array}$ & $\begin{array}{c}0.056 \\
(0.041)\end{array}$ & $\begin{array}{c}0.055 \\
(0.040)\end{array}$ & $\begin{array}{c}0.053 \\
(0.041)\end{array}$ \\
\hline Contiguity & $\begin{array}{c}0.208 * * * \\
(0.048)\end{array}$ & $\begin{array}{c}0.210 * * * \\
(0.047)\end{array}$ & $\begin{array}{c}0.213^{* * *} \\
(0.046)\end{array}$ & $\begin{array}{c}0.553 * * * \\
(0.173)\end{array}$ & $\begin{array}{c}0.557 * * * \\
(0.172)\end{array}$ & $\begin{array}{c}0.561^{* * *} \\
(0.173)\end{array}$ \\
\hline Ln(TUV) & $\begin{array}{c}0.026 * * * \\
(0.008)\end{array}$ & $\begin{array}{c}0.026 * * * \\
(0.008)\end{array}$ & $\begin{array}{c}0.027^{* * *} \\
(0.008)\end{array}$ & $\begin{array}{c}0.090 * * * \\
(0.024)\end{array}$ & $\begin{array}{c}0.091 * * * \\
(0.024)\end{array}$ & $\begin{array}{c}0.092 * * * \\
(0.024)\end{array}$ \\
\hline Observations & 463,384 & 463,384 & 463,384 & 463,384 & 463,384 & 463,384 \\
\hline R-squared & 0.066 & 0.067 & 0.070 & 0.040 & 0.041 & 0.042 \\
\hline Number of $\mathrm{i}$ & 92,338 & 92,338 & 92,338 & 92,338 & 92,338 & 92,338 \\
\hline
\end{tabular}

Standard errors are clustered within destination country in all estimation.

Dependent variables always in log.

All regressions include firm fixed effects.

$* * * p<0,01 ; * * p<0,05 ; * p<0,1$.

Table A16 - Total export estimations. Robustness including low-corruption and ASYCUDA countries

\begin{tabular}{lcccccccc}
\hline \hline & \multicolumn{7}{c}{ Dep. Variable: Total export per firm (in log) } \\
\hline & $\begin{array}{c}\text { Information } \\
\text { Availability }\end{array}$ & $\begin{array}{c}\text { Advance } \\
\text { Ruling }\end{array}$ & $\begin{array}{c}\text { Appeal } \\
\text { Procedure }\end{array}$ & $\begin{array}{c}\text { Fees and } \\
\text { Charges }\end{array}$ & $\begin{array}{c}\text { Formalities } \\
\text { Document }\end{array}$ & $\begin{array}{c}\text { Formalities } \\
\text { Automation }\end{array}$ & $\begin{array}{c}\text { Formalities } \\
\text { Procedures }\end{array}$ & $\begin{array}{c}\text { Border agency } \\
\text { (Int. + ext.) }\end{array}$ \\
\hline TFI (log)*Small Size & $1.528^{* * *}$ & $0.918^{* * *}$ & $0.302^{* * *}$ & 0.234 & -0.077 & 0.117 & $0.290^{*}$ & -0.050 \\
& $(0.476)$ & $(0.183)$ & $(0.081)$ & $(0.260)$ & $(0.237)$ & $(0.296)$ & $(0.165)$ & $(0.273)$ \\
TFI (log)*Medium Size & $0.707^{*}$ & $0.500^{* *}$ & -0.135 & $0.430^{* *}$ & $0.565^{* *}$ & 0.281 & 0.145 & 0.429 \\
& $(0.371)$ & $(0.238)$ & $(0.159)$ & $(0.204)$ & $(0.237)$ & $(0.283)$ & $(0.195)$ & $(0.285)$ \\
TFI (log)*Big Size & -0.214 & -0.230 & -0.531 & $0.749^{*}$ & $1.205^{* * *}$ & 0.567 & -0.227 & 0.575 \\
& $(0.570)$ & $(0.493)$ & $(0.336)$ & $(0.426)$ & $(0.314)$ & $(0.447)$ & $(0.373)$ & $(0.432)$ \\
\hline Firm FE & yes & yes & yes & yes & yes & yes & yes & yes \\
Country Controls & yes & yes & yes & yes & yes & yes & yes & yes \\
\hline Observations & 320,192 & 293,626 & 301,317 & 307,566 & 319,910 & 319,965 & 316,389 & 247,162 \\
R-squared & 0.075 & 0.075 & 0.072 & 0.073 & 0.079 & 0.073 & 0.069 & 0.050 \\
Number of i & 77,106 & 73,743 & 76,157 & 75,771 & 77,076 & 77,095 & 76,447 & 70,550 \\
\hline
\end{tabular}

Standard errors are clustered within destination country.

All regressions include firm fixed effects and country controls.

$* * * p<0,01 ; * * p<0,05 ; * p<0,1$. 
Table A17 - Extensive margin estimations. Robustness including low-corruption and ASYCUDA countries

\begin{tabular}{lcccccccc}
\hline \hline & \multicolumn{7}{c}{ Dep. Variable: } & Number of exported products per firm (in log) \\
\hline & $\begin{array}{l}\text { Information } \\
\text { Availability }\end{array}$ & $\begin{array}{c}\text { Advance } \\
\text { Ruling }\end{array}$ & $\begin{array}{c}\text { Appeal } \\
\text { Procedure }\end{array}$ & $\begin{array}{c}\text { Fees and } \\
\text { Charges }\end{array}$ & $\begin{array}{c}\text { Formalities } \\
\text { Document }\end{array}$ & $\begin{array}{c}\text { Formalities } \\
\text { Automation }\end{array}$ & $\begin{array}{c}\text { Formalities } \\
\text { Procedures }\end{array}$ & $\begin{array}{c}\text { Border agency } \\
\text { (Int. + ext.) }\end{array}$ \\
\hline TFI (log)*Small Size & $0.454^{* * *}$ & $0.189^{* * *}$ & $0.087^{* * *}$ & 0.081 & 0.045 & 0.089 & -0.017 & -0.059 \\
& $(0.133)$ & $(0.055)$ & $(0.032)$ & $(0.077)$ & $(0.077)$ & $(0.089)$ & $(0.052)$ & $(0.070)$ \\
TFI (log)*Medium Size & $0.231^{* *}$ & $0.102^{*}$ & -0.002 & 0.071 & $0.207 * *$ & 0.084 & -0.030 & 0.041 \\
& $(0.106)$ & $(0.058)$ & $(0.033)$ & $(0.062)$ & $(0.077)$ & $(0.072)$ & $(0.051)$ & $(0.051)$ \\
TFI (log)*Big Size & -0.049 & -0.084 & -0.120 & 0.208 & $0.456^{* * *}$ & 0.228 & -0.107 & 0.051 \\
& $(0.169)$ & $(0.132)$ & $(0.082)$ & $(0.146)$ & $(0.112)$ & $(0.141)$ & $(0.096)$ & $(0.107)$ \\
\hline Firm FE & yes & yes & yes & yes & yes & yes & yes & yes \\
Country Controls & yes & yes & yes & yes & yes & yes & yes & yes \\
\hline Observations & 320,192 & 293,626 & 301,317 & 307,566 & 319,910 & 319,965 & 316,389 & 247,162 \\
R-squared & 0.063 & 0.056 & 0.060 & 0.059 & 0.068 & 0.062 & 0.059 & 0.040 \\
Number of i & 77,106 & 73,743 & 76,157 & 75,771 & 77,076 & 77,095 & 76,447 & 70,550 \\
\hline
\end{tabular}

Standard errors are clustered within destination country.

All regressions include firm fixed effects and country controls.

$* * * p<0,01 ; * * p<0,05 ; * p<0,1$.

Table A18 - Intensive margin estimations. Robustness including low-corruption and ASYCUDA countries

\begin{tabular}{lcccccccc}
\hline \hline & \multicolumn{7}{c}{ Dep. Variable: Firm export per product (in log) } \\
\hline & $\begin{array}{c}\text { Information } \\
\text { Availability }\end{array}$ & $\begin{array}{c}\text { Advance } \\
\text { Ruling }\end{array}$ & $\begin{array}{c}\text { Appeal } \\
\text { Procedure }\end{array}$ & $\begin{array}{c}\text { Fees and } \\
\text { Charges }\end{array}$ & $\begin{array}{c}\text { Formalities } \\
\text { Document }\end{array}$ & $\begin{array}{c}\text { Formalities } \\
\text { Automation }\end{array}$ & $\begin{array}{c}\text { Formalities } \\
\text { Procedures }\end{array}$ & $\begin{array}{c}\text { Border agency } \\
\text { (Int. + ext.) }\end{array}$ \\
\hline TFI (log)*Small Size & $1.073^{* * *}$ & $0.729^{* * *}$ & $0.215^{* * *}$ & 0.152 & -0.121 & 0.027 & $0.308^{* *}$ & 0.009 \\
& $(0.360)$ & $(0.132)$ & $(0.057)$ & $(0.204)$ & $(0.204)$ & $(0.223)$ & $(0.124)$ & $(0.224)$ \\
TFI $(\log ) *$ Medium Size & 0.475 & $0.398^{*}$ & -0.133 & $0.359^{*}$ & 0.357 & 0.197 & 0.176 & 0.388 \\
& $(0.288)$ & $(0.197)$ & $(0.134)$ & $(0.177)$ & $(0.217)$ & $(0.229)$ & $(0.168)$ & $(0.252)$ \\
TFI $(\log ) *$ Big Size & -0.165 & -0.146 & -0.410 & $0.541^{*}$ & $0.748^{* * *}$ & 0.339 & -0.120 & 0.523 \\
& $(0.428)$ & $(0.374)$ & $(0.259)$ & $(0.311)$ & $(0.250)$ & $(0.323)$ & $(0.303)$ & $(0.341)$ \\
\hline Firm FE & yes & yes & yes & yes & yes & yes & yes & yes \\
Country Controls & yes & yes & yes & yes & yes & yes & yes & yes \\
\hline Observations & 320,192 & 293,626 & 301,317 & 307,566 & 319,910 & 319,965 & 316,389 & 247,162 \\
R-squared & 0.044 & 0.047 & 0.042 & 0.043 & 0.045 & 0.042 & 0.040 & 0.031 \\
Number of i & 77,106 & 73,743 & 76,157 & 75,771 & 77,076 & 77,095 & 76,447 & 70,550 \\
\hline
\end{tabular}

Standard errors are clustered within destination country.

All regressions include firm fixed effects and country controls.

*** $p<0,01 ; * * p<0,05 ; * p<0,1$. 